\title{
単位図法とその適用に関する基礎的研究
}

\author{
正 員 石 原 藤 次 郎* \\ 正員高棹 珧 馬**
}

\section{FUNDAMENTAL RESEARCHES ON THE UNIT HYDROGRAPH METHOD AND ITS APPLICATION}

\author{
By Dr. Eng., Tojiro Ishihara, C. E. Member \\ and Takuma Takasao, C. E. Member
}

Synopsis : The basic principle of the unit hydrograph method assumes that there exists a linear relation between the discharge $Q(t)$ and the rainfall $r(t)$ expressed as

$$
Q(t)=\int_{-\infty}^{t} X(\tau) r(t-\tau) d \tau
$$

where $X(t)$ is the unit hydrograph given as a kernel of the linear integral equation.

Since this expression is obviously based on emperical relations, the hydraulic significance of the unit hydrograph method will be lost, unless a dynamical basis of the above expression is verified in the light of fluid mechanics.

Under these considerations, the present paper deals theoretically with the following two themes from a stand point of hydraulics.

1) Hydraulic significance of the fundamental principle of the unit hydrograph method.

2) The most preferable elements of the unit rainfall and the unit hydrograph, and estimation of errors due to the application of the unit hydrograph method.

The authors hope that the results derived in the present paper will bring effective procedures to solve important practical problems such as the range of applicability of the unit hydrograph method or the synthetic unit hydrograph and so on.

要 旨 本論文は, 山間地流域に括ける雨水の挙動を水理学に究明して, 単位図法の力学的意義を明 確汭すととるに，単位降雨招よび単位図の内部的の機構を論じて，それらの最も妥当な形を求め，さ らに単位図法適用にともなろ誤差関係を明らかとしたものであつて，兄られた成果は本質的に普遍性を もつものといつてよい。これらは経験的に発展してきた単位図法に招いて論議の対象となつている単位 降雨括よび単位図の最適要素, 単位図法の適用限界, さらには総合単位図といつた問題值結したもの であり，単位図法に関する諸問題の解決に寄与するところが少なくないであろう。

目次

\section{1. はしがき}

2. 雨水流出の水理機構
（1）雨水の伝播と流量に関する基礎方程式
（2）二，三の流出特性と降雨招よび流域の特 性との関係

3. 単位図法の力学的意義と流出現象の線型性
(1) 単位図法の力学的意義
（2）流出現象の線型性

4. 単位図法の精度之降雨および流域の諸特性之 の関係

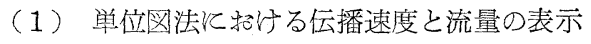

（2） $x_{0} \sim t$ 面飞和忊る $\alpha_{t}$ の変動
（3） $\alpha_{t}$ の変動と流下距離招よび降雨継続時 間との関係

（4）降雨の場所的分布と単位図法の精度

（5）単位図法の精度についての総括

5. 流出機構の分類と単位図法による最大流量の 適合条件
(1) $\alpha_{t}$ の平均化
（2）流出機構の差異による分類
（3）単位図法に上る流出解析の適合条件

\section{6. 単位降雨の要素}

(1) 小流域の場合 $\left(t_{u}<t_{c}, t_{d}>t_{c}\right)$
(2) 大流域の場合 $\left(t_{u}<t_{c}, t_{d}<t_{c}\right)$ 
（3）流域の大小と単位降雨要素との関係

\section{7. 単位図の要素}

（1）最大流量の遅れの時間

（2）小流域に扔ける単位図の要素

（3）大流域に招ける単位図の要素

（4）流域の大小と単位図要素との関係

\section{8. 単位図法の適用誤差}

（1）最大流量飞関する単位図法誤差

（2）流出量曲線全体に関する単位図法誤差

（3）流域の大小と単位図法誤差との関係

9. むすび

参洘文献

\section{1.はしがき}

1932 年 Sherman が三つの線型仮説飞もとづく単位図法を提案して以来，単位図法はとの簡明な実用性によつ て，山間地流域に和ける流出解析法として広く用いられるようになつた。

単位図法の基礎的原理は, 流量 $Q(t)$ と降雨 $r(t)$ の間飞,

$$
Q(t)=\int_{-\infty}^{t} X(\tau) r(t-\tau) d \tau
$$

といろ線型関係が成立するものとし，この線型積分方程式の核として，単位図 $X(t)$ を与えるということである。 これは，山間地流域に括ける流出現象のように，流れの場が極端に不均一であつて，しかも任意性にとむ現象に 対しては, 古典的な力学的取り拔いが困難かあるいは不可能であることに着目し，一種の確率論的思考をも含ん でいることを意味しているのでめつて，簡明な実用性という面からだけではなく，方法論的とも卓抜した理念を 内蔵している点に注目しなければならない。

山間地流域に特ける雨水の挙動は，明らか飞一つの力学系を構成しているが，雨水の微小な実質部分注目す

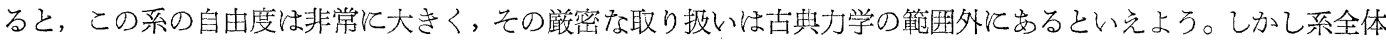
の各時刻に挪ける微視状態を完全に知ること，すなわち系全体を完全に力学的記述することは，実際上われわ れの関心をひくるのではないし，またその必要もないのであつて，観測地点に打活る現象の巨視的な知識さ兄えら れればよいのである。単位図法の基礎としての上述の線型積分方程式は，力学的法則によるものではなく，全く経 験的事実にもとづくものであることが明白であり，これが原理的に正しければ，系の各時刻の微視状態を力学的に 追跡しなくとも，必要な知識が党られるということであつて，単位図法の力強さは実にこの点にあるのである。

しかしながら，雨水の流出が明らかて力学的事象である以上，上述の経験的事実にもとづく法則の力学的な妥 当性が保証されなければ，単位図法の意義が失われることはいうまでもない。こうした意味から，単位図法の論 議の対象は，つぎの点につくされているといえよう。

1. 単位図法の力学的意義を明確にすること。

2. るし単位図法の基礎原理が力学的法則とはずれているとすれば，単位図法の基礎となる単位降雨扔よび単 位図には，われわれの問題とする対象に応じて，最も望ましい形があるはずであるから，その形を求めることが 必要になり，さらにそうした単位降雨㧍よび単位図による単位図法を適用するときの誤差関係を知らねね゙ならな い。このためには，単位降雨あるい愔位図のるつ内部的な機構孛明らかとすることが必要である。

以上の二つの主題は，現在単位図法で論議の対象となつていろ単位降雨呿よび単位図の最適要素，単位図法の 適用限界, さらには総合単位図といつた諸問題に直結して招り, これらの主題を解決することにょつて, 単位図 法に関する問題点が括のずから解明されるであるう。

この研究は, 以上の見地にたつて, 山間地流域に怙ける雨水の挙動を水理学的に一貫して究明しながら, 上述 の二つの主題の解明を試みたものである。

\section{2. 雨水流出の水理機構}

山間地流域飞括ける雨水の流出現象は，降雨を供給源とし流域を媒体とした雨水の運動現象である。ところが 供給源である降雨は，きわめて任意性にとんでいて，その時間的場所的分布については，偶然現象と考吾ざるを えないことが多い。さらに流出の媒体，すなわち雨水運動の場である流域は，大きく分けて面的特性をるつ斜面 と線的特性をるつ流路の二つの要素で構成されたものと考兄られるが，この二つの要素の分布と性状ははなはだ しく不均一である。こうした意味から，流出現象は不均一場に、抢ける偶然性で特徽づけられた雨水の運動現象と いえるのであつて，雨水流出の一般法則を理論的に求めることの極度の困難さは，この流出現象の性格にもとつ くものといえよう。

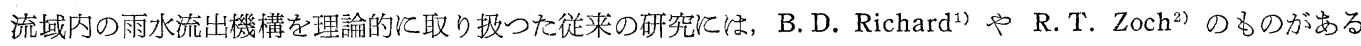
が，前提として揓いた仮定があ末りと単純かつ大担にすぎるようであり，また単と定性的な意味からも疑問の点 
があつて, 力学的な論拠をるつるのとは考光られない。

ここでは, 単位図法関する論議の基礎とするために, 雨水流出の水理学的諸関係を明らかにするが，さらに 十分な理論の厳密な組立ては, 流出現象の偶然的特性を考慮した確率論的思考を導入してはじめて可能になるる のと思われる。

な括, 以下に扔いては降雨の場所的分布括よび雨水の損失現象については考慮せず，もつぱら有効降雨を対象と して，地表面流出だけを取り扱うことにする。

\section{(1) 雨水の伝播と流量に関する基礎方程式}

運動現象を力学的に明らかにしようとする場合，一般微分方程式が用いられるが，その基礎として微視的平 衡といろ概念があるから，不均一場と扔いては，艺の場の特性として平均量をとつて子妥当である場合飞のみ， 微分方程式にもとづく理論の組立てが許される。

流出現象に执いては，運動の場は流域であって，その特性として重要なるのは，重力の効果を表わす勾配と摩 擦効果を表わす粗度とである。流域は斜面と流路の二つの場から構成されているが，それぞれの場の特性，こと

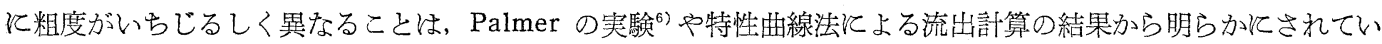
る。こうした意味で, 流出現象の力学的取り扱いに执いては，斜面と流路とを等価な流れの場として一様化する ことができない。したがつて，流域を斜面と流路との二つの場と分けることは，流域を単純化する極限と考光ら れる。斜面あるいは流路自体の諸因子がまたはなはだしく不均一であるが，それぞれと物ける流れの機構には本

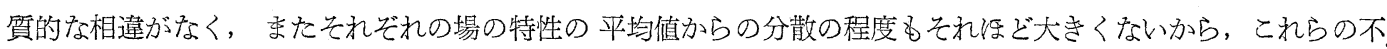
均一量を平均量湾換して処理することは, 十分許されるであるう。

以上の立場に立つて，斜面括よび流路の二つの流れの場について，それぞれに㧍ける雨水流出の水理機構を考 察しょう。まず，一般断面流路に扔いて，時間的に変動する横からの流入がある場合，流れが等流江近いものと 仮定すれば，運動方程式と連続式はとれぞれつぎのように表わされる。

$$
A=f_{n}(Q)=K Q^{p} \text {, }
$$

$\partial A / \partial t+\partial Q / \partial x=q(t), \ldots$

ここに, $A$ は流水断面積, $Q$ は流量, $q(t)$ ほ流路単位長当りの横から流入量 (時間の任意関数), $x$ は距離, $t$ は 時間であつて, 流れが Manning の抵抗法則としたがうものとすると，

$$
K=\left\{n(\sin \theta)^{-1 / 2} K_{1}^{2 / 3}\right\}, \quad p=3 /(2 z+3)
$$

である。この場合, $n$ は流路の粗度係数, $\sin \theta$ は流路の勾配, $K_{1}$ 招よび $z$ は径深 $R$ と流水断面積 $A$ との関係 が $R=K_{1} A^{z}$ と和けるとした場合の常数である。

(2.1) 招よび (2.2) 式加, 特性方程式として,

$$
\frac{d x}{1}=\frac{d t}{d A / d Q}=\frac{d Q}{q(t)}
$$

が与光られ，さらに (2.1) 式を用いて変形すれば,

$$
\frac{d x}{1}=\frac{d t}{p K Q^{p-1}}=\frac{d Q}{q(t)}
$$

となる。したがつて, (2.3) 捛よび (2.4) 式から, 特性曲線

$$
\frac{d x}{d t}=\frac{d Q}{d A}=\frac{Q^{1-p}}{p K}
$$

の上で，次式が成立するととになる。

$$
Q=\left\{\int_{\tau}^{t} q(t) d t / K\right\}^{1 / p}+Q(\xi, \tau), \quad Q=\int_{\xi}^{x} q(t) d x+Q(\xi, \tau),
$$

ここに, $Q(\xi, \tau)$ は流量の初期招よび境界条件を示するので, 特性曲線の出発する場所的, 時間的位置 $\xi, \tau$ 飞招 ける流量を表わしている。

いま，(2.6）式を(2.5) 式沉入れると, 特性曲線の微分方程式として,

$$
\frac{d x}{d t}=\frac{1}{p K}\left[\left\{\int_{\tau}^{t} q(t) d t / K\right\}^{1 / p}+Q(\xi, \tau)\right]^{1-p}
$$

がえられ、これを積分してつぎの特性曲線式が導かれる。

$$
x=\frac{1}{p K} \int_{\tau}^{t} d s\left[\left\{\int_{\tau}^{s} q(z) d z / K\right\}^{1 / p}+Q(\xi, \tau)\right]^{1-p}+\xi
$$

(2.6), (2.8) の両式の関係を数学的に説明すれば， $Q-x-t$ の三次元空間に括いて, 解㟧るいは積分曲面に含 
末れる曲線を $x-t$ 面と投影したものが特性曲線式 (2.8) であり, したがつてこの上で (2.6) 式といろ $Q$ の関 係が成立するのである。な挌，Qの一般解は，(2.3）招上び (2.4) 式から独立な二つの第一積分を求めることに よつて,

$$
Q=F\left[Q-\left\{\int q(t) d t / K\right\}^{1 / p}, x-(1 / p K) \int Q^{1-p} d t\right]=0
$$

で表わされる任意関数である。

つぎに, 斜面の場合には流れを近似的に二次元流と考光ることができ, 横からの流入量㤃有効降雨強度 $r(t)$, 斜 面の流量は $q$ で表わせばよい。委た斜面流の初期捛よび境界条件は0としてよいから,流路の場合の (2.1) , (2.2), (2.6) 特よび (2.8) 式対応するものとして, つぎの諸式が壳られる。ここに, ダッシュは斜面上に和ける值を 示したものである。

$$
\begin{aligned}
& h^{\prime}=K^{\prime} q^{p^{\prime}} \text {, } \\
& \partial h^{\prime} / \partial t+\partial q / \partial x^{\prime}=r(t) \text {, } \\
& q=\left\{\int_{\tau}^{t} r(t) d t / K^{\prime}\right\}^{1 / p^{\prime}}, \quad q=\int_{\xi}^{x \prime} r(t) d x^{\prime}, \\
& x^{\prime}=\frac{1}{p^{\prime} K^{\prime 1 / p^{\prime}}} \int_{\tau}^{t} d s\left\{\int_{r}^{s} r(z) d z\right\}^{1 / p^{\prime-1}}+\xi^{\prime} .
\end{aligned}
$$

な扮，斜面上の流れが Manning の抵抗法則としたがうるのとすると，つぎのようになる。

$$
K^{\prime}=\left(n^{\prime} / \sqrt{\sin \theta^{\prime}}\right)^{1 / p^{\prime}} ; \quad p^{\prime}=3 / 5 \text {. }
$$

上飞党られた (2.8) 扣よび (2.12) 式は雨水の伝播状態を表和す式であつて, (2.6) 呿よび (2.11) 式怯播 式上で成立する流量の関係を示するのである。これらの諸式は以下に括ける考察の基礎となるるのであるが，こ

\section{図一 2.1 矩形模型流域図}

Fig. 2.1 Schematic diagram of a rectangular model basin.

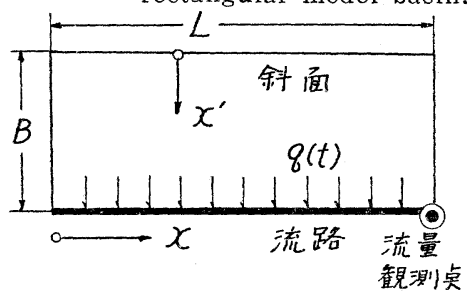

\section{こでそれらの物理的意義を説明して抢く。}

流路への流入量は時閵的に変動するが，場所的には一様と仮定してい るから, 図一2.1 の上ら飞片側飞一本の流路をもつ矩形流域（あるいは 平行四辺形流域）について考光ていることになる。流路が流域の中を流 れている場合も, 取り挺いは全く同様でめつて, 両斜面からの流入量を 合わせて $q(t)$ とすればよい。座標は斜面ではとの上流端から雨水の平 均的な流下径路に沿つてとり, 流路ではとの上流端から下流端に向つて とつて, 斜面上の流下距離を $B$ とし, 流路長を $L$ とする。な枌, こうし

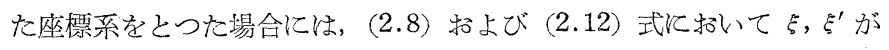

図-2.2 雨水擾乱の伝播状態および伝播式亡流量式との関係

Fig. 2.2 Schematic diagram showing propagation states of rainfall disturbance and relations between equations of propagation and discharge.

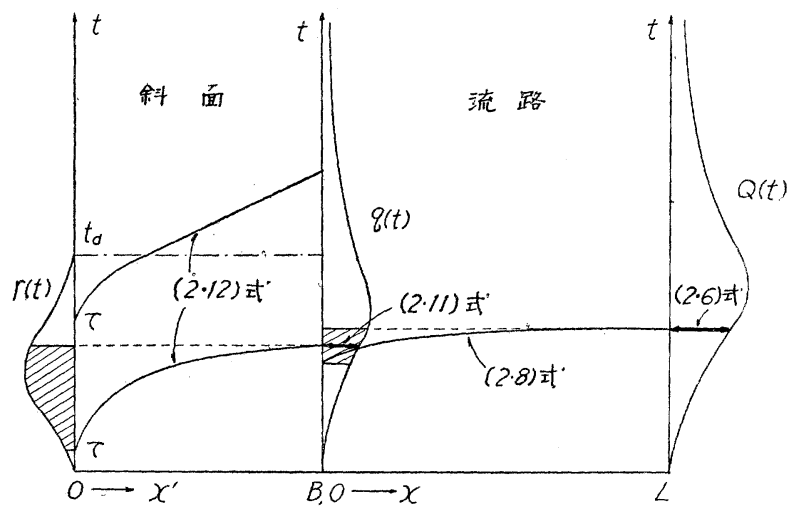

\section{ともに0となるはずである。}

斜面上流端治まつた雨水の伀播が流路端 Bに達して流路に流入乙, 流路下流端の観測 点晌つて流下していく過程を示すと, 図一 2.2 のと招りである。斜面上抢よび流路内の 雨水の伝播状態を表わす各特性曲線は(2.12) 呿よび (2.8) 式で与兄られ，(2.11）招よび (2.6) 式は流路端の流入量和上び観測点の流 量にはそれぞれの伝播時間内の降雨扮よび流 入量が関与することを示し, 図涂線を施し た部分で表わされる。な招, 斜面招よび流路 の特性を示鸟四つの量 $p^{\prime}, K^{\prime}, p, K$ は, そ れぞれの遅滞效果を表わしていることにな る。

最後に，運動方程式として Manning の抵

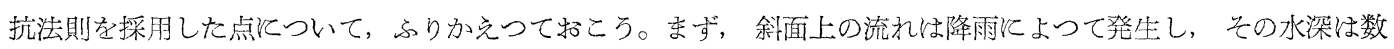
$\mathrm{mm}$ ない数 $\mathrm{cm}$ であつて, 土壤表面を薄く扔招つて流下する。こうした流れは, 薄尿流 (Thin sheet flow), 浅 水流 (Shallow flow), 地表流 (Overland flow) あるい怟低流 (Low flow) といつた名称でよばれている。し かし，流域斜面の特性である植物による被覆と極端な不均一性とを考慮している点に颃いて，流域斜面流の定義 としては, Palmer の名づけた低水流が妥当なものと考光られる。 
土猿表面を薄く招招つて流れる流れについては，従来から多くの研究があり，そのほとんどが流れの性格を Reynolds 数によつて判断しているようであるが，層流から乱流に移る限界 Reynolds 数としては，310，300〜

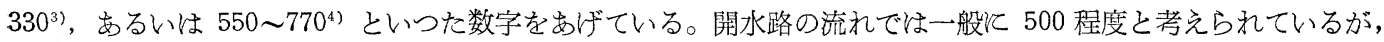
上揭の值は一例を除いてはそれよりかなり小さく，粗度の増加沈応じて限界 Reynolds 数が減少するという岩坦 博士の実験結果らと較べて, 興味の深いこととい方よう。いずれにしても, 流域斜面流でも層流と乱流の二つの領 域が存在することになるが，斜面の極度の不均一さを考慮すれば，斜面流全体にわたつて乱流として取り扱う方 が適当と思われる。このことは，Palmer が草地に招ける大規模な実験 ${ }^{6}$ によつて，流量が水深の $5 / 3$ 乗飞比例 し，したがつて流れが乱流でしかも Manning の抵抗法則に従うことを見出している点からる，十分妥当なるの といえよう。

また流域斜面流では，摩擦の効果が卓越するものと考兄られるから，慣性項，水面勾配の変化率，降雨による 流入括よび浸透による流出などが流れの運動状態飞扔よぼす影響は考慮しなかつた。

流路に招ける運動方程式として, Manning の抵抗法則を選ぶことは, 洪水流の頂部付近に招いて近似的許さ れると過ぎないが，流出現象で工学的に最も重要な特性が最大流量にあることと，次節で述べるように流出関係

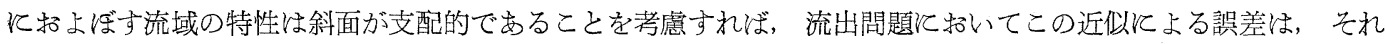
ほど問題とならないるのと考学られる。

以上の仮定や近似は, 未石助教授 ${ }^{7}$ が特性曲線法を適用し, 大戸川招よび由良川の出水を解析して良好な結果を 光た場合に用いたものと全く同一であることを付記して招く。

\section{(2) 二, 三の流出特性と降雨および流域の特性との関係}

ここでは前節で求めた基礎方程式を用いて，二，三の重要な流出特性と降雨呿よび流域の諸特性との関係を明 らかてするが，これらの成果は後に述べる単位図法に関する考察の基礎を与兄るものである。

（a） 雨水擾乱の伝播時間について ここでいう伝播時間は，降雨という流入によつて生じた擾乱の伝播につ いてであつて，水粒子そのものの伝播についてではない。物理的には，一種の波動の移行として理解できよう。

二次元流飞招いて，流れが Manning の抵抗法則飞従うとし，かつ横からの流出入が運動状態に招よぼす影響 を無視すれば, 雨水擾乱の伝播速度 $d x / d t$ と平均流速 $u$ の間には,

$$
d x / d t=5 u / 3
$$

の関係があり，流れが Chézy の抵抗法則従うとすれば，上式の右迅は $3 u / 2$ となる。一方，(2.5) 式から

$$
d x / d t=d Q / d A
$$

をうるが，これは洪水流頂部の伝播速度を表わす Kleitz-Seddon の法則と形式的飞一致する。ここでいう擾乱の 伝播は，横から流入のない有堤部に和ける洪水流の伝播とは多少意義を異にするが，大体飞括いて似たものと考 えてよい。しかし数学的にはその意義は明確であつて, $d x / d t$ は (2.1) 招よび (2.2) 式（あるいは (2.9), (2. 10) 式) からえられる積分曲面 $Q$. (あるいは $q$ ) 飞含まれる曲線を $x-t$ 面に投影して求めた特性曲線の接線であ り, また前節で求めた特性曲線式 (2.8) 式（あるいは(2.12)）の上で (2.6) 式 (あるいは (2.11)式) 方成立し

図一2.3 流域斜面の伝播状態を表わす特性 曲線 $\left(\boldsymbol{t}_{d}>\boldsymbol{t}_{B} \cdot \boldsymbol{r}\right)$

Fig. 2.3 Characteristic curves showing propagation states of rainfall disturbance on side slope sur-

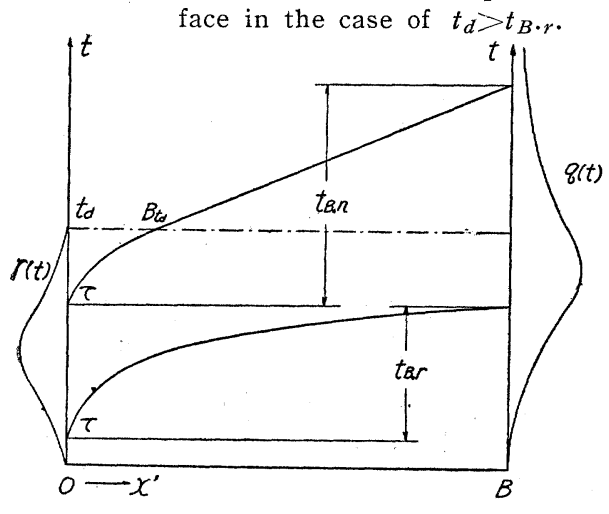

て, 流量が関係づけられるのであるから, 流出関係でいう雨 水の流達時間という概念は, ここでいう擾乱の伝播時間とい う意味で考光られなければならない。したがつてRichard あ るいは Zoch などが流達時間を流速から定義づけているの は，妥当なものとは考光られない。こうした意味で以下に述 べる伝播時間は, 水理学的な意義での雨水の流達時間を表現 するすのである。

流域内に降つた雨は, 斜面上を流れて流路に流入乙, さら そ流路内を流れて観測点飞到達するから, まず流域斜面上の 流れの伝播時間 $t_{B}$ そついて考兄る。この場合，伝播時間 $(t-\tau)$ と水文量との関係は，(2.12) 式によつて次式のよう に表わされる。

$$
p^{\prime} B K^{\prime^{1 / p^{\prime}}}=\int_{\tau}^{t} d s\left\{\int_{\tau}^{s} r(z) d z\right\}^{1 / p^{\prime \prime-1}} .
$$

斜面上の流れは, 降雨がある場合とない場合とで機構を異 にするから, 最初に降雨継続時間中に雨水擾乱の伝播が斜面 
全体を扮招うような場合の伝播時間 $t_{B \cdot r}$ そついて考光よう。こうろ場合には, (2.13) 式の右辺の積分は, 伝 播時間内の平均降雨強度 $r_{m}$ を用い, つぎのよう福き直される。

$$
\begin{aligned}
& \int_{\tau}^{t} d s\left\{\int_{\tau}^{s} r(z) d z\right\}^{1 / p^{\prime}-1}=\int_{\tau}^{t}\left[r_{m}(t-\tau)+\left\{R(t)-R(\tau)-r_{m}(t-\tau)\right\}\right]^{1 / p^{\prime}-1} d t, \\
& \text { ただし, } \quad R(t)=\int_{0}^{t} r(t) d t, \quad r_{m}=\int_{t_{B \cdot r}} r(t) d t / \int_{t_{B \cdot r}} d t
\end{aligned}
$$

上式治ける右辺被積分項の第二項

$$
\{R(t)-R(\tau)\}-r_{m}(t-\tau)=N(t, \tau)
$$

図一2.4 降雨の時間的分布形状亡 $\boldsymbol{N}(\boldsymbol{t}$, च) との関係

Fig. 2.4 Relation between rainfall hourly distribution and $N(t, \tau)$

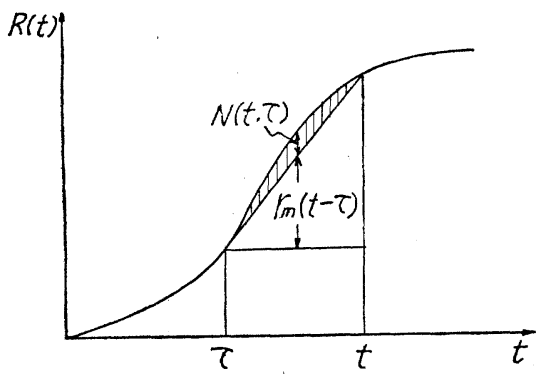

は, 伝播時間内に括ける降雨の時間分布形状が伝播時間に招よぼす効 果を示するのであつて，その積分は図一2.4 亿示す影線部分に相当 する。この $N(t, \tau)$ は, 伝播時間内の降雨 $r(t)$ の $t$ 亿関する一次微 係数の正負认よつて符命がかわり，つぎの関係がある。

$$
d r / d t \gtreqless 0 \text { に対し, } N(t, \tau) \risingdotseq 0 \text {. }
$$

しかしいずれにしても， $N(t, \tau)$ は被積分項の第一項の平均降雨強 度項 $r_{m}(t-\tau)$ 飞較ベていちじるしく小さいから，(2.14) 式は十分 の近似度をるつて,

$$
p^{\prime} B K^{1^{1 / p^{\prime}}}=\int_{0}^{t-\tau}\left(r_{m} t\right)^{1 / p^{\prime-1}} d t
$$

と表わすことができる。これは容易に積分できるから，

$$
t_{B \cdot r}=t-\tau=K^{\prime} B^{p^{\prime}} / r_{m}{ }^{1-p^{\prime}}
$$

として, 伝播時間とその間の平均降雨強度招よび流域特性との関係式

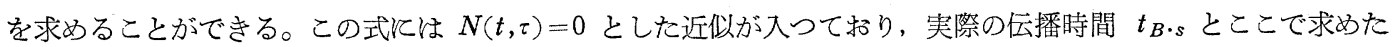
伝播時間 $t_{B} \cdot r$ との間には, (2.16) 式の関係からつぎのような性質がある。

$$
d r / d t \gtreqless 0 \text { 亿対し, } t_{B \cdot r} \leqq t_{B \cdot s}
$$

したがつて伝播時間内の降雨の平均強度が等しくても, 降雨曲線の変化率 $d r / d t$ とよつて, 伝播時間が影響さ れることになる。一般的には，降雨強度が増加していく部分の伝播時間が減少していく部分のそれよりも大きい とい方るが, 降雨の形状項 $N(t, \tau)$ は平均強度項 $r_{m}(t-\tau)$ 飞比していちじるしく小さいから, 降雨の分布形状の 効果を無視した (2.18) 式の精度は十分高いといつてよい。な扮, 後に述べる最大流量の発生条件から, 最大流 量を発生する伝播の出発時刻 $\tau_{p}$ と到達時刻 $t_{p}$ との間には, 降雨のピークをはさんで $r\left(\tau_{p}\right)=r\left(t_{p}\right)$ という関係 があるから， $\tau_{p}$ と $t_{p}$ の間の降雨の分布形状の影響が相殺されて， $N(t, \tau)$ の積分值は怯とんど 0 と等しくなるは ずである。

つぎに斜面上流端から出発した雨水の擾乱が流路に到達する途中で降雨が終つた場合について，その伝播時間 $t_{B \cdot n}$ の関係を考えよう。この場合 図一2.3 飞示すように, $\tau$ から出発した雨水が降雨終了時刻 $t_{d}$ まで飞到達し た距離を $B_{t d}$ で表わすと，降雨の分布形状の効果を無視して，(2.17) 式からつぎの関係がえられる。

$$
\left.\begin{array}{l}
p^{\prime} B_{t d} K^{1 / p^{\prime}}=\int_{0}^{t_{d}-\tau}\left(r_{m} t\right)^{1 / p^{\prime-1}} d t=p r_{m^{1 / p^{\prime-1}}\left(t_{d}-\tau\right)^{1 / p^{\prime}},}^{t_{d}} \\
\text { ただし, } r_{m}=\int_{\tau}^{t_{d}} r(t) d t / \int_{\tau}^{t_{d}} d t .
\end{array}\right\}
$$

一方, $B_{t_{d}}$ に括ける层播速度は, (2.12) 式から

$$
\left(\frac{d x^{\prime}}{d t}\right)_{t=t d}=\frac{1}{p^{\prime} K^{\prime 1 / p^{\prime}}}\left\{\int_{\tau}^{t} d r(t) d t\right\}^{1 / p^{\prime-1}}=\frac{\left\{r_{m}\left(t_{d}-\tau\right)\right\}^{1 / p^{\prime-1}}}{p^{\prime} K^{\prime 1 / p^{\prime}}}
$$

となる。したがつて $B_{t d}$ から流路端 $B$ まで要する伝播時間 $\left(t-t_{d}\right)$ は，つぎのようと計算される。

$$
t-t_{d}=\frac{B-B_{t d}}{\left(d x^{\prime} / d\right) t=t a}=\left(B-B_{t d}\right) \frac{p^{\prime} K^{\prime 1 / p^{\prime}}}{\left\{\gamma_{m}\left(t_{d}-\tau\right)\right\}^{1 / p^{\prime-1}}}
$$

(2.21) と (2.22) の両式から $B_{t d}$ を消去して整理すると,

$$
\left(t_{d}-\tau\right)^{1 / p^{\prime-1}}\left\{\left(t-t_{d}\right)+p^{\prime}\left(t_{d}-\tau\right)\right\}=p^{\prime} B K^{\prime 1 / p^{\prime}} \mid r_{m^{1 / p^{\prime}-1}}
$$

となり, $\tau$ 招よび $t$ と降雨, 流域の特性との間係が求められる。この場合の伝播時間 $t_{B \cdot n}=t-\tau$ を上式から解 析的に求めることは, 一般的には困難でめるが, 流入量 $q(t)$ のピークの起時は 図-2.5飞示すように $\tau=0$ の擾 乱が到達する時刻と $t_{d}$ との間にある。したがつて工学的な重要性に着目すれば， $\tau=0$ の場合を考劣ればよく， この場合の伝播時間を $t_{B \cdot n \tau=0}$ とすれば, $(2.23)$ 式からただちにつぎの関係が導かれる。 
図一2.5 流域斜面の伝播状態を表わす特性曲線 $\left(\boldsymbol{t}_{d}<\boldsymbol{t}_{B \cdot r}\right)$

Fig. 2.5 Characteristic curves showing propagation states of rainfall disturbance on side slope surface in the case of $t_{d}<t_{B \cdot r}$

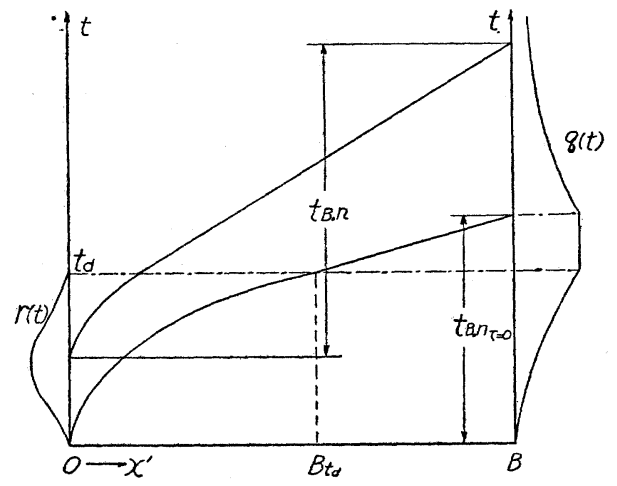

$t_{B \cdot n \tau=0}=p^{\prime} B K^{\prime 1 / p^{\prime}} /\left(R_{t d}\right)^{1 / p^{\prime-1}}+\left(1-p^{\prime}\right) t_{d}$,

ただし， $R_{t d}=\int_{0}^{t_{d}} r(t) d t$.

つぎに流路に扔いては, 上流端から下流端までの伝播時間 $t_{L}=t-\tau$ と, 横からの流入量 $q(t)$, 流路上流端からの流入 量 $Q(0, \tau)$ 招よび流路特性との間に，(2.8) 式によつてつぎ の関係が成立する。

$$
p L K=\int_{\tau}^{t} d s\left[\left\{\int_{\tau}^{s} q(z) d z / K\right\}^{1 / p}+Q(0, \tau)\right]^{1-p} .
$$

この式は, 流路内に扔ける雨水の伝播状態が, 横からの流 入量 $q(t)$ と流路上流端からの流入量 $Q(0, \tau)$ の二つの要素 飞支配されることを示すが，特別の場合を除いて $Q(0, \tau)=$ 0 と考劣てよい。また短期間の急激な流出現象, 寸なわち洪 水を対象とする場合には，常に $q(t)$ があると考光てよく， 斜面の遅滞効果によつて $q(t)$ は $r(t)$ 飞較べてかなり屙平 化されるから, $q(t)$ の形状効果を無視することができよう。 したがつて結局，(2.18) 式の誘導と全く同様にして,つぎの

関係が求められる。

$$
t_{L}=K L^{p} / q_{m}{ }^{1-p}, \quad \text { ただし } q_{m}=\int_{t_{L}} q(t) d t / \int_{t_{L}} d t
$$

な抒，自然流域と扔ける流出過程を本理論で数值的追跡寸るには，流域をいくつかの小流域分割する必要 があり ${ }^{7)}$, この場合には各分割流域の上流端からの流入量 $Q(0, \tau)$ はいちじるしく大きくなり, 横からの流入効果 を無視することができる。したがつて各分割流域内の流路に招ける伝播時間 $t_{L}$ は, $(2.25)$ 式で $q(t)$ を無視し てえられる関係

$$
t_{L}=p L K Q(0, \tau)^{p-1}
$$

そよればよいが，計算方法については本論文の目的外であるから，この程度にとどめて括こう。

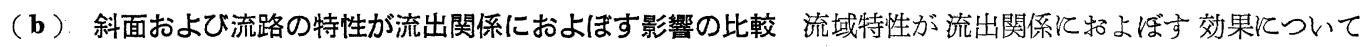
は，すで特性曲線法による計算法を用いて詳しく論議し，山間地流域では斜面特性が流路特性よりもいちじる しく大きい影響を与兄ることを確かめている8)。ここではこの問題を解析的な形で改めて考察しょう。

一般に流出特性を決定するのは伝播時間であつて，伝播時間は遅滞の位相差を表わすだけでなく，流れの量を る規定する。このことは，観測点に和ける流量 $Q$ が一般に

$$
Q=\int_{t_{L}} \frac{\int_{t_{B}} r(t) d t}{t_{B}} \cdot d t \cdot \frac{B L}{t_{L}}
$$

の形で表わされ， $B, L$ 抢よび $r(t)$ も伝播時間 $t_{B}, t_{L}$ を支配し, 結局 $Q$ は $t_{B}, t_{L}$ によつてきまつてくるか らである。

このようと流量曲線は降雨曲線の一種の写像とも考えられ，その写像関係を決定するのが伝播時間であり，こ の意味で伝播時間は流出関係に招よぼす流域特性の効果を総合的に表現するすのとい方よう。伝播時間 $t_{B}, t_{L}$ が ともに 0 の場合には，降雨曲線はそのままの形で流量曲線に移行するから，流域特性の効果は全くないことにな る。伝播時間の増加は, 流量への写像をひずめる効果を大きくするから, これは結局流域特性の効果の增大を意 味する。したがつて斜面と流路とが流出関係に招よぼす効果を比較するには，それぞれの伝播時間の大小を検討 すればよいであろう。

ここでは，降雨中に雨水擾乱の伝播が斜面全体を招招う場合を取り扱ろが，洪水を対象とする流出問題では， すべてとうした場合と考えてよい。(2.18) 招よび (2.26) の両式から, 斜面招よび流路と招ける伝播時間 $t_{B}, t_{L}$ はそれぞれ

$$
\begin{array}{lll}
t_{B}=K^{\prime} B^{p^{\prime}} / r_{m^{1}}{ }^{1-p^{\prime}}, & \text { ただし } & r_{m}=\int_{t_{B}} r(t) d t / \int_{t_{B}} d t, \\
t_{L}=K L^{p} / q_{m^{1}}{ }^{1-p}, & \text { ただし } & q_{m}=\int_{t_{L}} q(t) d t / \int_{t_{L}} d t,
\end{array}
$$

で表わされる。ところが雨水はまず斜面上を流れて流路に流入し，さら飞流路を通つて観測点に達するから， $t_{B}$ と $t_{L}$ との比較するには，図-2.2 そ示すように降雨の同一時間部分に対応するものについて考えねばならな 
い。この場合には，(2.11) 式からつぎの関係が成立する。

$$
q_{m}=r_{m} B \cdots
$$

したがつて, $(2.28) \sim(2.30)$ の 3 式から,

$$
S_{t} \equiv \frac{t_{L}}{t_{B}}=\frac{K L^{p}}{K^{\prime} B^{\prime 1-\left(p-p^{\prime}\right)}} r_{m}^{p-p^{\prime}}
$$

となる。ここに， $p^{\prime}$ およびゃはそれぞれ斜面拉よび流路と括ける断面積〜流量関係を示す值であるが，流れがと

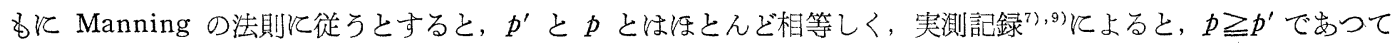
$p$ - $p^{\prime}$ は大体 0.1 程度である。斜面上の流れを二次元流と考光, 流路形状を矩形とすれば, $p^{\prime}=p=0.6$ となる。

したがつて $p^{\prime}=p$ の近似をとつて, (2.31) 式を

$$
S_{t}=K L^{p} /\left(K^{\prime} B\right)
$$

としても，十分の精度をもつであろう。この式によれば， $S_{t}$ は流域特性のみ支配され，降雨特性関係しない ことがわかるのであつて, 流域特性と流出特性の関係を定量的と表わす重要な無次元表示と考光ることができ, Horton の形状係数 $F=B / L$ 飞較べて，はるか、水理的意義の明らかなるのである。

自然流域では一般に $K^{\prime}$ は $K$ の数倍程度の值であるから ${ }^{7), 9), ~} K^{\prime}=5 K$ と招き, $B=1000 \mathrm{~m}, L=20000 \mathrm{~m}$ と 招いて, $p=0.6$ とすると, (2.32) 式から $S_{t} \fallingdotseq 1 / 10$ となる。したがつて, 自然流域の $S_{t}$ の值は, 数分の 1 から 数十分の 1 程度であることがわかる。 $S_{t}=1$ の場合は, 降雨から流量への時間的遅れ飞招上ぼす斜面と流路との効 果が等しいことを意味し， $S_{t}$ が小さくなるほど，斜面の効果が流路のそれに比して大きいことを示して招り，上 の結果は斜面が流路に較べてきわめて大きい効果を拉よぼすととを実証するるのである。

また面積一定の流域からの出水を較べると， $L / B$ を増すほぞ，斜面上流端から観測点までの到達時間が減少す ることを証明できるが，同時に降雨の平均強度が低下寸るという経験的事実を考光ると， $L / B$ の值のみをるつて 出水の危険度を判定することは早計であるう。

（c）最大流量の発生条件 ここでは, 降雨のどの時間部分が最大流量に関与するかといろ問題を取り扱つて, 最大流量を発生する伝播の出発時刻と到達時刻との関係を求めることにする。この場合, 斜面から流路への流入 量曲線についての条件を与えれば，前項で考察したように流路内伝播の流出関係に抽よぼす効果がきわめて小さ いことから，観測点飞括ける流出機構も近似的にはその条件飞支配されるるのと考光てよい。

さて, 斜面から流路への流入量 $q(t)$ は, (2.11) 式から

$$
\begin{aligned}
& q(t)=\left\{\int_{\tau}^{t} r(t) d t / K^{\prime}\right\}^{1 / p^{\prime}}, \\
& q(t)=r_{m} B \ldots \ldots \ldots \ldots \ldots \ldots \ldots \ldots \ldots \ldots
\end{aligned}
$$

と表わされ，(2.34) 式に（2.18）式を入れて $r_{m}$ を消去すると，

$$
q(t)=\left\{B K^{\prime} /(t-\tau)\right\}^{1 /\left(1-p^{\prime}\right)} \text {. }
$$

となる。さらに, (2.33) 招よび (2.35) 式を $t$ で微分して 0 と括けば, 最大流入量の発生条件としてつぎの 2 式 をろる。

$$
r(t)-\frac{d}{d t} \int_{0}^{\tau} r(t) d t=0
$$

および $\quad \frac{d}{d t}(t-\tau)=0$

(2.37) 式は最大流入量を発生する降雨部分の伝播時間が極小であることを意味し，またこのとき $t$ との微 分が等しいことを示している。したがつて (2.36) 式から, 最大流入量を発生する伝播の出発時刻 $\tau_{p}$ と到達時 図一2.6 $\left(\boldsymbol{t}_{p}-\tau_{p}\right)$ と降雨および流量曲線との 刻 $t_{p}$ とに招ける降雨強度が相等しいことになり,

関係

Fig. 2.6 Relation between $\left(t_{p}-\tau_{p}\right)$ and curves of rainfall and discharge

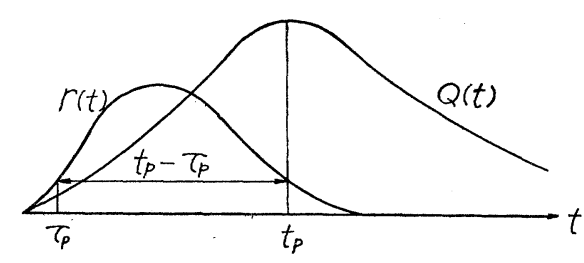

$$
r\left(\tau_{p}\right)=r\left(t_{p}\right)
$$

と表わされる。この式は, 降雨のピークをはさんで強度の等し い時間内の降雨が最大流入量飞関与することを示するので, こ ろした関係が钼測点流量飞搇いても成立すると考光，かつ損失 現象を考慮しなければ，降雨と流量の実測記録を用い 図-2.6 のようにして，ただちと最大流量の伝播時間 $\left(t_{p}-\tau_{p}\right)$ を求め ることができる。

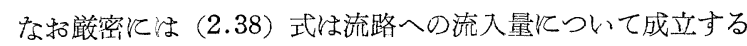
ものでめるから，図一2.6 のような操作で求められた最大流量の伝播時間に，ぞの程度の誤差があるかを考えて 
扔く必要がある。この場合，伝播の到達時刻 $t_{p}$ は確が最大流量の括こる時刻であるから問題はなく，誤差の 原因出発時刻 $\tau_{p}$ にあるはずである。実際上は流路内の伝播時間 $t_{L}$ につて, 最大流量伝播の出発時刻 $\tau_{p s}$ に 扔ける降雨強度 $r\left(\tau_{p s}\right)$ 怔一般飞 $r\left(\tau_{p}\right)$ より少し大きくなるから, 図一2.6のようにして求めた $\left(t_{p}-\tau_{p}\right)$ の值 は実際の伝播時間 $\left(t_{p}-\tau_{p s}\right)$ より少し過大になつてくる。そこで両者の関係を，

$$
\left(t_{p}-\tau_{p}\right)=\left(t_{p}-\tau_{p s}\right)+l t_{L}
$$

と抢けば, $l$ は $\tau_{p}$ と $\tau_{p s}$ の間の降雨の分布形状によつて変化し, 一般に 0 より大きい值であつて, $\tau_{p}$ 直後の $t_{L}$ 区間拉よび $t_{p}$ 直前の $t_{L}$ 区間の降雨の時間分布が等しいときはほぼ $1 / 2$ の值をとる*。さらに

$$
t_{p}-\tau_{p s}=t_{B}+m t_{L}
$$

と表わされ, $m$ は $t_{L}$ 時間内の流入量 $q(t)$ の形状によつて変化するが， $q(t)$ が $r(t)$ 飞較べてかなり扁平化さ れているから， $m$ の值は核ぼ $1 / 2$ と考光てょい*。

以上の 2 式加占, 䜋差 $l t_{L}$ と $\left(t_{p}-\tau_{p}\right)$ との比 $\sigma$ は,

$$
\sigma \equiv l t_{L} /\left(t_{p}-\tau_{p}\right)=l S_{t} /\left\{1+(l+m) S_{t}\right\}
$$

となるから，実伝播時間 $\left(t_{p}-\tau_{p s}\right)$ は次式で与兄られる。

$$
t_{p}-\tau_{p s}=\left(t_{p}-\tau_{p}\right)(1-\sigma)=\left(t_{p}-\tau_{p}\right)\left[1-l S_{t} /\left\{1+(l+m) S_{t}\right\}\right] \cdots
$$

したがつて, 流路内の伝播時間 $t_{L}$ の効果が大きいと考兄られるときは, $l$ 招よび $m$ を $1 / 2$ と招いて (2.42)

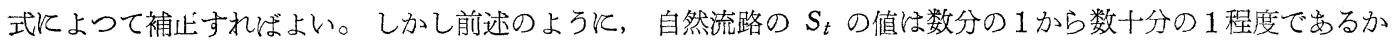
ら，わが国の河川のような小流域の場合には一般にのがきわめて小さく，(2.38）式をその委観測点最大流量 の発生条件と考光てよいであるう。

（d） 斜面と流路の要素の総合化 斜面と流路とでは, 雨水の挙動がいらじるしく違つているから，これらを区 別して取り扱うことが必要である。しかし，斜面と流路のそれぞれの要素には物理的意義に招いて対応するるのが 多く, ことそ地表面流だけを対象とする場合には，流下距離，勾配括よび粗度係数といつた全く同じ物理的意義 をもつた要素からなつていると考光てよい。したがつて，単位図法を対象とした本論文の目的からいつて，結果 としては斜面と流路を切り髉して処理したときと同一の現象形態を与えるような総合量として，単一の流域要素 を考光ることができる。こうした意味での総合要素を添字 0 をつけて表わすこととし，

$L_{0}:$ 流下距離で, $B$ と $L$ の総合量

$\sin \theta_{0}:$ 勾配で, $\sin \theta^{\prime}$ と $\sin \theta$ の総合量

$n_{0}:$ 粗度係数で, $n^{\prime}$ と $n$ の総合量

$K_{0}:$ 流域の要素で, $K^{\prime}$ と $K$ の総合量

とする。以下の考察では，流域特性としてこれらの総合要素を用いることとするが，これらと斜面招よび流路の 特性との相関は非常に複雑であつて，単飞加光たり平均值をとつたりすることは許されない。B. D. Richard など の従来の研究では， ほとえどが斜面と流路を区別せずと等価取り扰い，降雨はその降下点から観測点河つて 直線的に流れるとしているが，こうした立場に立てば，総合要素の決定はかなり容易になる。しかし実際上はこ の仮定は妥当でなく，ここでことさらに総合要素と名付けた意味はこの点てあるのであつて，その意義は流出機

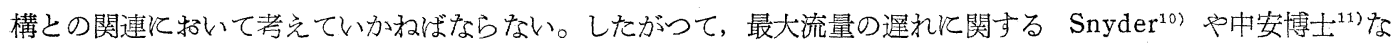
ぞの経験公式に招いて，観測点から流路最遠点までの距離と流域重心点までの距離との幾何平均あるいは流域最 大幅といたる距離との幾何平均として，流下距離の効果が導入されていることは，注目すべきものといえよう。

総合要素と斜面扔よび流路の要素との相関は, 今後の重要な課題であるが, 前述の流路, 斜面の伝播時間比 $S_{t}$ は一つの示陖を与兄るものであつて，その考察結果からみて，総合要素は主として斜面要素儿支配されると考兄 ることができよう。

\section{3. 単位図法の力学的意義亡流出現象の線型性}

\section{（1）単位図法の力学的意義}

* この場合，斜面と流路に扔けるそれぞれの最大流入量扔よび最大流量の発生条件と，流入量扔よび伝播の式 (2. 11), (2.18) から, $l=(1 / 2)\left(r_{m t_{L}} / r_{m t_{L}}{ }^{\prime}\right) \geqq 1 / 2$ なることを証明できる。ここK, $r_{m t_{L}}$ は $t_{L}$ 区間の平均降雨強

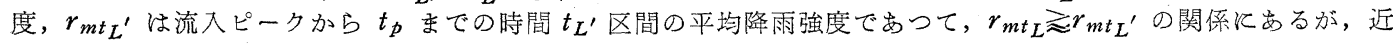
似的飞両者を等しい々考克てょい。

** $m=t_{L^{\prime}} \mid t_{L}$ であるから, * の場合と同様に $\tau_{p}$ 直後の $t_{L}$ 区間と $t_{p}$ 直前の $t_{L}$ 区間の降雨分布が等しいと仮 定すれば， $m=l$ となることを証明できる。しかし，こうした仮定の拘束は，l飞対しては強いが $m$ 飞対しては

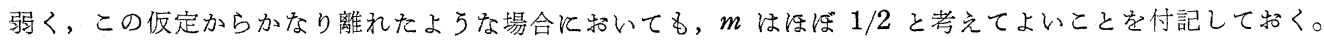


ここでは単位図法が成立するための力学的条件を述べるが, 流域の諸要素は前章で説明した総合要素で表わし， また運動方程式の指数 $p$ 抢よび $p^{\prime}$ は医とんど等しいとして，以下ではともに $p$ を用いることにする。

総合要素は前述のようと主として斜面要素に支配されるが，最も問題になる雨水の流下径路については，流域

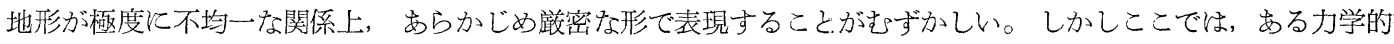
法則にもとづいて生れたと考兄られる単位図法と，これとは異なる法則に従つていると考光られる実際の流出現

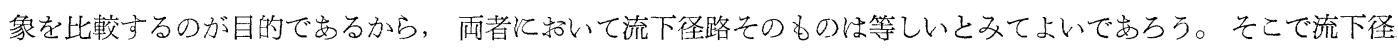
路に沿つてとるといろ概念的な意味で, 総合流下座標 $x_{0}$ を考光ることにする。しかしこの座標系は, 流域内の ある地点から観測点向つて雨水が直線的に流下するといつた 従来の意味に扔けるすのでなく, 出発点によつて 種々の径路をもつことが予想されるが，等高線に直角方向に連続したものとするのも，一つの考方方であろう。 この場合，斜面と流路とを形式的には区別していないが，適当に総合要素を用いることによつて，両者を区別し たと同様な結果を観測点に挌ける流出現象に与览にことができ，渠たこの座標系下では 全体にわたつて降雨を流 入量とすればよい。

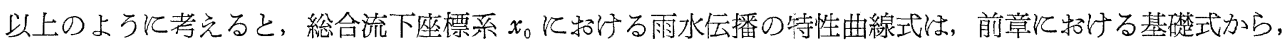

$$
\frac{d x_{0}}{d t}=\frac{1}{p K_{0}^{1 / p}}\left\{\int_{\tau}^{t} r(t) d t\right\}^{1 / p-1}
$$

または $\quad x_{0}=\frac{1}{p K_{0}{ }^{1 / p}} \int_{\tau}^{t} d s\left[\int_{\tau}^{s} r(z) d z\right]^{1 / p-1}$

と表わされ，その上で流量の関係式

$$
Q=\left[\int_{\tau}^{t} r(t) d t / K_{0}\right]^{1 / p}
$$

が成立することになる。この流量 $Q$ はある一つの流下座標 $x_{0}$ に沿つたもので, 実際の観測点流量はこの $Q$ を すべての流下方向について積分したものでなければならない。

また，総合流下座標系では流れを二次元流としてょいから，運動方程式は

$$
h=K_{0} Q^{p} \text {....... }
$$

となり, 指数 $p$ は Manning の抵抗法則によつた場合 0.6 となり, Palmer ${ }^{6)}$ の実験結果もとの妥当性を実証し ていることは前述のと括りである。

さて単位図法は，流域の遅滞特性が流出量曲線によつて総合的に表現されるという基本的立場にたつて，つぎ の三つの仮説てもとづいている。

1. 降雨の場所的分布は一様とし，ある一流域と括いては，時間平均強度括よび継続時間を等しくする降雨飞 よる流出は，その流域の前期条件にかかわらず，ある特定の型をるつている。

2. 継続時間が等しく, 時間平均強度が変化する降雨群からの流出は, その時間配分変化せず, 各時間の流 量が時間平均強度飞比例して増減するだけである。

3. 前の二つの仮説は，降雨が孤立したものであつても，また一連降雨のなかのでこに位置していても，常に 成立する。

以上の三つの仮説について力学的に検討するが，まず第一の仮説の最も重要な点は，流域では流出型が降雨条 件のみによつて定まるということである。ところが一流域でもその特性が常に一定とは限らず，季節による樹草

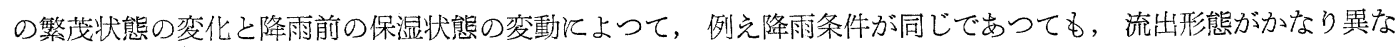
つてくるであろう。しかしこうした流域条件の問題は, 力学的対象として考克るよりる，いわゆる水文学的考察 によつて処理すべきものとして，ここでは一応この仮説を諗めて挌くことにする。

第二, 第三の仮説は，以下に述べるように全く等価であつて，現象の線型性に依存するものである。すなわ ち, 流量が降雨強度に比例するという第二の仮説は, 線型現象の特質である重合わせの原理にもとづくもので, 降雨と流量の関係式 (3.3) 飞执いて, $p=1$ であることを必要とする。また第三の仮説は, 雨水の伝播状態が降 雨条件に影響されないことを示するので，伝播式（3.1）または（3.2）飞执いて $p=1$ であることを意味する。 その場合には，伝播状態は明らかと流域特性 $K_{0}$ のみで定まり，伝播速度は

$$
\frac{d x}{d t}=1 / K_{0}=v \overline{\sin \theta_{0}} / n_{0}
$$

となつて，水深の効果を考慮しない Manning 型流速と同一のるのとな。

以上の考察から明らかなように, 単位図法の仮説が成立するのは, $p=1$ となつて運動方程式が線型の場合であ つて, 第二招よび第三の仮説は線型仮説といえよう。立神博士 ${ }^{12)}$ は流量曲線の塖減部のみについて, Horton の貯 
溜方程式から単位図法の成立条件を論じて招られるが，本研究に括けるような取り扱いによれば，単位図法仮説 の成立条件として運動方程式が一次であることを要するから，当然立神博士の取り扱いるる含むことになる。

ところが実際の流出現象では一般に $p$ は 1 でなから, 単位図法の基本仮説が撖密に成立しないわけである が，現在のところ最も優れた流出解析法として，単位図法が広く用いらている。例光ば理論的な流出問題の取り 扱いとして有名なZoch の理論"では，その前提としてまず, “任意時刻の流量はとの時刻の貯溜量に比例する”, あるいは “排水点での流量はとの水深に比例する”という仮定を执いているが，これは明らか、 Horton 型貯溜方 程式を認めるか, あるいは運動方程式が線型であることを意味し, 単位図法の仮説の意義と全く同様である。した がつてZoch の理論は, 単位図法に較べて, 高次の力学的意義をるつているとは考尘られない。さらに単位図法 は単位図とよばれる単位流出量曲線によつて，個々の流域がるつている特有の性状を表現しょうという優れた思 想を含んで招り，極度に不均一な流域に拾ける雨水の流出現象を把握する一つの方法として，示唆富むるのと いえよろ。したがつて単位図法は, 力学的意義はかわらないとしても, 生簡明され捻いてはもちろん, 実際の 流出現象を正しく把握できる点に括いて，Zoch の理論よりはるか優れたものと考兄られる。

\section{（2）流出現象の線型性}

前節で述べたように，単位図法は明らかに線型仮説にもとづいているから，その適用性が流出現象の線型性に 依存していることはいうまでもない。わが国のように非線型性の強い流出現象注しては, 従来から単位図法の 適合性が低下寸るといわれているが，流出現象の線型性の意義を明確にしておくことが，単位図法の精度あるふ は適用限界といつた実際的な工学上の問題を究明する基礎とるなるので，以下に少し考察を加少う。

流出現象飞関与する因子を大別すると，降雨特性と流域特性とになるから， これらの諸特性と現象の線型性と の関連を考えていくことが必要である。一般に運動現象が急激なとき，つまり関係する物理量の時間特よび距離 飞関する微係数が大きいときには，その非線型の強度が増加するから，線型の基礎である重合わせの原理から求 められる結果，すなわちここでは単位図法の精度低下が予想される。しかしある一地点と持ける雨水流の挙動に 直接関係し, 運動方程式の線型性と関連があるのは, 降雨特性としてはとの平均強度と時間的変動であり, また 流域特性としてはその勾配と摩擦をあらわす粗度であつて, 降雨の継続時間や流域の面積㧍よび形状々のものは, 運動方程式の線型性とは関連をもつていない。このことは，降雨の継続時間は現象の継続する時間，すなわち時 間的な場を与えるものであり，また流域の面積や形状は現象の空間的な場を与えるものであつて，流出現象の線 型性とは直接な関連をるつていないからである。乙かしわれわれの対象とする山間地の流出現象では，これらの 時間的な場や空間的な場が，現象の線型性を直接支配する降雨や流域の要素とかなりな相関をるつているから， 流出現象を全体として把握しようとする場合，これらの場の大きさが重合わせの原理から導かれる単位図法の精 度に影響をるつことになる。それルしても，これはあくまで降雨执よび流域の諸特性との関連に怙いての重合わ せの近似度という問題であつて, 現象の線型, 非線型に関する要素の挙動によつては, 単位図法の精度を高めも し，低めるするものであつて，単位図法の精度に対する場の効果を一義的に考劣ることはできないはずである。

\section{4. 単位図法の精度と降雨および流域の諸特性との関係}

前章の説明から明らかなよう飞, 降雨の平均強度と時間的変動招よび流域の勾配と粗度は, 流出現象の線型性 飞直接関与するものであつて, 単位図法の精度を左右する。すなわち, 運動現象が急激で非線型性が強くなるの は, 降雨の平均強度と時間的変動が大きく, 粗度が小さくて勾配の大きい場合であつて, こうした場合忙単位図 法の精度は当然低下することになる。しかしながら，流域の大きさ招よび形状と降雨の継続時間については，そ れだけでは単位図法の精度との関係を論ずることができない。そこでこれらの場の大小抢よび形状と基礎方程式 の線型性を直接支配する降雨执よび流域の特性との相関を考虑しながら, 单位図法の精度との関係を求めていく こととする。

\section{（1）単位図法における伝播速度と流量の表示}

単位図法の仮説によると, 雨水の伝播速度 $\omega_{u}$ は一定の流域では降雨条件にかかわらず一定としているが, (3.1) 式を考慮して,

$$
\omega_{u}=\left(1 / p K_{0}^{1 / p)} \alpha_{t}\right.
$$

と表わせば， $\alpha_{t}$ はつぎのようとなる。

$$
\alpha_{t}=\left\{\int_{\tau}^{t} r(t) d t\right\}^{1 / p-1}
$$

また単位図法の仮説で怯, 流量 $Q_{u}$ が降雨強度, 実際汇法ある時間区分すなわち单位時間内の降雨量に比例す るとしているが, (3.3) 式を考虑して， 


$$
Q_{u}=\left(\alpha_{q} / K_{0}^{1 / p}\right) \int_{\tau}^{t} r(t) d t
$$

と表わせば， $\alpha_{q}$ はつぎのようになる。

$$
\alpha_{q}=\left\{\int_{\tau}^{t} r(t) d t\right\}^{1 / p-1}
$$

以上のようにすれば，単位図法の伝播速度括よび流量関する係数 $\alpha_{t}, \alpha_{q}$ の間に，

$$
\alpha_{t}=\alpha_{q}
$$

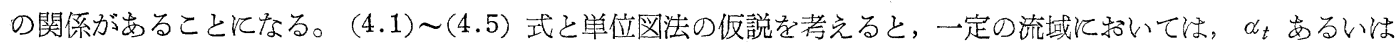
$\alpha_{q}$ が降雨条件の変動に左右されず一定でなけ机ばならない。ところが (4.2) あるいは (4.4) 式の右辺は, 降雨 の時間配分によつて変動し，また伝播汇要する時間 $(t-\tau)$ が含まれている。しかも $(t-\tau)$ 㤏雨特性だけでな

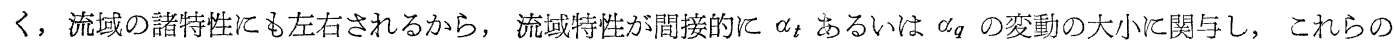
変動が単位図法の精度を支配することは明らかである。

さて，伝播の変動効果を表現する $\alpha_{t}$ と流量の変動効果を表現する $\alpha_{q}$ との間には，(4.5) 式の関係があるか ら，伝播に関する単位図法仮説と流量に関するとれとが，降雨拉よび流域のいずれの特性にも支配されないで相 関をるつことてなる。このことは，きわめて興味ある事実であつて，総合単位図法への方向に一つの重要な基礎 を与古るものであろう。なぜならば，単位図の縦距を単位時間内の雨量飞比例させることによつて，流出量曲線

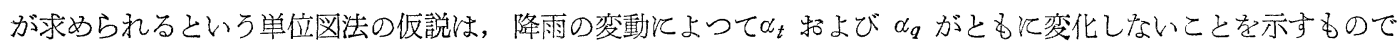
あつて， $\alpha_{t}$ あるいは $\alpha_{q}$ のいずれか一方がこの条件を満足すれば，(4.5) 式から明らかなよう他の一方もこの 条件を满足することになつて，単位図法の伝播怙よび流量についての二つの仮説が同時に 成立するととになるか らである。

乙かしながら， $\alpha_{t}$ 抢よび $\alpha_{q}$ は降雨条件泫よつて変動し，またその変動の程度は流域の特性によつて子支配さ

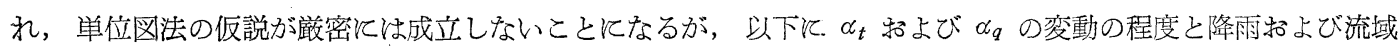
の特性との関係について，定性的と考察しょう。な拉， $\alpha_{t}=\alpha_{q}$ なる関係があるから，ここでは $\alpha_{t}$ のみを取りあ げて呿く。

\section{（2） $\boldsymbol{x}_{0} \sim t$ 面における $\alpha_{t}$ の変動}

$\alpha_{t}$ の $x_{0} \sim t$ 面上の変動を考学ると，(4.2) 式の関係によつて一般に $\tau, t$ 和よび $x_{0}$ の関数となる。い未， $\tau$ を固定し一つの特性曲線のみについて考觉れば，その特性曲線上に括ける $\alpha_{t}$ の変動は，

$$
\frac{d \alpha t}{d t}=\left(\frac{1}{p}-1\right)\left\{\int_{\tau}^{t} r(t) d t\right\}^{1 / p-2} r(t) \geqq 0
$$

と表わされ，図一 4.1 亿示すように，r(t)>0 すなわち降雨の続く間は正であり， $r(t)=0$ すなわち降雨がやんだ

\section{図一-1.1 一特性曲線上における $\alpha_{t}$ の変動}

Fig.4.1 Variation of $\alpha_{t}$ on a characteristic curve.

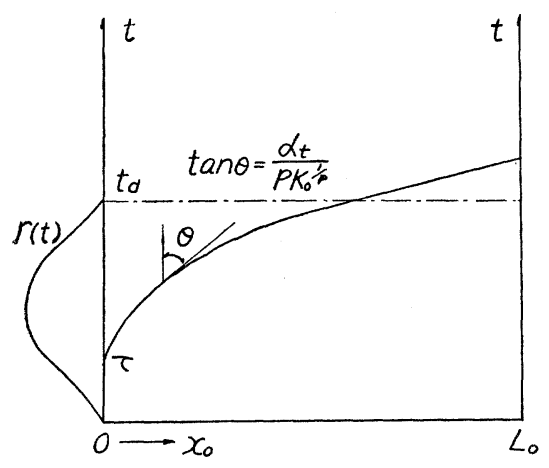

後は 0 となつて， $\alpha_{t}$ は一定となる。ところがてを固定しない場 合には， $\alpha_{t}$ の変動は $\tau$ によつても支配される。そこで $x_{0}$ 金固 定して，時間方向飞抬ける $\alpha_{t}$ の変動を考党ると，

$$
\frac{\partial \alpha_{t}}{\partial t}=\left(\frac{1}{p}-1\right)\left\{\int_{\tau}^{t} r(t) d t\right\}^{1 / p-2}\left\{r(t)-\frac{\partial}{\partial t} \int_{0}^{\tau} r(t) d t\right\}
$$

となり， $\alpha_{t}$ の時間的変動は上式右辺の第三括弧内の正負によつ て増加または減少する。

さて, 流域の大きさ $L_{0}$ と降雨の継続時間 $t_{d}$ の大小片つて, 流出機構はつぎの (a), (b) の二つの場合にわけられる。

(a) $L_{0}$ が小さいか $t_{d}$ が大きくて, $\tau=0, x_{0}=0$ から出発す る標準特性曲線 s. c. が降雨中江下流端椡達する場合には, 流 量のピークは降雨中に生じる。

(b) $L_{0}$ が大きいか $t_{d}$ が小さくて, s.c.が降雨終了後に下流 端に到達する場合には, 流量のピークは降雨終了後に生じる。

そこでまず（a）の場合とついて考觉よう。特性曲線が $x_{0}$ 軸，すなわち $\tau=0$ の点から出発するときは， $\frac{\partial}{\partial t} \int_{0}^{\tau} r(t) d t=0$ で $r(t)>0$ であるから， $\partial \alpha_{t} / \partial t>0$ となつて， $\alpha_{t}$ は s. c. までは単調に增加する。 s. c. か b $t_{d}$ までは, $\left\{r(t)-\frac{\partial}{\partial t} \int_{0}^{\tau} r(t) d t\right\}$ の正負とよつて $\partial \alpha_{t} / \partial t$ 引 0 となり， $\alpha_{t}$ の増減は降雨曲線の時間的変動飞 支配される。 $t_{d}$ 以後は $r(t)=0, \frac{\partial}{\partial t} \int_{0}^{\tau} r(t) d t>0$ であるから， $\partial \alpha_{t} / \partial t<0$ となつて $\alpha_{t}$ は単調と隇少する。以上 
図-4.2 (a) の場合の $\boldsymbol{x}_{0} \sim t$ 面内における $\boldsymbol{\alpha}_{t}$ の変動

Fig.4.2 Variation of $\alpha_{t}$ on $x_{0} \sim t$ plane in the case of (a)

図-4.3 (b) の場合の $x_{0} \sim t$ 面内における $\alpha_{t}$ の変動

Fig.4.3 Variation of $\alpha_{t}$ on $x_{0} \sim t$ plane in the case of (b)

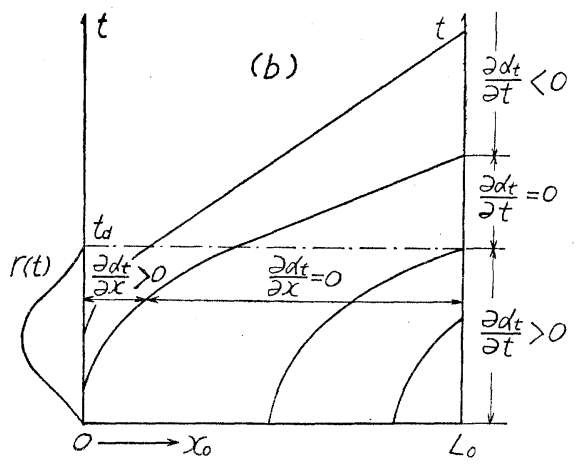

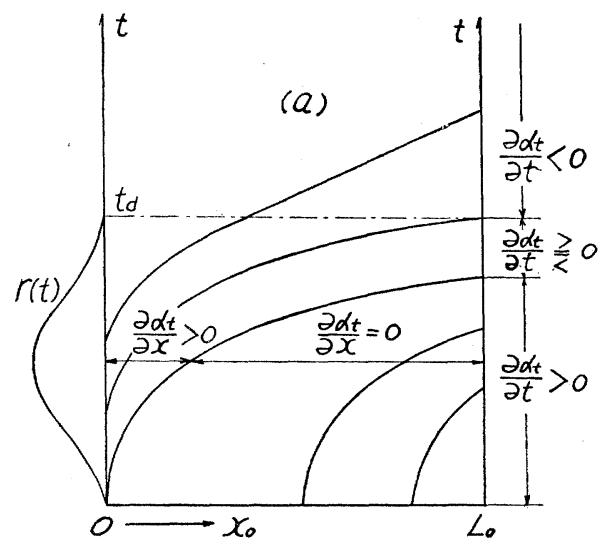

の関係を模型的に図示すれぶ，図-4.2 のと㧍りである。 つぎに (b) の場合には, $t_{d}$ までは $r(t)>0, \frac{\partial}{\partial t} \int_{0}^{\tau} r(t) d t$ $=0$ であるから,$\partial \alpha_{t} / \partial t>0$ となつて $\alpha_{t}$ は単調に増加する。 $t_{d}$ 以後 s. c. までは $r(t)=0, \frac{\partial}{\partial t} \int_{0}^{\tau} r(t) d t=0$ であるから， $\partial \alpha_{t} / \partial t=0$ となつて $\alpha_{t}$ は一定となる。 s. c. 以後は $r(t)=0$, $\frac{\partial}{\partial t} \int_{0}^{\tau} \boldsymbol{r}(t) d t>0$ であるから, $\partial \alpha_{t} / \partial t<0$ となつて $\alpha_{t}$ は単調 に減少する。以上の関係を模型的に図示すれば，図-4.3 のと 特りである。

さらに $\alpha_{t}$ の $x_{0}$ 方向の変動を考えると,

$$
\begin{aligned}
& \frac{\partial \alpha_{t}}{\partial x_{0}}=\frac{\partial \alpha_{t}}{\partial t} \frac{\partial t}{\partial x_{0}}+\frac{\partial \tau}{\partial \alpha_{t}} \frac{\partial \tau}{\partial x_{0}} \\
& =\left(\frac{1}{p}-1\right)\left\{\int_{\tau}^{t} r(t) d t\right\}^{1 / p-2} \cdot \frac{\partial}{\partial \tau} \int_{\tau}^{t} r(t) d t \cdot \frac{\partial \tau}{\partial x_{0}}
\end{aligned}
$$

となり， $\frac{\partial}{\partial \tau} \int_{\tau}^{t} r(t) d t$ 拉よび $\partial \tau / \partial x_{0}$ の正負を考えればよい。 この場合も $\alpha_{t}$ の $t$ 方向の変動を考光たときと同様に， $L_{0}$ 掠 よび $t_{d}$ の大小沉って (a), (b) 二つの流出機構にわけられ るが, これらのいずれの場合についても, つぎのように考察す ることがでさる。すなわち，図-4.2 特よび 図-4.3 亿示すよ うであつて, ともに $x_{0}=0$ から s.c. までは $\frac{\partial}{\partial \tau} \int_{\tau}^{t} r(t) d t<0$, $\partial \tau / \partial x_{0}<0$ であるから, $\partial \alpha_{t} / \partial x_{0}>0$ となつて $\alpha_{t}$ は $x_{0}$ 方向に 単調に増加する。S. c. から下流端 $L_{0}$ までは $\frac{\partial}{\partial \tau} \int_{\tau}^{t} r(t) d t=0$, $\partial \tau / \partial x_{0}=0$ であるから $\partial \alpha_{t} / \partial x_{0}=0$ となつて $\alpha_{t}$ は $x_{0}$ 方向に 一定となるはずである。

\section{(3) $\alpha_{t}$ の変動と流下距離および降雨継続時間亡の関係}

前節で述べた $L_{0}, t_{d}$ という空間的, 時間的場に拉ける $\alpha_{t}$ の変動にもとづいて, 単位図法の精度と $L_{0}$ 拉よび $t_{d}$ との関

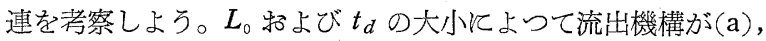
(b) の三つの場合にわけられることは, さきに述べたと㧍りで あるが，これらを結びつけて図示したのが 図一4.4 であつて， $L_{01}$ 括よび $L_{03}$ はそれぞれ (a)，(b) 飞属する流 下距離であり， $L_{02}$ はその境界である。この場合， $L_{01} \leqq L_{02} \leqq L_{03}$ であることはいうまでもない。

(a) の場合には， $L_{0}$ の増加につれて， $\partial \alpha_{t} / \partial t \gtreqless 0$ の区域すなわら降雨の時間分布に左右される区域が減少し， （a）と（b）との境界（c）飞いたつてこの区域は０となる。（b）の場合には， $\partial \alpha_{t} / d t=0$ すなおち降雨の時間分布 そ影響されない区域が， $L_{0}$ の増加につれて増していく。ところが前に述べたように，単位図法は $\alpha_{t}$ の時間的変 動の減少につれて精度を向上するから， $L_{0}$ の増加が単位図法の精度を向上させることになる。しかしこれは，降 雨の時間的場である $t_{d}$ と空間的場である $L_{0}$ とが互い独立であるためにいるることであつて，両者が何らかの 相関をもつならば，こうしたことを一義的汸いことができない。

降雨の時間的場の大きさ，すなわち $t_{d}$ は $\alpha_{t}$ との関連関する限り $L_{0}$ と逆関係にあるが， $t_{d}$ は流出現象の 発生の源である降雨量との関連に抮いてとりあげねばならない。降雨量は洪水の程度を直接左右するから，大洪 水を間題とする場合は当然といえよう。降雨の量と強度が比例して，降雨の時間的分布が相似であるような場合 は, 単位図法の精度に対する $t_{d}$ の減少の效果快， $L_{0}$ の増加の効果と等価であるが，こうした場合の $t_{d}$ の減少 は降雨強度ひいてほ洪水の強度を減退させ，あまり問題とならないであろろ。現実の問題として，洪水の程度に 直接の效果を括よぼす降雨の量を一定と考えると， $t_{d}$ の減少は平均降雨強度を増加して，むしろ現象の非線型性 を増大させることになる。ほた周知のように， $t_{d}$ の減少につれて一般に降雨強度を増加し，その時間的変動を急 激ならしめるから, こうした場合の単位時間のとり方の複雑さと相まつて, 工学的立場からすれば $t_{d}$ の減少はむ しろ単位図法の精度を低下させるでめろう。 


\section{図一4.4（a）および（b）の場合を結びつけて示した $x_{0} \sim t$ 面内における $\alpha_{t}$ の時間的変動}

Fig.4.4 Hourly variation of $\alpha_{t}$ on $x_{0} \sim t$ plane in the combined case of (a) and (b)

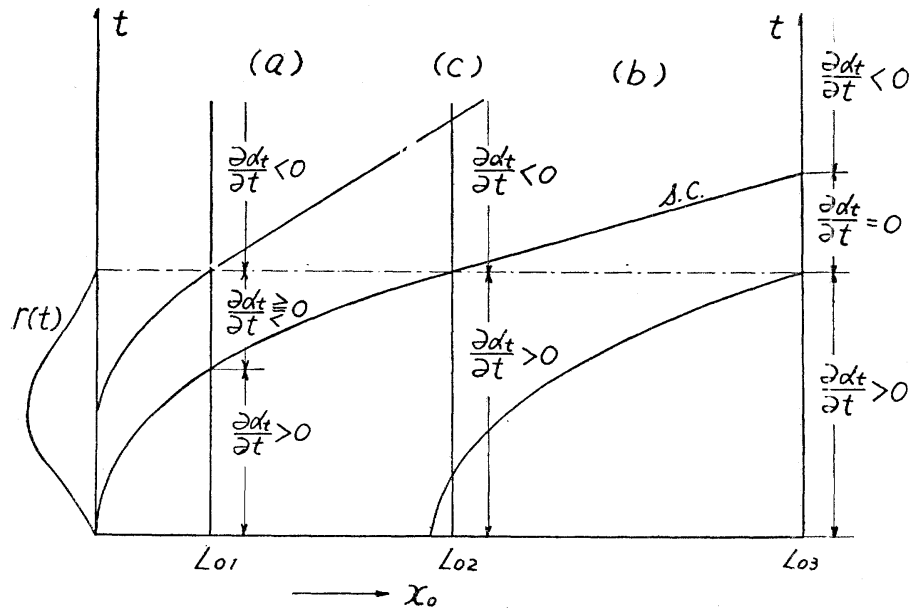

（4）降雨の場所的分布と単位図 法の精度

一般に大規模な現象を考える場合 には，現象の発生源の場とその伝播 の場とを分離する必要があるが，流 出現象では前者は流域内の降雨区域 であり，後者は降雨区域から観測点 までの面積である。

流域面積の大きさをする代表的な 距離を $L_{0}$ で表わすと, 図一4.5 か ら明らかなよう飞， $L_{0}$ は次式で与 兄られる。

$$
L_{0}=L_{n}+L_{r}+L_{p},
$$

ここに， $L_{n}$ は流出現象飞関与しな 距離 (面積)， $L_{r}$ 以降雨のある距 離 (面積)， $L_{p}$ 注現象が伝播してい く距離(面積)である。したがつて， 流出現象江直接関係するのは $L_{r}$ と
図-4.5 降雨の場所的分布と 流下径路亡の関係

Fig.4.5 Schematic diagram showing the relation between areal rainfall distribution and runoff route.

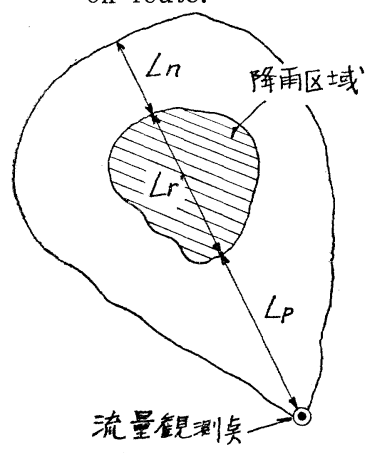

$L_{p}$ であつて，ここに降雨の場所的分布を考慮することが必要となる。とこで $L_{p}$ と $L_{r}$ の大小と $\alpha_{t}$ との関連染考皇ると， $L_{p}$ が0でない場合には，そこを 流下する雨水の前面で一種の衝撃波が発生するから， $L_{p}$ の増下沉下下流端 飞括汓る $\partial \alpha_{t} / \partial t>0$ の部分が減少し， $\partial \alpha_{t} / \partial t=0$ の部分が増加する。したがつて 図一4.6 飞示すように, $L_{p}$ の増加は $\alpha_{t}$ の時間的変動を減退させて, 単位図法 の精度を向上させる。な括， $L_{p}$ ボ増加すると浸透との他汇よる雨量椇失を增し， 有效降雨の平均強度を低下寸るから，さらにこのことが助長されるであるう。し たがつて, 一流域に招ける降雨面積, 勂際には洪水に最も效果の大きい降雨区域 から流量観測点までの距離を増すほど，単位図法の適合性がよくなつてくる。す なわち，单位図法の精度は $L_{p} / L_{r}$ の増加とともに向上し，一般には $L_{p}$ が流域 面積の増加につれて大きくなるから，降雨の時間的分布の均一化とる相秃つて，

$L_{0}$ の増加が単位図法の精度を向上させることになるはずである。

さらに, 降雨の平均強度は流域面積を増す汪ど一般に減少するが，このことは 面積の増加が流出現象をまするす線型と近づけることを意味するから，この点か らも笚位図法の精度を向上させるものといえよう。

図一 4.6 $L_{p} \neq 0$ の場合における $\alpha_{t}$ の時間的変動

Fig.4.6 Hourly variation of $\alpha_{t}$ in the case of $L_{p} \neq 0$

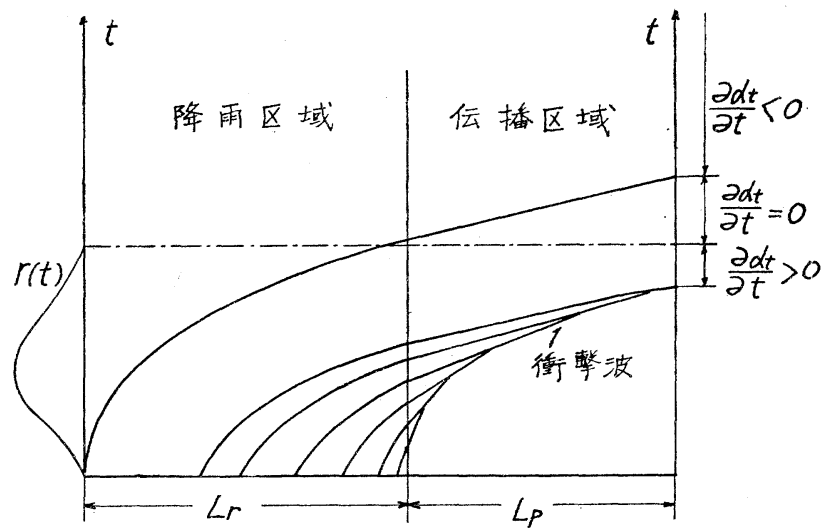

しかしながら，単位図はその基礎仮説に よつて，流域内の一様な降雨からの流出量 曲線であるとされているから，流域面積が 過大になつて，降雨の場所的分布が注な だしく不均一になると， $\alpha_{t}$ の時間的変動 の低下や平均降雨強度の減少上りも, 基礎 仮説からの偏倚の影響が大きくなつて，単 位図法の精度はむしろ低下するであろう。 米国で単位図法の適用が $2000 \mathrm{mile}^{2}$ 以上 の流域には不適当といわ机ているのは，降 雨分布の場所的不均一を考息てためと思わ れる。

（5）単位図法の精度についての総括

前節までの考察結果からわかるように,

問題となるのは運動方程式の非線型性にもとづく $\alpha_{t}$ の変動と降雨招よび流域の特性との相関関係であつて， $\alpha_{t}=$ 
$\left\{\int_{\tau}^{t} r(t) d t\right\}^{1 / p-1}$ の平均値のまわりの変動が大きくなれば，単位図法の精度が低下するわけである。いま，降雨 $r(t)$ を時間 $t$ だけの偶然関数とみなすと， $\alpha_{t}$ の集団は物理的条件で規制された時間区分 $(t-\tau)$ 内に特ける $r(t)$ の和集合，つまり集合 $r(t)$ の部分集合の集合と考光ることができ，こうした集団の平均值が時間区分 $(t-\tau)$ の 増加につれてある一定值に近づくことは, 確率論的に証明されている。したがつて, 時間区分 $(t-\tau)$ を増加させ るような物理的条件は, 単位図法の精度を向上させることになる。この場合, 降雨平均強度や流域の粗度掠よび 勾配といつた現象の線型性に関与する要素と流下距離执よび降雨継続時間とは, 単位図法の精度あるいは適合性 との相関に括いて, 統計集団 $r(t)$ の時間区分 $(t-\tau)$ の大小との関連については形式的同じ意味をるつが，そ の物理的意義が全く異なつていることを再び強調して招きたい。このことは, 前節までの $\alpha_{t}$ 変動と単位図法の 精度との関係についての考察が最大流量付近にかぎるのであつて, 流出過程全体にわたるときは, $\boldsymbol{t}_{t}$ は 0 からあ る值まで変化し，流出過程全体についての $\alpha_{t}$ 変動の強弱と場の大小との間には，一義的な相関を見出すととが できないからである。ただ最大流量付近だけにかぎるときは，場の大きさの増加とともに $\alpha_{t}$ の分散の度合が小 さくなるとしても, 場の大小と線型性関与する要素との間に相関があり，ことに降雨は時間だけの偶然関数で なく，場の大小とはかなりの相関があるから，こうした面からも場の大小と単位図法の精度との関係が考兄られ るととになるのである。

要するに, 線型性関与する要素々単位図法の精度との関係は, 力学的意義からわかるように一義的普遍的で あるが, 場の大きさを示す要素については, 工学的重要性抽よ゙要素間の内的相関によつて, 単位図法の精度と の関係が考觉られるのであつて，その関係が一義的でないことを注意すべきである。

以上を考慮して，線型性に関与する要素だけをとりあげると，つぎのような場合に単位図法の精度が向上する。

1. 降雨の平均強度が小さく, 降雨曲線の変動がわずかで滑らか飞変化する場合。

2.流域の粗度が大きい場合，したがつて流域に招ける樹草の繁茂状態はとくに重要な因子となるであるう。

3. 流域の平均勾配が小さい場合。

つぎに，場の大小拉よび形状については，一般につぎのような場合に単位図法の適合性が増加するとい方よう。

4. 流域面積が大きい場合，乙かし過大になつて降雨の場所的分布があまり不均一になると，かえつて単位図 法の適合性が低下するから，こうした場合には流域を適宜分割して適用すべきである。

5. 流域形状が比較的集約的である場合，これは降雨の場所的分布を均一化するとともに，斜面の流下距離を 増加して，流域の総合的流下距離 $L_{0}$ を増すという効果をも考虑しているからである。

6. 降雨の継続時間が比較的長い場合，しかしこれは降雨の総量呿よび時間的分布と継続時間との相関を考慮 しているためであつて，も乙降雨が時間だけの偶然関数であるとすれば，結論は逆となつてくる。

\section{5. 流出機構の分類亡単位図法による最大流量の適合条件}

雨水流出の機構は，降雨㧍よび流域の特性飞支配され，乙たがつてまた流出機構の差異に応じて，単位図法の 取り扱いを異にすべぎある。るた前章までに明らがしたように，単位降雨の単位強度と単位時間をいが適 当に選しだとしても，その結果としてえられる単位流出量曲線すなわち単位図は， $\alpha_{t}$ が時間の関数である以上， 流出の時間的場所的の全過程を通じて，単位図法の仮説を満足することができない。実際問題としては，一流域 では場所を固定した特定位置の流出が対象となるから， $\alpha_{t}$ の時間的分布だけをとりあげればよいが，それとして

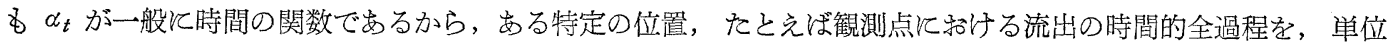

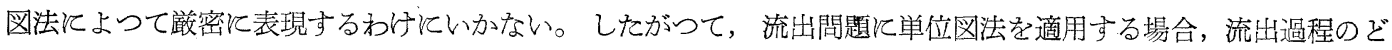
の部分飞着目するかとよつて，単位降雨あるいは単位図の要素が違つてくるはずである。単位降雨を瞬間降雨と 考觉てよいという立場をよく見受けるが，これは単位図法の線型仮説が笮密汇成立することを前提としたるので あつて，流出の実態を無視したものとい元う。

本章では，単位図法を適用するときの取り扱いの差異によつて流出機構を分類し，それぞれの場合について单 位図法の適合条件を検討する。この場合流出のピークに着目することにするが，これは工学的立場からすれば当 然であろう。

\section{（1） $\alpha_{t}$ の平均化}

単位図法によつて対象降雨からの流出のピークが正しく推定できるように，単位降雨を求めようとする場合， 最大流量を発生する特性曲線 m. c. 上の $\alpha_{t}$, すなわち $\alpha_{t p}$ が問題となるが，取り扱い上 m. c. の上江和活る

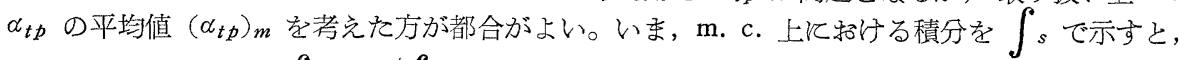

$$
\left(\alpha_{t p}\right)_{m}=\int \alpha_{s} \alpha_{t p} d t / \int s d t \text {. }
$$


であるが，m. c. が時間について単調増加するから，(5.1) 式はつぎの積分と等価になる。

$$
\left(\alpha_{t p}\right)_{m}=\int_{\tau_{p}}^{t_{p}} \alpha_{t p} d t / \int_{\tau_{p}}^{t_{p}} d t
$$

ここに，神招よび $t_{p}$ は m. c. の出発時刻と到達時刻である。ところが (4.2) および (3.2) 式から，

$$
\int_{\tau_{p}}^{t_{p}} \alpha_{t p} d t=p L_{0} K_{0}^{1 / p}
$$

の関係が党られから，(5.2) 式は

$$
\left(\alpha_{t p}\right)_{m}=p L_{0} K_{0}{ }^{1 / p} /\left(t_{p}-\tau_{p}\right)
$$

となる。この関係は， $L_{0}$ を伝播時間 $\left(t_{p}-\tau_{p}\right)$ で割つた m. c. の平均接線（伝播の平均速度）飞 $p K_{0}^{1 / p}$ をかけ たものが $\left(\alpha_{t p}\right)_{m}$ であると考光ても, 簡単汇求めることができる。

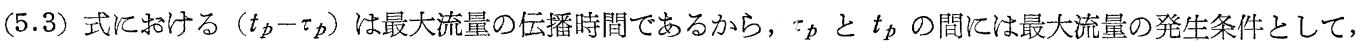
$r\left(\tau_{p}\right)=r\left(t_{p}\right)$

の関係が成立しなければならないて，また降雨条件によつてはいくつものピークを生じるから，その場合には

$$
t_{p}-\tau_{p} \leqq t_{p i}-\tau_{p i}
$$

を満足すべきこともいうおでもない。ここに， $\tau_{p i}$ と $t_{p i}$ はとれぞれピークを発生する特性曲線の出発時刻と到 達時刻である。

さて, $\left(t_{p}-\tau_{p}\right)$ の表現は， $t_{p}$ が降雨時間中にあるか，またはとれ以後にあるかとよつて異なつてくる。まず $t_{p}$ $<t_{d}$ （前章 (2)の (a) の場合) ならぼ, (2.18) 式から

$$
t_{p}-\tau_{p}=K_{0} L_{0}{ }^{p} / r_{m p}{ }^{1-p} \text {, ただし } r_{m p}=\int_{\tau_{p}}^{t_{p}} r(t) d t / \int_{\tau_{p}}^{t_{p}} d t
$$

となり，をて $t_{p}>t_{d}$ (前章 ( 2 )の (b) の場合)ならば，(2.24）侙から

$$
\begin{aligned}
& t_{p}-\tau_{p}=\left\{p L_{0} K_{0}^{1 / p}+(1-p) r_{m}^{1 / p-1} t_{d}^{1 / p}\right\} /\left(r_{m} t_{d}\right)^{1 / p-1}, \\
& \text { ただし, } r_{m}=\int_{0}^{t_{d}} r(t) d t / \int_{0}^{t_{d}} d t
\end{aligned}
$$

となる。したがつて (5.3)〜 (5.5) 式からそれぞれの場合について $\alpha_{t p}$ の平均值はつぎのようと表現され，こ れが後汇述べる単位図法の決定因子となる。

$$
\begin{aligned}
& t_{p}<t_{d} ;\left(\alpha_{t p}\right)_{m \cdot s}=\left(p L_{0} K_{0}{ }^{1 / p}\right)^{1-p}\left(p r_{m p^{1 / p-1}}\right)^{p}, \ldots \ldots \ldots \ldots \ldots \ldots \ldots \ldots \ldots \ldots \ldots \ldots \ldots \ldots \ldots \ldots \ldots \\
& t_{p}>t_{d} ;\left(\alpha_{t p}\right)_{m \cdot l}=\left\{p L_{0} K_{0}{ }^{1 / p}\left(r_{m} t_{d}\right)^{1 / p-1}\right\} /\left\{p L_{0} K_{0}{ }^{1 / p}+(1-p) r_{m}{ }^{1 / p-1} t_{d^{1 / p}}\right\} .
\end{aligned}
$$

\section{(2) 流出機構の差異による分類}

単位時間を $t_{u}$, 対象降雨の継続時間を $t_{d}$, 到達時間を $t_{c}$ とすると, 流出機構の差異によつてつぎの三つの場 合祆故らる。

(a) $t_{u}<t_{c}, t_{d}>t_{c}$ の場合: 流域の勾配が大きく, 粗度怙よび流下距離が小さい場合であつて，単位降雨の継 続時間すなわら午位時間中には，上流端からの伝播がとの下流端に到達しないが，対象降雨の継続時間が到達時 間より長い場合である。これはわが国では，単位図法を適用するとき教党られるほとんですべての場合であつ て，以下で流流域の場合とよぶことにする。

(b) $t_{u}<t_{c}, t_{d}<t_{c}$ の場合: 単位時間, 対象降雨の継続時間がとも飞到達時間より短い場合で, 流下距離が大 きい場合を指すことになる。米国でね一般と最大流量が降雨終了後に生じるようであつて ${ }^{13)}$ ，この場合に相当す るが，以下では大流域の場合とよぶこと飞する。

(c) $t_{u}>t_{c}, t_{d} \gtrless t_{c}$ の場合: 単位時間を到達時間よりも大きくとつた場合であつて, 単位時間を適当汇選んで 单位図法の愦差をなるべく軽減しようという立場からは，好委しいことではない。したがつて，単位図法でとり あげられるのは，(a) 招よび (b) の場合だけであろう。

\section{（3）単位図法による流出解析の適合条件}

単位降雨の $\left(\alpha_{t p}\right)_{m}$ を $\left(\alpha_{t p}\right)_{m \cdot u}$ とし, 対象降雨のとれを $\left(\alpha_{t p}\right)_{m \cdot n}$ とした場合, 単位図法を用いて最大流量を 適確に求めるために必要な関係を，上記の三つの場合についてそれぞれ導いて抗こう。

(a) $t_{u}<t_{c}, t_{d}>t_{c}$ の場合：対象降雨による最大流量を $Q_{n \cdot p}$ とすれば，つぎのように表わされる。

$$
Q_{n \cdot p}=\left\{\left(\alpha_{q p}\right)_{m \cdot n} / K_{0}^{1 / p}\right\} \int_{\tau_{p}}^{t_{p}} r(t) d t
$$

つぎに，対象降雨の最大流量を生じる伝播の平均速度が単位降雨の平均伝播速度より大きいか等しいという条 件, すなわち $\left(\alpha_{t p}\right)_{m \cdot u} \leqq\left(\alpha_{t p}\right)_{m \cdot n}$ を与光, 単位流出量曲線のピークが $t_{u}$ から伝播の到達する時刻まで続くとい ろことと，単位図法の二つの線型仮説とを考虑すれば，単位図法による最大流量 $Q_{u} \cdot p$ は， 


$$
Q_{u \cdot p}=\frac{\left(\alpha_{q p}\right)_{m \cdot u}}{K_{0}^{1 / p}}\left\{m_{1} \int_{\tau_{p}}^{t_{u_{l}=1}} r_{u} d t+\sum_{i=2}^{i} m_{i} \int_{0}^{t_{u}} r_{u} d t+m_{i+1} \int_{t_{p}-t_{u_{i=i}} t_{p}} r_{u} d t\right\}
$$

図一5.1 $\boldsymbol{t}_{u}<\boldsymbol{t}_{c}, t_{d}>t_{c}$ の場合の番号 $i$ のなる。ここと, $r_{u}$ は単位降雨の強度であり, $\left(\alpha_{q p}\right)_{m}$ は $\left(\alpha_{t p}\right)_{m}$ 説明図

Fig.5.1 Schematic diagram showing the meaning of number $i$ in the case of $t_{u}<t_{c}, t_{d}>t_{c}$

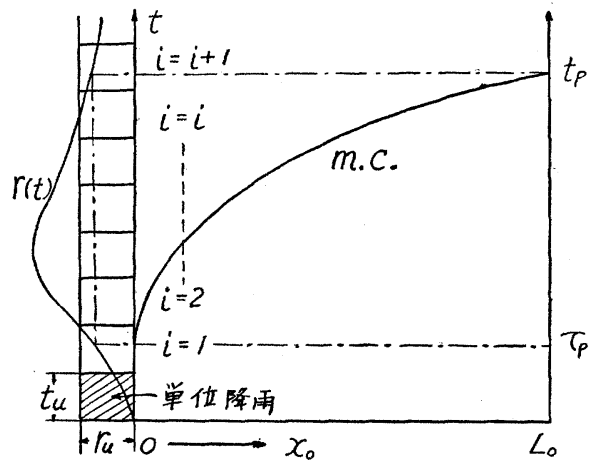
に対灾する流量の係数であつて, 両者の間には (4.5) 式の関係 がある。な特，番号 $i$ の意味は 図一5.1 のと招りであつて， $\tau_{p}$ を含を $t_{u}$ 区間を $i=1$ とし， $t_{p}$ を含む $t_{u}$ 区間を $i+1$ と している。また， $i=1$ 以前の単位降雨の流量への 影響は, 小 さいものとして無視している。

ところが単位図法の仮説から，

$$
m_{i}=\left[\int_{0}^{t_{u}} r(t) d t\right]_{i} / \int_{0}^{t_{u}} r_{u} d t
$$

であるから，(5.9) 式を書き改めると，

$$
\begin{aligned}
& Q_{u \cdot p}=\frac{\left(\alpha_{q p}\right)_{m \cdot u}}{K_{0}{ }^{1 / p}}\left\{\frac{\left[\int_{0}^{t_{u}} r(t) d t\right]_{i=1}}{\int_{0}^{t_{u}} r_{u} d t} \int_{\tau_{p}}^{t_{u_{i=1}}} r_{u} d t\right. \\
& \left.+\sum_{i=2}^{i}\left[\int_{0}^{t_{u}} r(t) d t\right]_{i}+\frac{\left[\int_{0}^{t_{u}} r(t) d t\right]_{i=i+1}}{\int_{0}^{t_{u}} r_{u} d t} \int_{t_{p-} t_{u_{i=i}}}^{t_{p}} r_{u} d t\right\} \cdots
\end{aligned}
$$

となり，(5.8) 式はつぎのように変形される。

$$
Q_{n \cdot p}=\frac{\left(\alpha_{q p}\right)_{m \cdot n}}{K_{0}^{1} / p}\left\{\int_{\tau_{p}}^{t_{u_{i=1}}} r(t) d t+\sum_{i=2}^{i}\left[\int_{0}^{t_{u}} r(t) d t\right]_{i}+\int_{t_{p}-t_{u_{i}=i}}^{t_{p}} r(t) d t\right\}
$$

いま, $t_{u}$ を適当に小さく選べば，

$$
\left.\begin{array}{l}
\int_{\tau_{p}}^{t_{i}}{ }_{i=1} r(t) d t \fallingdotseq\left\{\left[\int_{0}^{t_{u}} r(t) d t\right]_{i=1} / \int_{0}^{t_{u}} r_{u} d t\right\} \int_{\tau_{p}}^{t_{u i=1}} r_{u} d t, \\
\int_{t_{p}-t_{u_{i}=i}}^{t_{p}} r(t) d t \fallingdotseq\left\{\left[\int_{0}^{t_{u}} r(t) d t\right]_{i=i+1} / \int_{0}^{t_{u}} r_{u} d t\right\} \int_{t_{p}-t_{u_{u}}}^{t_{i=i}} r_{u} d t
\end{array}\right\}
$$

と近似できて, $Q_{n \cdot p}$ と $Q_{u \cdot p}$ の $\}$ 内の量が等しくなる。したがつて, $\left(\alpha_{q p}\right)_{m \cdot n}=\left(\alpha_{q p}\right)_{m \cdot u}$ のときには, $Q_{n \cdot p}$ $\doteqdot Q_{u \cdot p}$ となる。ところが $\alpha_{q}$ と $\alpha_{t}$ の間忙 (4.5) 式の関係があるから, 結局

$$
\left(\alpha_{t p}\right)_{m \cdot n}=\left(\alpha_{t p}\right)_{m \cdot u}
$$

なる条件を満足すれば，対象降雨の最大流量は量的にも時間的にも単位図法による計算結果と一致することにな る。

(b) $t_{u}<t_{c}, t_{d}<t_{c}$ の場合：この場合には $\tau_{p}=0$ であるから，

$$
\begin{aligned}
Q_{n \cdot p} & =\left\{\left(\alpha_{q p}\right)_{m \cdot n} / K_{0}^{1 / p}\right\} \int_{0}^{t_{d}} r(t) d t \\
& =\left\{\left(\alpha_{q p}\right)_{m \cdot n} / K_{0}^{1 / p}\right\}\left\{\Sigma_{i=1}^{i}\left[\int_{0}^{t_{u}} r(t) d t\right]_{i}\right\}
\end{aligned}
$$

となる。つぎに， $\left(\alpha_{t p}\right)_{m \cdot u \leqq}\left(\alpha_{t p}\right)_{m \cdot n}$ なる条件を与え，(a) の場合と同様な考慮をすると，

$$
Q_{u \cdot p}=\left\{\left(\alpha_{q p}\right)_{m \cdot u} / K_{0}^{1 / p}\right\}\left\{\Sigma_{i=1}^{i} m_{i} \int_{0}^{t_{u}} r_{u} d t\right\}
$$

と表わされ，単位図法の仮説汪もとづく関係

$$
m_{i}=\left[\int_{0}^{t_{u}} r(t) d t\right]_{i} / \int_{0}^{t_{u}} r_{u} d t
$$

を代入すると，つぎのようとなる。

$$
Q_{u \cdot p}=\left\{\left(\alpha_{q_{p}}\right)_{m \cdot u} \mid K_{0}^{1 / p}\right\}\left\{\Sigma_{i=1}^{i}\left[\int_{0}^{t_{u l}} r(t) d t\right]_{i}\right\},
$$

ここそ, 番号 $i$ の意味は, 図-5.2 亿示すように, 最初の $t_{u}$ 区間を $i=1$ とし, 以下順次 $2,3, \cdots \cdots, i$ とす る。

(5.13) 招よび $(5.15)$ の両式から， $\left(\alpha_{q p}\right)_{m \cdot n}=\left(\alpha_{q p}\right)_{m \cdot u}$ ，なおち

$$
\left(\alpha_{t p}\right)_{m \cdot n}=\left(\alpha_{t p}\right)_{m \cdot u}
$$

のときに， $Q_{n \cdot p}=Q_{u} \cdot p$ となることがわかる。

(c) $t_{u}>t_{c}, t_{d} \gtrless t_{c}$ の場合：この場合には 
図-5.2 $t_{u}<t_{c}, t_{d}<t_{c}$ の場合の番号 $i$ の 説明図

Fig.5.2 Schematic diagram showing the meaning of number $i$ in the case of $t_{u}<t_{c}, t_{d}<t_{c}$

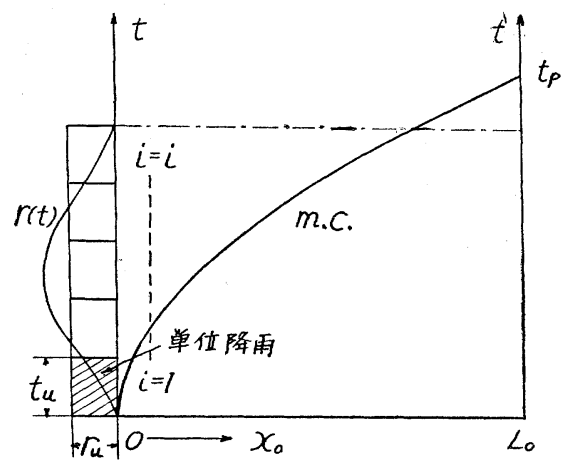

$$
\begin{aligned}
& Q_{n \cdot p}=\left\{\left(\alpha_{q p}\right)_{m \cdot n} K_{0}^{1 / p}\right\} \int_{\tau_{p}}^{t_{p}} r(t) d t, \\
& Q_{u \cdot p}=\left\{\left(\alpha_{q p}\right)_{m \cdot u} / K_{0}^{1 / p}\right\} m \int_{\tau_{p}}^{t_{p}} r_{u} d t
\end{aligned}
$$

となる。ここに，

$$
m=\int_{0}^{t} r_{u}(t) d t / \int_{0}^{t} r_{u} d t
$$

であるが，こうした場合に和ける近似関係

$$
\int_{\tau_{p}}^{t_{p}} r(t) d t \fallingdotseq\left\{\int_{0}^{t_{u}} r(t) d t / \int_{0}^{t_{u}} r_{u} d t\right\} \int_{\tau_{p}}^{t_{p}} r_{u} d t
$$

が成立するのは， $\int_{\tau_{p}}^{t_{p}} r(t) d t=\int_{\tau_{p}}^{t_{p}} r_{u} d t$ のさぎけであるから，降 雨のかなり広い変動を許すという単位図法の基本的概念が全く失わ れてしまうことになる。

したがつて以下の洘察では，（a）小流域の場合，(b) 大流域の場 合にかぎることとし，単位図法による最大流量の適合条件 $\left(\alpha_{t p}\right)_{m \cdot u}$ $=\left(\alpha_{t p}\right)_{m \cdot n}$ を用いて, 解析を進めること市る。

\section{6. 単位降雨の要素}

ここでは, 前章で求めた適合条件 $\left(\alpha_{t p}\right)_{m \cdot u}=\left(\alpha_{t p}\right)_{m \cdot n}$ を用いて, 流出量曲線のピークを単位図法で適確淮定 するために，单位降雨と降雨特性技よび流域特性との間にいかなる条件が必要であるかを明らかにしよう。

(1) 小流域の場合 $\left(\boldsymbol{t}_{u}<\boldsymbol{t}_{c}, \boldsymbol{t}_{d}>\boldsymbol{t}_{c}\right)$

単位降雨括よび対象降雨の流出機構を考慮し,

$$
\left.\begin{array}{l}
B_{c}=p L_{0} K_{0}{ }^{1 / p}, \delta=(1 / p)-1, \quad \varepsilon=1-p, \\
r_{m p}=\int_{\tau_{p}}^{t_{p}} r(t) d t / \int_{\tau_{p}}^{t_{p}} d t
\end{array}\right\}
$$

とすれば，(5.7) 拉よび (5.6) の両式からつざのようになる。

$$
\begin{aligned}
& \left(\alpha_{t p}\right)_{m \cdot u}=B_{c}\left(r_{u} t_{u}\right)^{\delta} /\left\{B_{c}+\varepsilon r_{u}^{\delta} t_{u}^{\delta+1}\right\}, \\
& \left(\alpha_{t p}\right)_{m \cdot n}=p^{p}\left(B_{c} r_{m p}\right)^{\varepsilon} . \cdots \ldots \ldots \ldots \ldots \ldots \ldots \ldots \ldots \ldots \ldots \ldots \ldots
\end{aligned}
$$

したがつて，前章（3）飞述べた条件から上の両式を等しいと掠けば，

$$
r_{u} \delta\left\{t_{u}{ }^{\delta} / p^{p}\left(B_{c} r_{m p}\right) \varepsilon-\varepsilon t_{u}{ }^{\delta+1} / B_{c}\right\}=1
$$

となる。ところが $r_{u} \delta>0$ であるから， $t_{u}$ 汇関する一つの条件不等式として，

$$
t_{u}<B_{c}^{\varepsilon-1} /\left(\varepsilon p^{p} r_{m p}^{\varepsilon}\right)
$$

がえられるが，従来経験的に選んでいる単位時間 $t_{u}$ は，(6.4) 侙の関係を十分に満足している。(6.3) 式を変 形すると，

$$
r_{u}=\left\{\left(p^{p} B_{c} r_{m p}\right)^{1 / \delta} /\left(B_{c}^{p}-\varepsilon p^{p} r_{m p}{ }^{\varepsilon} t_{u}\right)^{1 / \delta}\right\} / t_{u}
$$

となるが，一般に $B_{c}^{p} \gg \varepsilon p^{p} r_{m p}{ }^{\varepsilon} t_{u}$ であるから，近似式として次式がえられる。

$$
r_{u}=\left(p^{1 / \delta} B_{c} r_{m p}\right)^{p} / t_{u}
$$

Manning の抵抗法則を用いて， $p=0.6 ， \varepsilon=0.4 ， \delta=2 / 3$ を入れると，

$$
r_{u}=0.6^{0.9}\left(B_{c} r_{m p}\right)^{0.6} / t_{u}
$$

となり, 単位降雨の強度 $r_{u}$ が流域指標 $B_{c}$, 平均降雨強度 $r_{m p}$ の 0.6 乗飞比例し, 単位時間 $t_{u}$ 飞逆比例すべ きことがわかる。さらに $B_{c}=p L_{0} K_{0}{ }^{1} / p$ を上式と入れると，

$$
r_{u}=0.6^{1.5}\left(n_{0} L_{0} r_{m p} / \sqrt{\sin \theta_{0}}\right)^{0.6} / t_{u}
$$

となつて, 単位降雨の総量 $r_{u} t_{u}$ が一流域について $r_{m p}$ の 0.6 平借比例すべきことがわかる。いま,一例として， $t_{u}=2 \mathrm{hr}, r_{m p}=10 \mathrm{~mm} / \mathrm{hr}=10^{-2} \mathrm{~m} / \mathrm{hr}, L_{0}=1000 \mathrm{~m}$ *

$n_{0}=1 \mathrm{~m}^{-1 / 3} \cdot \mathrm{s}$

$=1 / 3600 \mathrm{~m}^{-1 / 3} \mathrm{hr}^{* *}, \sin \theta_{0}=1 / 400$

として, (6.8) 式から計算すると $r_{u}=0.05 \mathrm{~m} / \mathrm{hr}=50 \mathrm{~mm} / \mathrm{hr}$ となる。この $r_{u}$ の值は雨水流の水理学的考察から

* $L_{0}$ は主として斜面の流下距離に支配されるから，この值皇とれほど大きくない。

** $n_{0}$ は主として斜面の粗度係数 $n^{\prime}$ 飞支配され， $n^{\prime}$ の值は由良川流域で $1 \sim 1.5 \mathrm{~m}^{-1 / 3} \cdot \mathrm{s}$, 大戸川流域で 0.3

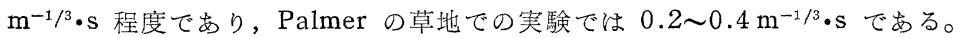


求めたもので，実測の流出量曲線から単位図法の線型仮設によつて求められているものとは，その意義を異にし ている。流れが非線型であることを考息ると，本論のような取り投いで求めた単位降雨強度がきわめて大きくなる のは，当然といつてよい。従来の単位降雨という概念は，単位図の与兄る流出総量と単位降雨の総量とを一致さ せること以外は，本質的な意義をもつて招らず，単位面積当り $1 \mathrm{~mm}$ また 1 inch といつた值がとられてい るのは, 単なる計算上の便宜からといつてよい。したがつて，こうした立場からの単位降雨と単位図の間には, 機構的にはなんの関連もなく, また単位降雨の要素, ことに単位強度をいかにとるかという論議は不可能である。 乙かし単位時間は, 単位図法によつて流出の全過程をなるべく合わせるという現象論的実際的立場からは, 重要 な問題となろろ。従来から単位降雨については, 単位時間が問題とされているのは, こうした理由によるるので ある。

(6.5) あるいは (6.6) 式は，水理学的論拠からえられた $r_{u}, t_{u}$ に関する基本式であるが，この両者をそれぞ れ独立に決定することはできない。ただ最大流量を合致させるような $r_{u}$ と $t_{u}$ の間に，こうした関係があるとい うことである。このうち $t_{u}$ の方は，流出の全過程をなるべく適確に表現するょうと選ぶという誤差論的ないし統 計的な取り扱いで定めらるべきであるう。従来から $t_{u}$ が最大流量の遅れと結びつけて考学られているのる, こう した意味に浪ならない。

最大流量の伝播時間 $t_{p c}$ は, (5.4) 式飞よつて

$$
t_{p c}=B_{c}^{p} /\left(p^{p} r_{m p}{ }^{\mathrm{g}}\right)
$$

となるから，(6.6) 式の関係を用いて，

$$
t_{u}=p^{1 / \delta}\left(r_{m p} / r_{u}\right) t_{p c}
$$

となる。したがつて，単位時間は最大流量の伝播時間比例するから，また最大流量の遅れの時間浅比例する ことになる。このことは, 最大流量の遅れの時間ととの伝播時間との間には密接な関係があり, 降雨曲線がピー クを中心として左右対称なときには，前者は後者の $1 / 2$ となるからである。この意味から， $t_{u}$ を最大流量の遅れ の時間と結びつけて求めている従来の立場は，一つの行き方と乙て合理的とい方よう。いま， $p=0.6$ と招いて (6.10) 式を書き改めると,

$$
t_{u}=0.4\left(r_{m p} \mid r_{u}\right) t_{p c}
$$

となる。 $\left(\alpha_{t p}\right)_{m \cdot u}=\left(\alpha_{t p}\right)_{m \cdot n}$ 括よび $t_{u}<t_{c}, t_{d}>t_{c}$ の条件から，Wまの場合常飞 $r_{u}>r_{m p}$ であるが， $r_{u} を r_{m p}$

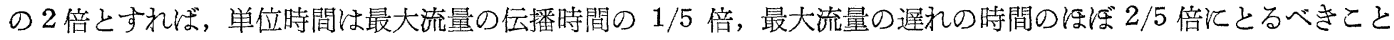
がわかる。

\section{（2）大流域の場合 $\left(\boldsymbol{t}_{u}<\boldsymbol{t}_{c}, \boldsymbol{t}_{d}<\boldsymbol{t}_{c}\right)$}

この場合， $\left(\alpha_{t p}\right)_{m \cdot u}$ は (6.1) 式で与えられるが， $\left(\alpha_{t p}\right)_{m \cdot n}$ は (5.7) 式を考慮してつぎのように表わされる。

$$
\left(\alpha_{t p}\right)_{m \cdot n}=B_{c}\left(r_{m} t_{d}\right)^{\delta} /\left\{B_{c}+\varepsilon r_{m} \delta t_{d} \delta+1\right\}
$$

ここマ, $r_{m}=\int_{0}^{t_{d}} r(t) d t / \int_{0}^{t_{d}} d t$ である。

したがつて，単位図法の仮説を流出のピーク部分で満足させる $r_{u}$ と $t_{u}$ の関係は， $\left(\alpha_{t p}\right)_{m \cdot u}=\left(\alpha_{t p}\right)_{m \cdot n}$ と抒く ことにより ,

$$
r_{u} t_{u} / r_{m} t_{d}=B_{c}{ }^{1 / \delta} /\left\{B_{c}+\varepsilon\left(r_{m} t_{d}\right) \delta\left(t_{d}-t_{u}\right)\right\}^{1 / \delta}
$$

となる。ところが一般に $B_{c} \gg \varepsilon\left(r_{m} t_{d}\right)^{\delta}\left(t_{d}-t_{u}\right)$ であるから，近似式としてつぎの関係が壳られる。

$$
r_{u} t_{u}=r_{m} t_{d}=R_{t_{d}}
$$

乙たがつて， $r_{u}$ と $t_{u}$ とは，その積が総雨量 $R_{t_{d}}$ 等しく，一方を大きくとれば，他方を小さくとることが必 要である。この場合の $r_{u}, t_{u}$ の意義も前節の小流域の場合と同様であつて， $t_{u}$ は流出の全過程をなるべく適磪 そ表現できるよう潠ぶべきである。米国では， $t_{u}$ を最大流量の遅れの時間の $1 / 2 \sim 1 / 4$ 程度とすれげよいとし ているが，これを $t_{u}$ 亿対する一つの基準としてよいであろう。

\section{（3）流域の大小と単位降雨要素との関係}

小流域と大流域の場合の単位降雨要素を，とれぞれ添字 $s$ 呿よび $l$ をつけて表わすと，(6.6) 招よび (6.14) 式によつて,

$$
\begin{array}{ll}
r_{u \cdot s}=p^{p / \delta}\left(B_{c} r_{m \cdot s}\right)^{p} / t_{u \cdot s}, & r_{m \cdot s}=\int_{\tau_{p}}^{t_{p}} r(t) d t / \int_{\tau_{p}}^{t_{p}} d t \\
r_{u \cdot l}=r_{m \cdot l} t_{d} / t_{u \cdot l}=R_{t_{d}} \mid t_{u \cdot l}, & r_{m \cdot l}=\int_{0}^{t_{d}} r(t) d t / \int_{0}^{t_{d}} d t \ldots
\end{array}
$$

となる。これらの関係式とよつて，単位降雨選定上の注意事項を，小流域と大流域とにわけて要約すると，つぎ 
のと括りである。

1. 小流域では流域指標 $B_{c}$ が重要で，流域ごとに単位降雨の要素を変えねばならないが，大流域ではころし た流域特性を考光る必要はない。

2. 降雨特性については, 小流域では降雨のピーク付近の強度が重要であるが, 大流域では降雨全体の平均強 度と継続時間あるいは降雨の総量が重要である。

3. 以上の二点からわかるようと, わが国では単位降雨の関係因于として, 流域特性とピーク付近の降雨強度に 着目することが必要であつて，一流域に括いても降雨強度の変動に灾じて単位降雨要素を変化すべきであるが， 降雨の継続時間はほとんぞ考党なくてもよい。米国などのような大流域では，降雨強度よりもむしろ降雨の総量 あるいは継続時間が重要であつて，流域特性には考慮を要しないであろう。

4. $r_{m \cdot s}$ は降雨のピーク付近の強度であつて, (6.15) 式と等価な (6.10) 式に括いて一般に $p^{1 / \delta} t_{p c}>t_{u}$ であ るから $r_{u}>r_{m \cdot s}$ であり，また $r_{m \cdot l}$ は降雨全体の平均強度であるから，小流域に括ける単位強度は大流域に敌け るものよりかなり大きくとらねばならない。しかし単位降雨の総量は, 大流域では小流域よりるきわめて大きく, 注济対象降雨の総量の程度にとら视ばならない。このととね, 単位強度として, わが国では $10 \sim 20 \mathrm{~mm} / \mathrm{hr}$, 米国 では 1 in/day がとられている理由を，定性的に説明することにならう。

5. 単位時間としては, 従来一般と最大流量の遅れの時間が基準とされている。しかし米国では, 降雨の継続 時間は最大流量の遅れの時間の $1 \sim 2$ 倍程度であるから ${ }^{13)}$ ，単位時間を後者の $1 / 2 \sim 1 / 4$ 亿とつても，単位図法 の計算は容易であるが，この基準をわが国に就いてとのまま用いると，操作が繁雑になりすぎるようである。後 に述べるように，わが国と米国では，最大流量の遅れの時間の水理学的意義が異なつているから，単位時間のと り方については，わが国独自の基準を必要とし，米国の基準をとのまま受け入れることは，害状に沿わないし， また無意味であろう。

\section{7. 単位図の要素}

単位図の重要な要素は，ピーク，上昇時間捛よび基長の三つであるが，単位図法の精度に直接影響するのはピ 一クと上昇時間であつて, 従来からこれらの要素の決定について種々の提案があるが，いずれる経験依存した ものといつてょく, 理論的裏付けが欠けているから, その普遍性には多くの疑問がある。ここでは前章までの成 果にもとづいて，最大流量とその発生時刻を適合させるような単位図のピーク特よび上昇時間について，水理学 的立場から考察を進めよう。

\section{（1）最大流量の遅れの時間}

流出機構が雨水の伝播状態に支配されることは，すでそしばしば強調したと扮りであるが，この伝播状態の一 表示と考兄られる最大流量の遅れの時間を単位図の上昇時間と結びつけている従来の立場は，こうした点注揙 をもつものといえよう。

最大流量の遅れの時間というのは, 降雨汇関して定められたある基準時刻から最大流量の 発生時刻までの時間 であつて, 降雨挌よび流域のあらゆる特性の総合効果として理解されている。この場合, 流域重心点から流量観 測点まで雨水が流下してくるのと要する時間をとることがあるが，この概念ははなはだ不明確である。おた降雨 の基準時刻として，Snyder ${ }^{10)}$ は降雨分布の重心時刻をとり，米国では一般とこの方法を用いているが，わが国で はむしろ最大降雨強度の時刻がとられている。これらは単に経験的事実に依存したものであつて, 理論的裏付け がないから，以下飞特いて水理学的立場から考察しよう。

最大流量を発生する伝播の出発時刻 $\tau_{p}$ と到達時刻 $t_{p}$ の間注, (2.38) 式によつて $r\left(\tau_{p}\right) r=\left(t_{p}\right)$ の関係が あり, 最大流量汇は $\left(t_{p}-\tau_{p}\right)$ の間の降雨が関与する。したがつて, $\left(t_{p}-\tau_{p}\right)$ は最大流量と直接関係をもつ雨水 の伝播時間と考兄られ，以下ではこれを $t_{p c}$ と表わすことにする。この $t_{p c}$ は，降雨中に最大流量を生じる $t_{p c}<$ $t_{d}$ の場合と降雨後に最大流量を生じる $t_{p c}>t_{d}$ の場合とで異なり，それぞれ $t_{p c \cdot s}$ および $t_{p c \cdot l}$ とすれば，(5.4） 呿よび (5.5) 式によつて,

$$
\begin{aligned}
& t_{p c \cdot s}=B_{c}^{p} /\left(p^{p} r_{m p}{ }^{\varepsilon}\right), \\
& t_{p c \cdot l}=B_{c} / R_{t d} \delta+\varepsilon t_{d} .
\end{aligned}
$$

となる。5.（2）の説明によつて, 前者は小流域, 後者は大流域に対応するとい方るが, ともに最大流量と直接関 係をるつ雨水の伝播時間であつて, 最大流量の遅れの時間と密接な相関をるつはずである。こうした相関を考克 るためにまず最大流量の遅れと対する降雨の基準時刻について考光て括こう。

一般に流域の大小は伝播時間の大小と対応するから，小流域にど最大流量関与する降雨部分が 減少してくる 
はずであつて，これからつぎのよう考光ることがでる。すなわち，小流域では（7.1）式からわかるように, 最 大流量付近の降雨が最大流量飞関与するから，降雨基準時刻としては，最大強度の時刻をとつた方がよい。こと 飞降雨分布が非常に非対称な場合には，降雨分布の重心を基準時刻とすることは全く不適当である。大流域では 伝播時間が大きいから，この間に多くの降雨ピークが含末れることとなり，ぬた最大ピークの時間的位置も一定 したものでない。したがつて降雨を巨視的にみて，あまり位置を変動しない降雨重心の時刻を基準とした方がよ w。

さらに大流域になつて (7.2) 式があてはまる場合には, 降雨全体が最大流量に関与してくるから, 降雨開始時 刻を基準とした方が雨水伝播の力学的機構からみて妥当である。ただしうした基準時刻をとると，(7.2）式から わかるように，最大流量の遅れの時間が降雨の総量と継続時間によつて大きく変動する。したがつて，この遅れ の時間を流域の重要な流出特性として降雨条件にあまり左右されないように 選ぶためには，降雨の重心時刻を基 準とすべきである。このことは，降雨の重心時刻を基準とした場合，降雨条件が最大流量の遅れの時間法よぼ す影響を，結果的に小さくできるからである。

要するに, 降雨基準時刻を一意的沃決定することは, 降雨条件の任意性からみて不可能であつて, 流域特性こ とそその大きさとの関連に抒いて選定しなければならない。米国では降雨の重心時刻がとられ，れが国ではむし ろ最大強度時刻が罗当とされている経験的事実は，上述の上ろな事情によるものと考学られ，それぞれの意義が 異なつているととを注意しなければならない。

つぎに最大流量の遅れの時間 $T_{g}$ と伝播時間 $t_{p c}$ との関係を考兄るが, 流出機構の相違飞よつて, $T_{g \cdot s}$ と $T_{g \cdot l}$ の二つの場合にわけることにする。添字 $s, l$ の意義は， $t_{p c}$ の場合と同様である。

\section{まず降雨中に最大流量を生じる場合には，一般に}

\section{図一7.1 降雨継続時間中に最大流量を生じる場合の雨水 擾乱の伝播状態}

Fig. 7.1 Propagation states of rainfall disturbance in the case when the peak flow discharge occurs before the end of rainfall duration

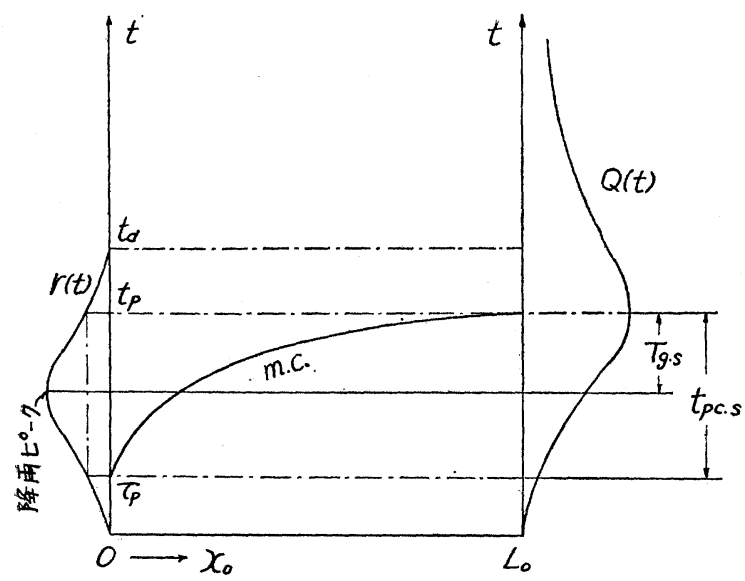

$$
T_{g \cdot s}=(1-\alpha) t_{p c \cdot s}
$$

の関係がある。この場合, 上の考察にもとづいて, 図一7.1 の上引と降雨基準時刻を最大強度の時刻上 すれば， $\alpha$ 最大流量の伝播の出発時刻 $\tau_{p}$ から最 大強度時刻までの時間之伝播時間 $t_{p c \cdot s}$ との比，す なわち $t_{p c \cdot s}$ の間の降雨分布の形状江支配されるパ ラメーターであつて, 一般に $0<\alpha<1$ の範囲にあ り，降雨のピーク付近の形状が対称なときは $1 / 2 て ゙$ ある。

降雨後に最大流量を生じる場合には，斜面上の流 下距離があらゆる点で等しいような流域では, 流出 量曲線のピークが $t_{d}$ から $t_{p c \cdot l}$ まで継続すること そなるが，自然流域の形状は不規則であつて雨水の 流下径路もきわめて多様であるから, 実際の流出現 象ではめる定まつた時刻に最大流量が発生する。乞 の時刻は， $t_{d}$ と $t_{p c \cdot l}$ の間婂くると考光られるが， これは流域特性として流出㵊す効果的な $B_{c}$ ある いは $L_{0}$ を採用している関係上，当然というべきで あろう。図一7.2 飞扮いて, 破線で示した流出量曲線は, 流域形状の不規則性を考学ず 1 本の流下径路 $x_{0}$ 亿つい ての仮想的のすのであつて，実際の流出量曲線は実線のようになるはずである。以上のことを考觉ると，

$$
T_{p \cdot l}=(1-\beta) t_{p c \cdot l}+\beta t_{d}
$$

と表わすことができ， $\beta$ は $T_{p \cdot l}$ から $t_{p c \cdot l}$ までの時間と $t_{d}$ から $t_{p c \cdot l}$ までの時間の比，すなわち流域形状の不 規則性を考虑した $t_{d} \sim t_{p c \cdot l}$ 間の $T_{p \cdot l}$ の位置を示すパラメーターであつて，一般に $0<\beta<1$ の範囲内にあり， 平均的梳 $1 / 2$ と考完てよい。

さらに, 最大流量の遅れの時間 $T_{g \cdot l}$ と $T_{p \cdot l}$ との間には,

$$
T_{g \cdot l}=T_{p \cdot l}-\beta^{\prime} t_{d}
$$

なる関係がある。この場合, 図一7.2 のようと降雨の基準時刻を降雨重心とすれば, $\beta^{\prime}$ はこの重心時刻之 $t_{d}$ と の比，すなわち降雨重心の位置を表わすパラメーターであつて，一般と $0<\beta^{\prime}<1$ の範团にあり，降雨の分布曲線 が対称な場合には $1 / 2$ である。 
図一7.2 降雨継続時間後に最大流量を生じる場合の雨水擾乱 の伝播状態

Fig. 7.2 Propagation states of rainfall disturbance in the case when the peak flow discharge occurs after the end of rainfall duration.

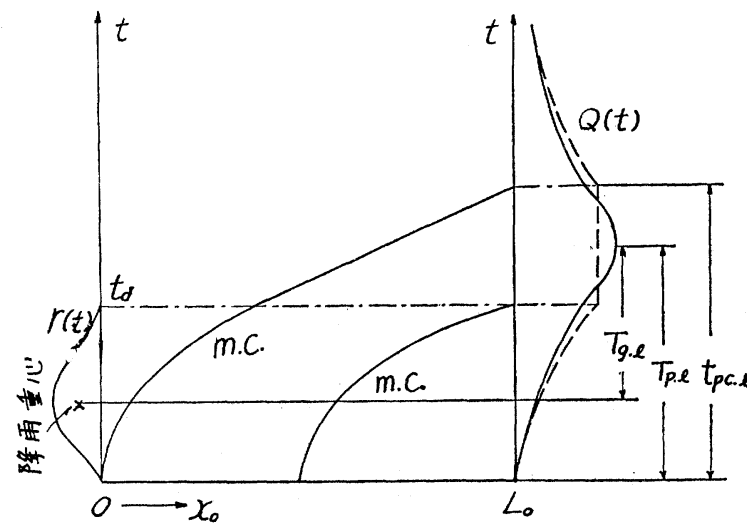

結局 $T_{g \cdot l}$ と $t_{p c \cdot l}$ との関係は, $(7.4),(7.5)$ の両侙から $T_{p \cdot l}$ を消去すること飞よつて，つぎ のようと表わされる。

$$
T_{g \cdot l}=(1-\beta) t_{p c \cdot l}+\left(\beta-\beta^{\prime}\right) t_{d} .
$$

さらに (7.1) 特よび (7.2) 式を用いて, $T_{g \cdot s}$ 物よび $T_{g \cdot l}$ を書き改めると，

$$
\begin{aligned}
T_{g \cdot s}= & (1-\alpha) B_{c}^{p} /\left(p^{p} r_{m p} \varepsilon\right), \\
T_{g \cdot l}= & (1-\beta) B_{c} / R_{t d} \delta \\
& +\left\{\varepsilon(1-\beta)+\left(\beta-\beta^{\prime}\right)\right\} t_{d}
\end{aligned}
$$

となり, パラメーター $\alpha, \beta$ 拉よび $\beta^{\prime}$ は平均的 そ1/2 と考えてよい值である。上の二つの式は， 一流域 $\left(B_{c}=\right.$ 一定) 飞猢学 $T_{g}$ の変動が，わ が国では降雨のピーク付近の強度と形状によつて 変動するという経験的事実, 米国では主として降 雨の継続時間支配され, その増加につれて $T_{g \cdot l}$ が堌大するという Taylor 招よび Schwalz の報

告 ${ }^{13)}$ を説明することになろう。

\section{（2）小流域における単位図の要素}

これは $t_{u}<t_{c}, t_{d}>t_{c}$ の場合であつて，以下の考察は一般とわが国のような小流域河川対するものといえよ ろ。

単位降雨による流出量曲線，すなわち単位図を考觉ると，その流出機構は 5.（2）の（a）の場合に相当するか ら，伝播時間 $t_{u c \cdot s}$ は (2.18) 式によつて,

$$
t_{u c \cdot s}=B_{c} /\left(r_{u} t_{u}\right)^{\delta}+\varepsilon t_{u}
$$

となる。ここで述べている単位流出量曲線は，水理学的意義をるつた単位図であるから，前節で述べたと同様の 考察によつて, 単位図の上昇時間 $t_{g \cdot s}$ は一般につぎのように表わされる。

$$
t_{g \cdot s}=\left(1-\alpha^{\prime}\right) t_{u c \cdot s}+\alpha^{\prime} t_{u},
$$

ここに, $\alpha^{\prime}$ は $t_{g \cdot s}$ から $t_{u c \cdot s}$ までの時間と $t_{u}$ から $t_{u c \cdot s}$ までの時間の比であつて, 主として流域形状に支配さ

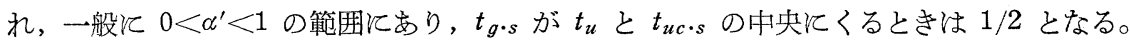

ここで目的としているのは，単位図法で最大流量を適確に表現する単位図の要素を求めることであるから，単 位降雨と最大流量の伝播時間 $t_{p c \cdot s}$ との間には, (6.5) および (6.9) の両式から $r_{m p}$ を消去して,

$$
\left(r_{u} t_{u}\right)^{\delta}=B_{c} /\left(t_{p c \cdot s}-\varepsilon t_{u}\right)
$$

の関係がある。これを(7.9) 式代代入して,

$$
t_{u c \cdot s}=t_{p c \cdot s}
$$

がえられる。この関係は, 最大流量の適合条件 $\left(\alpha_{t p}\right)_{m \cdot u}=\left(\alpha_{t p}\right)_{m \cdot n}$ からも, 直ち導くことができる。したがつ て, 単位図の上昇時間 $t_{g \cdot s}$ は, (7.10) 式から次式で表わされる。

$$
t_{g \cdot s}=\left(1-\alpha^{\prime}\right) t_{p c \cdot s}+\alpha^{\prime} t_{u} .
$$

さらに (7.3) 式の関係を用いると，

$$
t_{g \cdot s}=\left\{\left(1-\alpha^{\prime}\right) /(1-\alpha)\right\} T_{g \cdot s}+\alpha^{\prime} t_{u}
$$

となる。(7.13) 式あるいは (7.14) 式は, 最大流量の伝播時間あるいはその遅れの時間によつて表現された小流 域の場合の単位図上昇時間の決定式である。0 と 1 の間で変動するパラメーター すれば，

$$
t_{g \cdot s}=T_{g \cdot s}+0.5 t_{u}
$$

という近似式が壳られるが, 中安博士の提案式は右辺第 2 項の係数が 0.8 となつている。な特, (7.15) 式の $t_{g \cdot s}$ は最大流量を合致させるためのものであつて, 流出過程全体にわたる単位図法の平均的な精度を向上させるには, ややこれより大きい值を採用した方がよいであろう。中安博士の提案は，このことを暗示したるのと思われる。 従来一般飞単位図の遅れの時間と対象降雨のとれとを等しいとする立場から, 単位図上昇時間として概念的飞 $t_{g \cdot s}$ $=T_{g \cdot s}+0.5 t_{u}$ を用いているが，(7.15) 式とよれば十分根抛であるとい方よう。

つぎと単位図のピーク $q_{u p \cdot s}$ は, (3.3) 式によつて 


$$
q_{u p \cdot s}=\left(1 / K_{0}{ }^{1 / p}\right)\left(\int_{0}^{t_{u}} r_{u} d t\right)^{1 / p}
$$

と表わされる。いま $r_{u}$ として，単位降雨の近似式 (6.6) からえられる $r_{u}=\left(p^{1 / \delta} B_{c} r_{m p}\right) p / t_{u}$ を上式に代入する と，対象降雨による最大流量を合致させるための単位図のピークとして，

$$
q_{u p \cdot s}=p^{1 / \varepsilon} L_{0} r_{m p}
$$

がえられる。一方, 対象降雨による最大流量 $Q_{n p}$ は，

$$
Q_{n p}=L_{0} r_{m p}
$$

であるから， $q_{u p \cdot s}$ と $Q_{n p}$ の間には，

$$
q_{u p \cdot s}=p^{1 / \varepsilon} Q_{n p}
$$

の関係が成立することになり，とくに $p=0.6$ とおくと，

$$
q_{u p \cdot s}=0.6^{2.5} Q_{n p}=0.28 Q_{n p}
$$

となる。したがつて両者の関係は，水深〜流量関係の非線型指数 $p$ のみによて支配され，近似的に単位図のピ 一クは対象降雨による最大流量の $28 \%$ 程度とすればよいことがわかる。な特， $Q_{n p}$ は (7.18) と(6.9)の両式 から,

$$
Q_{n p}=L_{0}\left(B_{c} / p\right)^{1 / \delta} / t_{p c \cdot s}{ }^{1 / 8}
$$

と表わされるから, 単位面積当りの単位図のピーク $q^{\prime}{ }_{u p \cdot s}$ と降雨, 流域拉よび流出の諸特性との関係は, つぎの ようになる。

$$
q_{u p \cdot s}^{\prime}=p^{1 / \varepsilon} r_{m p}=p^{1 / \varepsilon}\left(L_{0} n_{0} / \sqrt{\sin \theta_{0}}\right)^{1 / \delta} / t_{p c \cdot s}{ }^{1 / \varepsilon}
$$

ところが $L_{0}$ の増加につれて $r_{m p}$ が減少するから， $q_{u p \cdot s}^{\prime}$ 流域面積の増加につれて減少し，また一定流域に ついて考光ると， $q_{u p \cdot s}^{\prime}$ は $t_{p c \cdot s}$ の減少につれて増大することがわかるが，これらは経験的事実と一致する。

以上のようにして求めた (7.13) あるいは (7.14) 式と（7.19）式とは，奏測流量記録から単位図を作製する ときに用いるべき基礎式であるが，これらの単位図の要素 $t_{g \cdot s} お よ ひ ゙ ~ q_{u p \cdot s}$ が降雨特性ことに降雨強度によつて いか、変化するかを考光てみよう。まず (7.13) と (6.9) の両式から，

$$
t_{g \cdot s}=\left(1-\alpha^{\prime}\right) B_{c}^{p} /\left(p^{p} r_{m p}{ }^{\varepsilon}\right)+\alpha^{\prime} t_{u}
$$

となる。したがつて一つの流域について考觉る場合， $t_{g \cdot s}$ は降雨強度の増加につれて娍少するが，上式の右辺第 1 項が第 2 項に較べてかなり大きいことから, 平均降雨強度 $r_{m p_{i}}, r_{m p j}$ 飞対応する単位図の上昇時間 $t_{g \cdot s_{i}}, t_{g \cdot s}$ の関係は，近似的次次式で与えられる。

$$
\left(t_{g \cdot s_{i}} \mid t_{g \cdot s j}\right)=\left(r_{m p j} / r_{m p_{i}}\right)^{\varepsilon}
$$

同様にして, 単位図のピーク $q_{u p \cdot s i}, q_{u p \cdot s j}$ の関係は, (7.17) 式から

$$
\left(q_{u p \cdot s_{i}} / q_{u p \cdot s j}\right)=\left(r_{m p_{i}} / r_{m p j}\right)
$$

となる。ところが $\varepsilon$ は 0.4 程度と考えてよいから, 単位図の上昇時間は降雨強度の変動によつてそれほど大きく 変化しないが，ピークは降雨強度に一次的に比例することになり，降雨強度の効果がきわめて大きいことがわか る。

由良川の実測記録から逆算した降雨強度の変動化対応する単位図要素の変化が ${ }^{14)}$, 上の両式の関係とよく一致 していることは，一つの有力な実証といえよう。一つの流域括いても，単位図を強雨強度によつて変化させる べきであるというわれわれの研究成果す ${ }^{15}$, 本節の考察によつて水理学的飞裏付けられたわけである。

\section{(3) 大流域における単位図の要素}

これは $t_{u}<t_{c}, t_{d}<t_{c}$ の場合であつて，以下の考察は一般に米国のような大流域河川に対するすのといえよう。 単位降雨による流出量曲線, すなわち単位図の伝播時間 $t_{u c \cdot l}$ 注 (2.18) 式によつて,

$$
t_{u c \cdot l}=B_{c} /\left(r_{u} t_{u}\right)^{\delta}+\varepsilon t_{u}
$$

で与えられる。一方, 単位図の上昇時間 $t_{g \cdot l}$ は, 前節と同様に流域形状の不規則性を考慮して, つぎのように表 わされる。

$$
t_{g \cdot l}=\left(1-\beta^{\prime \prime}\right) t_{u c \cdot l}+\beta^{\prime \prime} t_{u},
$$

ここマ, $\beta^{\prime \prime}$ は $t_{g \cdot l}$ から $t_{u c \cdot l}$ までの時間と $t_{u}$ から $t_{u c \cdot l}$ までの時間の比であつて, 主として流域形状に支配さ れ，一般飞 $0<\beta^{\prime \prime}<1$ の範囲内にあり， $t_{g \cdot l}$ が $t_{u}$ と $t_{u c \cdot l}$ の中央にくるときは $1 / 2$ となる。

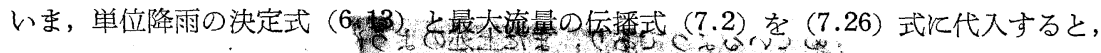

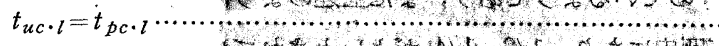

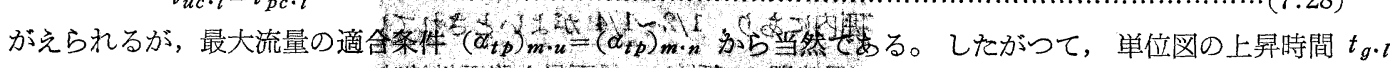

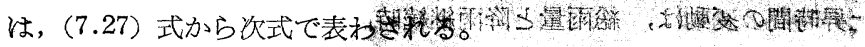




$$
t_{g \cdot l}=\left(1-\beta^{\prime \prime}\right) t_{p c \cdot l}+\beta^{\prime \prime} t_{u} .
$$

さらに (7.6) 式の関係を用いると,

$$
t_{g \cdot l}=\frac{1-\beta^{\prime \prime}}{1-\beta} T_{\boldsymbol{g} \cdot l}+\beta^{\prime \prime} t_{u}-\left(1-\beta^{\prime \prime}\right) \frac{\beta-\beta^{\prime}}{1-\beta} t_{d}
$$

となる。(7.29) 式あるいは (7.30) 式は, 最大流量の伝播時間女るいはとの遅れの時間とよつて表現された大流 域の場合の単位図上昇時間の決定式である。パラメーター $\beta, \beta^{\prime}$ 括よび $\beta^{\prime \prime}$ を平均的に 0.5 とすれば, 近似式と して,

$$
t_{g \cdot l}=T_{g \cdot l}+0.5 t_{u}
$$

がえられる。大流域ではこの式によつて単位図上昇時間が与えられているが，上述の説明からわかるように，十 分な水理学的意義をるつている。

つぎそ単位図のピーク $q_{u b \cdot l}$ は, 単位降雨の近似式 (6.14) および (3.3) 式の関係 $Q_{n p}=\left\{\int_{0}^{t_{d}} r(t) d t / K_{0}\right\}^{1 / p}$ ならびに (7.2) 式によつて,

となる。ここ泟 $C_{c}$ は,

$$
q_{u p \cdot l}=Q_{n p}=C_{c} L_{0} r_{m}=C_{c} L_{0} R_{t_{d}} / t_{d}
$$

$$
0<C_{c}=p t_{d} /\left(t_{p c \cdot l}-\varepsilon t_{d}\right) \leqq 1
$$

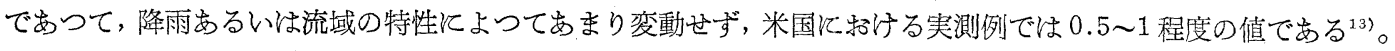
さらに (7.2) 式を用いて $R_{t_{d}}$ を $t_{p c \cdot l}$ 変換すると, 単位面積当りの単位図のピーク $q_{u p \cdot l}^{\prime}$ はつぎのように表 わされる。

$$
q^{\prime}{ }_{u p \cdot l}=C_{c}\left\{B_{c} /\left(t_{p c \cdot l}-\varepsilon t_{d}\right)\right\}^{1 / \delta} / t_{d} .
$$

ここで (7.6) 式を用いて $t_{p c \cdot l}$ を $T_{g \cdot l}$ 湾換し， $\beta$ 招よび $\beta^{\prime}$ を $1 / 2$ と特くと,

$$
q^{\prime}{ }_{u p \cdot l}=C_{c}\left\{B_{c} /\left(2 T_{g \cdot l}-\varepsilon t_{d}\right)\right\}^{1 / \delta} / t_{d}
$$

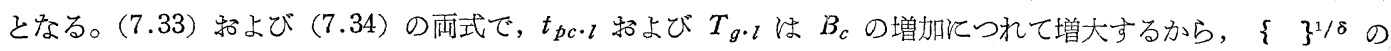
変動はわずかであるが，一般に $B_{c}$ の増加とともに少し減少する。それは (7.2) 式からわかるように，この項が 実は総雨量 $R_{t d}$ と等価であり, 流域内平均総雨量が流域面積を増す注ど減少するという経験的事実があるからで ある。いずれにしてもこの項の変動はあまり大きくないし,また $C_{c}$ ああまり変動しないからら ${ }^{13\rangle}$, 結局 $q^{\prime}{ }_{u p \cdot l}$ は継 続時間 $t_{d}$ 支配され，その増加につれて減少すると考劣てょい。

Taylor 特よび Schwarz ${ }^{13)}$ は多くの実測記録から，

$$
q_{u p \cdot l}^{\prime}=C e^{m t}{ }_{p}
$$

なる関係を与え， $C$ は流下距離の減少関数, $m$ は負符号をとる流下距離と勾配の関数としている。こうして $q^{\prime}{ }_{u p \cdot l}$

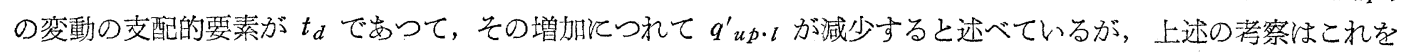
水理学的に実証したものとい方よう。な拉，(7.34) 式では $q_{u p \cdot l}^{\prime}$ が $t_{d}$ の双曲線型関数で表わされているが, 実 際に括こる $t_{d}$ の範囲では, (7.34) 式の関数が (7.35) 式の指数関数とよく似ていることを付記して㧤く。

Snyder ${ }^{10)}$ は大流域に対するものとして，

$$
q^{\prime}{ }_{u p \cdot l}=640 C_{p} / T_{g \cdot l}
$$

を提案し， $C_{p}$ を 0.56 0.69 の常数としている。上式で $640 C_{p}$ は，(7.33)，(7.34) 式の $C_{c}\{\}^{1 / \delta}$ あるいは

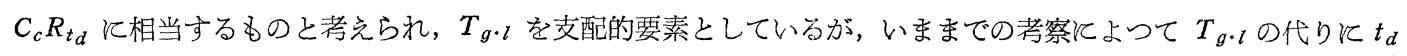

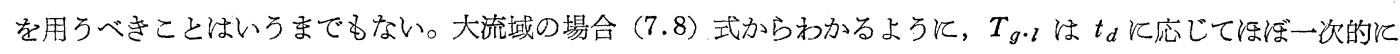
増減し，また米国では $T_{g \cdot l}$ が浪ぼ $t_{d}$ と等しい值をとるからら ${ }^{13)}$ ，実用上恃 Snyder の (7.36) 式は意義がある ろが，水理学的立場からは $T_{g \cdot l}$ の代りに $t_{d}$ を用いた方が正しいはずである。

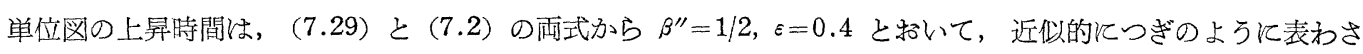
れる。

$$
t_{g \cdot l}=\left(B_{c} / 2 R_{t_{d}} \delta\right)+0.2 t_{d}+0.5 t_{u} .
$$

いま, 一つの流域を考光, $t_{u}=\eta t_{d}$ とすると, 降雨条件 $i, j$ 汶する単位上昇時間の差は,

$$
t_{g \cdot l_{i}}-t_{g \cdot l j}=\left(B_{c} / 2\right)\left(1 / R_{t d_{i}}{ }^{\delta}-1 / R_{t d j} \delta\right)+(0.2+0.5 \eta)\left(t_{d_{i}}-t_{d j}\right)
$$

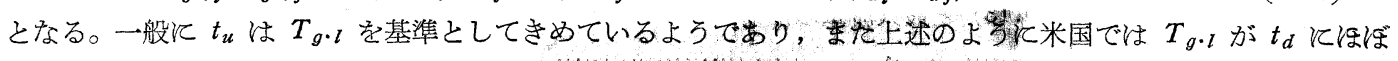

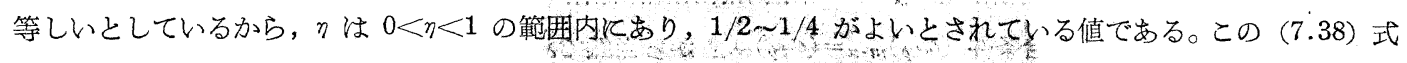
からわかるように, 降雨条件による単位図上界時䦬の変動は, 総雨量と降雨継続時間に支配され, 降雨量が少な 
く継続時間が長い場合には，上昇時間が増加してピークを後退させねね゙ならないことてなる。

つぎそ単位面積当りの単位図のピークの関係は, 降雨条件 $i, j$ K対して $C_{c}$ の変動を無覞すると ${ }^{13)},(7.33)$ 式 から

$$
\frac{q_{u p \cdot l_{i}}^{\prime}}{q_{u p \cdot l j}^{\prime}}=\left(\frac{t_{p c \cdot l j}-\varepsilon t_{d j}}{t_{p c \cdot l_{i}}-\varepsilon t_{d_{i}}}\right)^{1 / \delta} \frac{t_{d j}}{t_{d_{i}}}=\frac{R_{t d_{i}}}{R_{t d_{j} j}} \frac{t_{d j}}{t_{d_{i}}}
$$

となり，Talbot 型公式 $R_{t d}=a t_{d} /\left(b+t_{d}\right)$ を採用すると，つぎの関係がえられる。

$$
q^{\prime}{ }_{u p \cdot l_{i}} / q_{u p \cdot l j}^{\prime}=\left(b+t_{d j}\right) /\left(b+t_{d_{i}}\right) \text {. }
$$

したがつて, 単位面積あたりの単位図のピークは, 降雨継続時間の増加とともに減少するが, との変動はわず かであることがわかる。

\section{(4) 流域の大小と単位図要素との関係}

わが国のような小流域の場合と米国のような大流域の場合とでな, 流出機構を異にし, 単位図の重要な要素で ある上昇時間とピークの選定に異なつた立場を必要とすることは, 前節すで詳述したと扮りであるが，これら をとりまとめるとつぎのようである。

1. 単位図要素汇影響する降雨特性としては, 小流域では降雨ピーク付近の平均強度が支配的であるのに対し, 大流域で法雨量招よび降雨継続時間，こと飞後者が支配的である。このことは，単位図要素に関するわが国と 米国とに招ける従来の経験的事実の相違を実証している。

2. 単位図上昇時間としては, 小流域㧠よび大流域のいずれでも，最大流量の逯れの時間を基準として差支兄

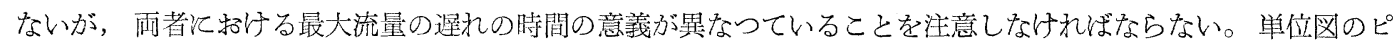
一クは小流國と大流域とでいちじるしい相違があり，前者では対象降雨の最大流量よりるかなり小さい值をとる べきであるが，後者では永等しい程度にとる必要がある。わが国で恃単位降雨の総量として, 対象降雨のそれ よりかなり小さい值をとつているの対し，米国で注 1 in といつた大きい値をとつているのは，ころした事情に よるものと思われる。

3. 降雨条件の変動飞よる単位図要素の変化は, 大流域よりも小流域の方がいちじるしく，ととに小流域に掠 ける単位図ピークの変化が顕著である。従来の単位図法がそのまま米国で広く用いられているのに反して，わが 国では種々の困難を伴つている理由は，こうしたことによつて諒解されるはずである。

4. 本章で述べた単位図要素の決定式は, 実用上飞扮いても有效であるう。こと降雨条件の変動江上る単位

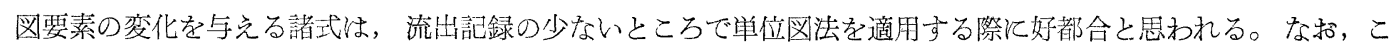
れらの関係式が総合単位図の研究に対して，重要な指針を与兄ることはいうまでるない。

\section{8. 単位図法の適用詥差}

单位図法は線型仮説㲸もとづいているから，乙れを本質的に非線型特性を有する流出問題滴用すると，当然 誤差を生じることになる。本章では単位降雨にもとづく笚位図によつて，流出解析を行つたときと生じる誤差を 検討するが，その結果は単位図法適用上の限界を明らかにし，さらに総合単位図への一つの示唆を与兄よう。

\section{（1）最大流量に関する単位図法誤差}

前 2 章で流出のピークを適合させるような 単位降雨捛よび単位図要素を与えたが，これらの関係式には降雨条 件が含まれているから，ある降雨状態汶しては满足な結果を与光ても，一般とはこうはいかないであろう。

そこで, 平均強度 $r_{m \cdot u}$ 呿よび継続時間 $t_{d \cdot u}$ の降雨*汇対して妥当な単位降雨 $\left(r_{u}, t_{u}\right)$ から求められて単位図を, 平均強度 $r_{m}$, 継続時間 $t_{d}$ なる一般の降雨飞用いた場合の最大流量呿よびその遅れの時間の詩差てついて, 小流 域と大流域とにわ惊考察しょう。

(a) 小流域の場合 $\left(\boldsymbol{t}_{u}<\boldsymbol{t}_{c}, \boldsymbol{t}_{d}>\boldsymbol{t}_{c}\right)$. 6.(1) で述べたように, 単位降雨招よび対象降雨からの $\left(\alpha_{t p}\right)_{m}$ 忙そ れぞれ (6.1) 式招よび $(6.2)$ 式で与兄られ， $\left(\alpha_{t p}\right)_{m \cdot u}=\left(\alpha_{t p}\right)_{m \cdot n}$ 在満足するような単位降雨 $\left(r_{u}, t_{u}\right)$ を用いる と, 単位図法法つて対象降雨からの流出ピークを合致させることができる。しかしこうして求められた $r_{u}, t_{u}$ は, 一定の流域に括いても, 伝播時間内のある特定の平均降雨強度 $r_{m} \cdot u$ に対してのみ妥当であつて, すべての降 雨汇対して罗当とはいえないから, ここ当然誤差が考えられてくる。

いま，伝播時間の相対誤差 $\gamma_{t}$ として，伝播速度の比をとつて，

$$
r_{t}=\frac{\left(\alpha_{t p}\right)_{m \cdot u}}{\left(\alpha_{t p}\right)_{m \cdot n}}=\frac{B_{c}^{p}\left(r_{u} t_{u}\right)^{\delta}}{p^{p} r_{m}^{\varepsilon}\left(B_{c}+\varepsilon r_{u} t_{u}^{\delta+1}\right)}
$$

* 前 2 章で求めた単位降雨怙よび単位図要素の関係式に含まれる降雨の記号 $r_{m p}, r_{m}$ 㧠よび $t_{d}$ を統一して,

$r_{m \cdot u}$ 抌よび $t_{d \cdot u}$ と表わすこととする。 
とすれば， $r_{t}=1$ のときは誤差は0で， $r_{t}$ が1よりずれるにつれて，誤差が増大することを意味する。

さて, 単位降雨の $r_{u}, t_{u}$ 性特定の平均降雨強度 $r_{m} \cdot u$ につて妥当なものであり, その関係は (6.5) 式によ ๖

$$
r_{u}=\left(p^{p_{3}} 3_{c} r_{m \cdot u}\right)^{1 / \delta} /\left\{t_{u}\left(B_{c}^{p}-\varepsilon p^{p} t_{u} r_{m \cdot u}^{\varepsilon}\right)^{1 / \delta}\right\}
$$

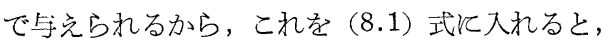

$$
r_{t}=\left(r_{m \cdot u} / r_{m}\right)^{\varepsilon}=\kappa^{\varepsilon}, \text { ただし } \kappa=r_{m \cdot u} / r_{m}
$$

となる。ここに, Manning の抵抗法則によれば $\varepsilon=0.4$ である。上侙から伝播時間の相対請差 $r_{t}$ は, 単位図の 基礎として選んだ平均降雨強度 $r_{m \cdot u}$ と対象降雨の平均強度 $r_{m}$ の上の 0.4 乗程度であることがわかる。

つぎに流量関する係数 $\alpha_{q}$ 法，伝播関する係数 $\alpha_{t}$ との間に $(4.5)$ 式の関係があるから， $\left(\alpha_{q p}\right)_{m}$ 亿関す る相対誤差 $r_{q}$ も $r_{t}$ と同様にしてつぎのようにようになる。

$$
r_{q}=\left(\alpha_{q p}\right)_{m \cdot u} /\left(\alpha_{q p}\right)_{m \cdot n}=\left(r_{m \cdot u} / r_{m}\right)^{\varepsilon}=\kappa^{\varepsilon} \text {. }
$$

そこで伝播時間 (流量) 関する誤差 $\sigma_{t(q)}$ として，

$$
\left.\begin{array}{ll}
\kappa<1 ; & \sigma_{t(q)}=1-\gamma_{t(q)}=1-\kappa^{\varepsilon}, \\
\kappa>1 ; & \sigma_{t(q)}=1-1 / r_{t(q)}=1-1 / \kappa^{\varepsilon}
\end{array}\right\}
$$

と表わすとととする。これは，たとえば $\gamma_{t(q)}=0.9$ のとき誤差 $\sigma_{t(q)}$ が $10 \%$ であることを意味する。図一8.1 は $\varepsilon=0.4$ と招いて (8.4) 式の関係を図示したものであるが, たと光ば $\sigma_{t(q)}=10 \%$ 以内にある $r_{m}$ の範囲を求 めるには，この図を用いてつぎのようとすればよい。すなわち，矢印で示したように， $\sigma_{t(q)}=10 \%$ の点から水平

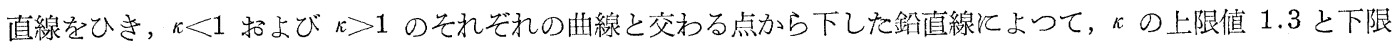
值 0.75 が求められ，これから $\sigma_{t(q)}=10 \%$ 以内となるような $r_{m}$ の範囲が求められる。

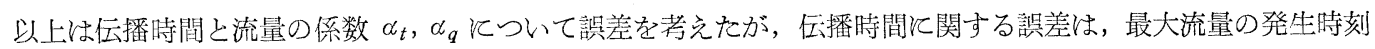

\section{図一8.1 $\sigma_{t}$ ¿ $\boldsymbol{x}$ との関係}

Fig. 8.1 Relation between $\sigma_{t}$ and $\kappa$

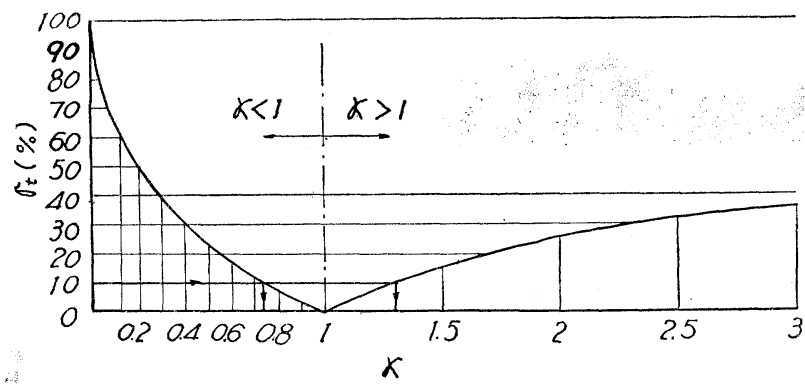
そ対しては適当な指標で怆な。その理由 は, 最大流量の発生条件として $r\left(\tau_{p}\right)=r\left(t_{p}\right)$ の関係があつて, 対象降雨の平均強度 $r_{m}$ が $r_{m \cdot u}$ 飞等しくない場合の最大流量の伝播時 間 $\left(t_{p}-\tau_{p}\right)$ の誤差を考光るとき， $\tau_{p}$ が固定 したものでないからである。

$r\left(\tau_{p}\right)$ 特よび $r\left(t_{p}\right)$ の付近飞招ける降雨分 布曲線の変化が注淁等しいと考光ると, $r\left(\tau_{p}\right)$ $=r\left(t_{p}\right)$ の条件炡つて, $\left|t_{p \cdot u}-t_{p \cdot n}\right| \fallingdotseq \mid \tau_{p \cdot u}$ $-\tau_{p \cdot n} \mid$ としてよいから, 最大流量の発生時 刻の差は伝播時間の差のほぼ $1 / 2$ となる

(図一8.2 参照)。したがつて単位図法汇よる最大流量の発生時测 $t_{p \cdot u}$ と実際のとれの $t_{p \cdot n}$ との差を中とする と,つぎのようそなる。

$$
\phi=t_{p \cdot u}-t_{p \cdot n}= \pm \frac{1}{2}\left|\left(t_{p \cdot u}-\tau_{p \cdot u}\right)-\left(t_{p \cdot n}-\tau_{p \cdot n}\right)\right|,
$$

ここと, 複号は $\kappa<1$ のとき,$+ n>1$ のとき—とする。

さら飞, $r_{t}$ は伝播速度の比であるから，

$$
\left(t_{p \cdot u}-\tau_{p \cdot u}\right) /\left(t_{p \cdot n}-\tau_{p \cdot n}\right)=1 / r_{t}
$$

の関係があり，これを(8.5) 式火入れると，

$$
\phi=\frac{1}{2}\left(t_{p \cdot n}-\tau_{p \cdot n}\right)\left(1 / r_{t}-1\right)=\frac{1}{2}\left(t_{p \cdot u}-\tau_{p \cdot u}\right)\left(1-r_{t}\right)
$$

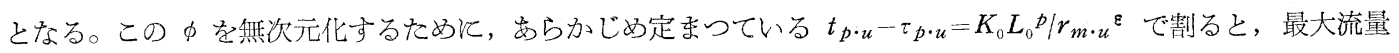
の発生時刻の䛊差表現として,

$$
\psi=\left(r_{m \cdot u^{\varepsilon}} / K_{0} L_{0}{ }^{p}\right) \phi=\left(1-\gamma_{t}\right) / 2
$$

が光られる。したがつて， $r_{t}=1$ のときに $\psi=0$ となり，また そ一定とするとき， $K_{0}, L_{0}$ の増加が $\phi$ を增加

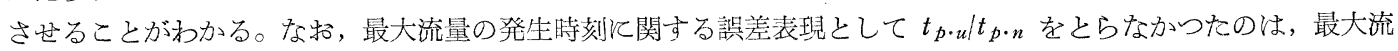

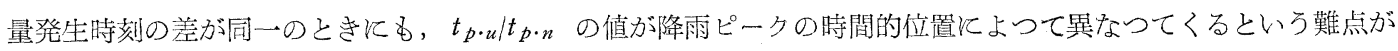
あるからである。 
図-8.2 降雨累加曲線亡雨水擾乱の出発お よび到達時刻との関係

Fig. 8.2 Relation between rainfall mass curve and starting and reaching times of rainfall disturbance

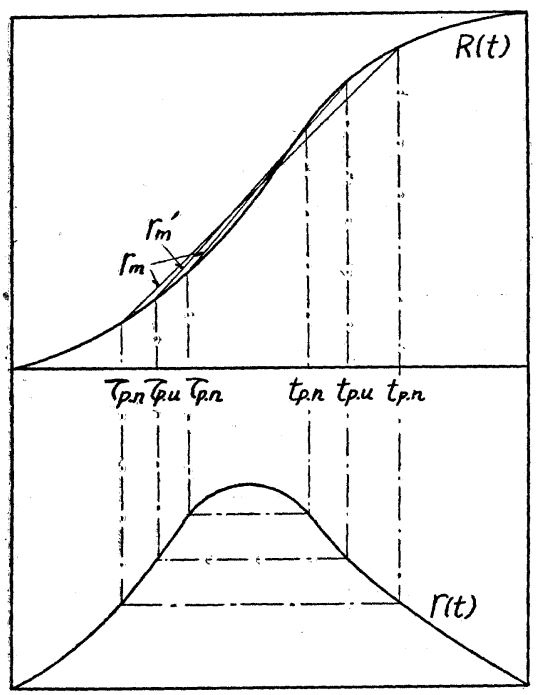

つぎに, 最大流量の誤差について考えよう。平均強度 $r_{m}$ の降雨 による最大流量 $Q_{n \cdot p}$ は，(5.8) 式から，

$$
Q_{n \cdot p}=\left\{\left(\alpha_{q p}\right)_{m \cdot n} / K_{0}{ }^{1 / p}\right\} \int_{\tau, n}^{t_{p \cdot n}} r(t) d t
$$

と表わされる。一方, 平均強度 $r_{m \cdot u}$ の降雨に適合させた単位降雨 $\left(r_{u}, t_{u}\right)$ を用いた単位図法による最大流量 $Q_{u \cdot p}$ は，(5.9) 式飞よ つて,

$$
\begin{aligned}
Q_{u \cdot p} & =\frac{\left(\alpha_{q p}\right)_{m \cdot u}}{K_{0}{ }^{1 / p}}\left\{m_{1} \int_{\tau}^{t_{u_{i=1}}} r_{u} d t+\sum_{i=2}^{i} m_{i} \int_{0}^{t} r_{u} d t\right. \\
& \left.+m_{i+1} \int_{p^{-t} u_{i=i}}^{t} r_{u} d t\right\}=\left\{\left(\alpha_{q p}\right)_{m \cdot u} / K_{0}{ }^{1 / p}\right\} \int_{\tau}^{t}{ }_{j \cdot u}^{t} r(t) d t
\end{aligned}
$$

となる。したがつて, 単位図法による最大流量と実際のとれとの相 対愦差 $r_{Q}$ W,

$$
\begin{aligned}
& r_{Q}=\frac{Q_{u \cdot p}}{Q_{n \cdot p}}=\frac{\left(\alpha_{q p}\right)_{m \cdot u}}{\left(\alpha_{q p}\right)_{m \cdot n}} \int_{\tau_{p \cdot u}}^{t_{p \cdot u}} r(t) d t / \int_{\tau_{p \cdot n}}^{t} r \cdot n \\
& =\kappa \frac{\left(t_{p \cdot u}-\tau_{p \cdot u}\right)}{\left(t_{p \cdot n}-\tau_{p \cdot n}\right)} \frac{r_{m}{ }^{\prime}}{r_{m}}=\frac{r_{m}{ }^{\prime}}{r_{m}}, \\
& \text { ここ注, } \quad r_{m}{ }^{\prime}=\int_{\tau_{p \cdot u}}^{t_{p \cdot u}} r(t) d t / \int_{\tau p \cdot u}^{t_{p \cdot u}} d t, \\
& r_{m}=\int_{\tau \cdot n}^{t}{ }_{p \cdot n} r(t) d t / \int_{\tau \cdot n}^{t} d t .
\end{aligned}
$$

ところがさきに述べそところから，最大流量の伝播時間 $\left(t_{p \cdot u}-\tau_{p \cdot u}\right)$ は $r_{m \cdot u}$ につて定まつているものであ り, $r_{m}=r_{m \cdot u}$ のときには $\left(t_{p \cdot u}-\tau_{p \cdot u}\right)=\left(t_{p \cdot n}-\tau_{p \cdot n}\right)$ であるから $r_{Q}=1$, すなわち単位図法による最大流量の愦 差が 0 となるのは当然である。

さて，最大流量を発生する $\tau_{p}$ と $t_{p}$ の間には，r $\left(\tau_{p}\right)=r\left(t_{p}\right)$ の条件があるから，r $(t)$ が一定でないかぎり， $\left(t_{p}-\tau_{p}\right)$ の増加につれて $r\left(\tau_{p}\right)$ 特よび $r\left(t_{p}\right)$ が減少し, $\left(t_{p}-\tau_{p}\right)$ が減少するとさ $r\left(\tau_{p}\right)$ 特よび $r\left(t_{p}\right)$ が増加 する。したがつて,

$$
\left.\begin{array}{l}
r_{m}>r_{m \cdot u} \rightarrow t_{p \cdot n}-\tau_{p \cdot n}<t_{p \cdot u}-\tau_{p \cdot u} \rightarrow r_{m}>r_{m}{ }^{\prime} \rightarrow r_{Q}<1, \\
r_{m}<r_{m \cdot u} \rightarrow t_{p \cdot n}-\tau_{p \cdot n}>t_{p \cdot u}-\tau_{p \cdot u} \rightarrow r_{m}<r_{m}{ }^{\prime} \rightarrow r_{Q}>1
\end{array}\right\}
$$

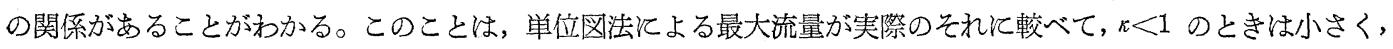
x>1 のときは大きいことを意味する。

(8.8) 式のままではわかりにくいので, さらに以下のように変形しよう。すなわち, 最大流量の発生時刻の誤

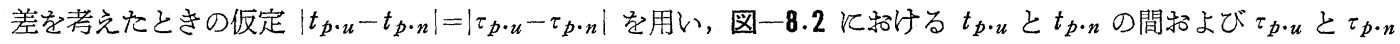
の間で降雨強度がそれぞれ一定值 $r\left(t_{p \cdot n}\right)$ 括よび $r\left(\tau_{p \cdot n}\right)$ であると近似し, 最大流量の発生条件から $r\left(\tau_{p \cdot n}\right)=$ $r\left(t_{p \cdot n}\right)$ が成立することを考慮すると,

$$
r_{m}^{\prime}=\frac{r_{m}\left(t_{p \cdot n}-\tau_{p \cdot n}\right)}{t_{p \cdot u}-\tau_{p \cdot u}} \pm \frac{2 r\left(t_{p \cdot n}\right)\left|t_{p \cdot u}-t_{p \cdot n}\right|}{t_{p \cdot u}-\tau_{p \cdot u}}
$$

がえられる。ここに，複号は $\kappa<1$ のとき+， $\kappa>1$ のときーとする。したがつて，(8.8）式から

$$
\left.\begin{array}{rl}
r_{Q} & =\frac{r_{m}^{\prime}}{r_{m}}=\frac{t_{p \cdot n}-\tau_{p \cdot n}}{t_{p \cdot u}-\tau_{p \cdot u}}+\frac{2 r\left(t_{p \cdot n}\right)}{r_{m}} \frac{t_{p \cdot u}-t_{p \cdot n}}{t_{p \cdot u}-\tau_{p \cdot u}} \\
& =r_{t}+2 \nu \psi=r_{t}+\nu\left(1-r_{t}\right), \text { ただし } \nu=r\left(t_{p \cdot n}\right) / r_{m} \leqq 1
\end{array}\right\}
$$

となる。これから容易に $\left|1-r_{Q}\right| \leqq\left|1-r_{t}\right|$ の関係が導かれるから, 最大流量の相対誤差の1からのずれは, 伝播 飞関するるのより小さいことがわかる。しかし奏際に核請差の性格と絶対量とが間題になるから，単位図法の欠 点が最大流量の合致度より伝播時間のとれにあるとは断定するわけにいかない。たとえば $r_{t}=0.9, \nu=0.5$ の場合 を考皇ると, (8.11) 式から当然 $r_{Q}=0.95$ となるが, (8.6) 式から最大流量の発生時刻の差は,

$$
\phi=\frac{1}{2}\left(t_{p \cdot n}-\tau_{p \cdot n}\right)(1 / 0.9-1)=\frac{1}{18}\left(t_{p \cdot n}-\tau_{p \cdot n}\right)
$$

となり，また最大流量そのものの差は,

$$
Q_{u \cdot p}-Q_{n \cdot p}=Q_{n \cdot p}\left(r_{Q}-1\right)=-0.05 Q_{n \cdot p}
$$

となる。実際の出水現象に括けるオーダーを考光て, $t_{p \cdot n}-\tau_{p \cdot n}=9 \mathrm{hr}, Q_{n \cdot p}=2000 \mathrm{~m}^{3} / \mathrm{s}$ とすれば， 
$\phi=0.5 \mathrm{hr}, \quad Q_{u \cdot p}-Q_{n \cdot p}=-100 \mathrm{~m}^{3} / \mathrm{s}$

となつて, この場合最大流量の発生時刻の誤差よりも最大流量そのるのの誤差が問題となるであろう。このよう に誤差論的には伝播時間の方が問題になるはずであるが，出水解析といろ実際上の立場からは，最大流量の合致 度を注目することで必要がある。

さて, 降雨強度が一定のときは $r_{m}=r\left(t_{p \cdot n}\right)$, すなわち $\nu=1$ となり，(8.6) 式によつて最大流量の発生時刻は 変化するが，最大流量そのものの誤差は０となる。しかし一般にはレは1よりかなり小さいから，安全側を考兄 ると，(8.11) 式の右辺第 2 項を無視してつぎのようにできよう。

$r_{Q} \fallingdotseq r_{t}$

図一8.3 $\sigma_{Q}$ と $\boldsymbol{x}$ および $\nu$ との関係

Fig. 8.3 Relation between $\sigma_{Q}$ and $\kappa, \nu$

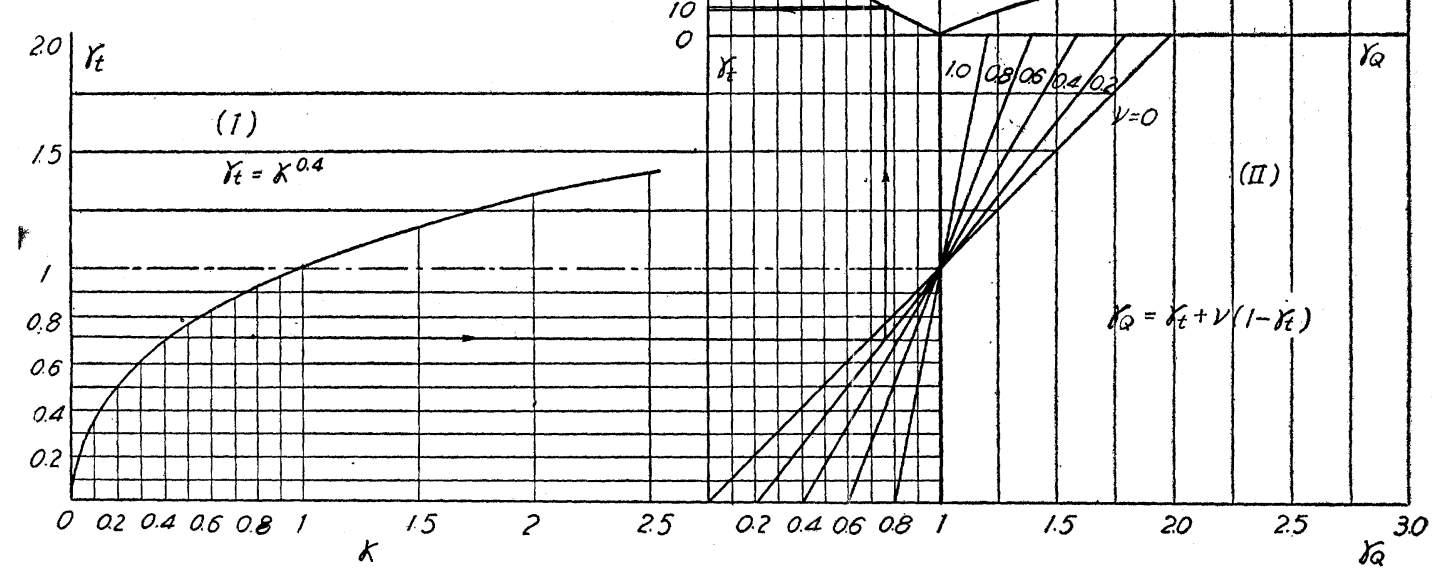

レは降雨の時間的変動を示すパラメーターであつて, 変動が少ない症どレは1亿近づくから，rQ もまた 1 亿近 づく。すなわち, 単位図法の精度は降雨曲線が扁平になるにつれて増加することがわかる。

いま，最大流量の誤差 $\sigma_{Q}$ として，

$$
\left.\begin{array}{l}
r_{Q}<1 ; \quad \sigma_{Q}=1-r_{Q}=(1-\nu)\left(1-r_{t}\right), \\
r_{Q}>1 ; \quad \sigma_{Q}=1-1 / r_{Q}=1-1 /\left\{r_{t}+\nu\left(1-r_{t}\right)\right\}
\end{array}\right\} \cdots
$$

と表わすことにする。この意味は $\sigma_{t(q)}$ の場合と同様であつて， $\gamma_{t}$ と $\kappa$ の間に $(8.2)$ 式の関係があるから, (8. 13) 式を図示すれば 図一8.3 のようになる。図格いてIは (8.2) 式から，IIはをパラメーターとして(8.11) 式から,さらに III (8.13) 式から画いたすのである。この図から最大流量に関する誤差を求めるには, まず矢

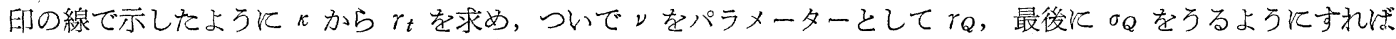
よい。逆に $r_{Q}$ をる ％以下ときめた場合に, 単位図法適用可能の $r_{m}$ の上限值执よび下限值を求めるには, さ きの矢印の線を逆にたでればよい。

以上の関係を，さらに解析的炕表現しょう。まず (8.13) 式の上式から $r_{t}=1-\sigma_{Q} /(1-\nu)$ であるから， $r_{m} の$ 上限値 $r_{m}^{\prime}$ は,

$$
r_{m}^{\prime}=r_{m \cdot u} /\left\{1-\sigma_{Q} /(1-\nu)\right\}^{1 / \varepsilon}
$$

として与兄らる。また (8.13) 式の下式から $r_{t}=\left\{1-\nu\left(1-\sigma_{Q}\right)\right\} /\left\{(1-\nu)\left(1-\sigma_{Q}\right)\right\}$ であるから， $r_{m}$ の下限値 $r_{m}{ }^{\prime \prime}$ はつぎのようКなる。

$$
r_{m}^{\prime \prime}=r_{m \cdot u}\left[(1-\nu)\left(1-\sigma_{Q}\right) /\left\{1-\nu\left(1-\sigma_{Q}\right)\right\}\right]^{1 / \varepsilon} .
$$

いま,一例として $\sigma_{Q}=10 \%, \nu=0.5$ とすれば, $\varepsilon=0.4$ であるから，

$$
r_{m}{ }^{\prime}=1.75 r_{m \cdot u}, \quad r_{m}{ }^{\prime \prime}=0.35 r_{m \cdot u}
$$

となる。したがつてこの条件下では, 単位図の基礎として選し泡降雨強度 $r_{m} \cdot u$ の $0.35 \sim 1.75$ 倍の範囲の $r_{m} の$ 降雨飞対して，単位図法を適用してよいことになる。 


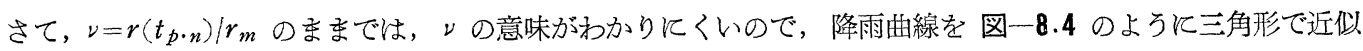

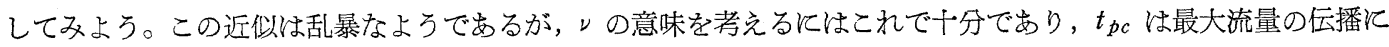
要する時間, $r_{p}$ は最大降雨強度である。この場合は 図-8.4 から明らかなようと，

\section{図一8.4עの意味を説明する三角形状降雨曲線}

Fig. 8.4 Triangular model distribution of rainfall illustrating the meaning of $\nu$

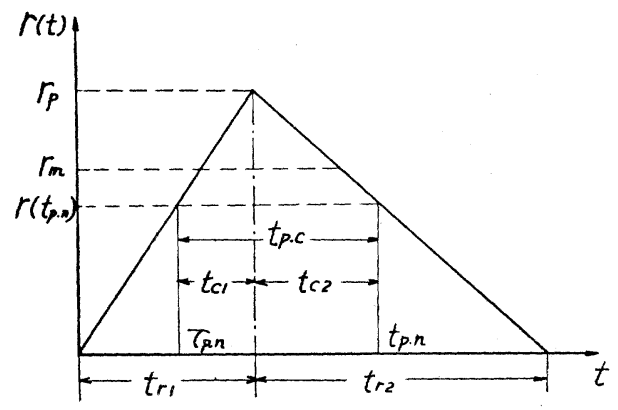

$$
\begin{aligned}
& r_{m}=\left\{r_{p}+r\left(t_{p \cdot n}\right)\right\} / 2, \ldots \ldots \ldots \ldots \ldots \ldots \ldots \ldots \ldots \\
& r\left(t_{p \cdot n}\right)=r_{p} \tau_{p \cdot n} / t_{r 1}=r_{p}\left(t_{r_{1}}-t_{c 1}\right) / t_{r_{1}}
\end{aligned}
$$

となる。さらと相似の条件から

$$
t_{r_{1}}+t_{r_{2}}=t_{d}, \quad t_{c 1}=t_{r_{1}} t_{p c} / t_{d}
$$

となり，これを(8.17) 式と代入すると，

$$
r\left(t_{p \cdot n}\right)=r_{p}\left(1-t_{p c} / t_{d}\right)
$$

したがつて，これと（8.16）式とから，つぎのようにレが $t_{p c}$ と $t_{d}$ とによつて表現される。

$$
\nu=r\left(t_{p \cdot n}\right) / r_{m}=2\left(t_{d}-t_{p c}\right) /\left(2 t_{d}-t_{p c}\right)
$$

ところが $t_{d}$ は降雨記録から直らに求められ， $t_{p c}$ は 2.(2) (c) に述べた最大流量発生条件を基礎とした簡易推算法によ ればよい。こうして $t_{d}, t_{p c}$ がわかると, 各降雨について

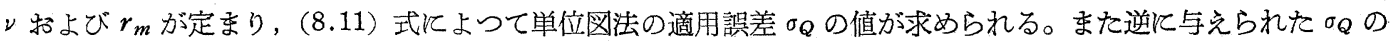
值に対応する降雨強度 $r_{m}$ の適用範囲が, 図一8.3 あるいは $(8.14),(8,15)$ 式から求められる。

要するに一流域に括ける単位図法の適用限界を考えるときでる，降雨強度のみでなく，その時間的分布を考慮 することが必要になる。したがつて，わが国のような小流域に特ける単位図法の適用限界の問題には，流域特性 $B_{c}$, 降雨の平均強度 $r_{m}$ 抽よびその時間的変動を示すパラメーターレの三つの因子が含まれることになり, 小流 域泟ける単位図法の適用を困難かつ複雑にする理由が明らかになつたといえよう。

（b）大流域の場合 $\left(\left(\boldsymbol{t}_{u}<\boldsymbol{t}_{c}, \boldsymbol{t}_{d}<\boldsymbol{t}_{c}\right)\right.$ 6.(2) で述べたように, 単位降雨括よび対象降雨からの $\left(\alpha_{t p}\right)_{m}$ はと れぞれ (6.1) 式括よび (6.12) 式で与えられ，伝播時間の相対誤差 $r_{t}$ は，

$$
r_{t}=\frac{\left(\alpha_{t p}\right)_{m \cdot u}}{\left(\alpha_{t p}\right)_{m \cdot n}}=\left(\frac{B_{c}+\varepsilon r_{m} \delta t_{d} \delta+1}{B_{c}+\varepsilon r_{u} \delta t_{u} \delta+1}\right)\left(\frac{r_{u} t_{u}}{r_{m} t_{d}}\right)^{\delta}
$$

となる。ところが $r_{u}, t_{u}$ はある特定の降雨の平均強度 $r_{m \cdot u}$ と継続時間 $t_{d \cdot u}$ 飞対して妥当なるのであつて, と の関係は (6.14) 式から $r_{u} t_{u}=r_{m \cdot u} t_{d \cdot u}$ となるから，これを (8.19) 式代入し，かつ $B_{c} \gg \varepsilon r_{m} \delta t_{d} \delta+1, B_{c} \gg$ $\varepsilon r_{u}{ }^{\delta} t_{u}{ }^{\delta+1}$ なることを考慮すると, 結局つぎの関係がえられる。

$$
r_{t}=\left(r_{m \cdot u} t_{d \cdot u} / r_{m} t_{d}\right)^{\delta}=\left(R_{u} / R_{t d}\right)^{\delta}=\mu^{\delta} .
$$

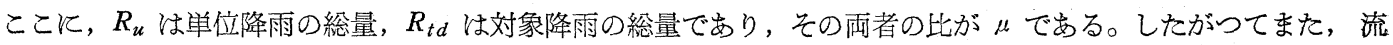
量の係数 $\left(\alpha_{q p}\right)_{m}$ の相対誤差 $r_{q}$ \&, 次式で与学られる。

$$
r_{q}=\left(\alpha_{q p}\right)_{m \cdot u} /\left(\alpha_{q p}\right)_{m \cdot n}=\mu \delta \text {. }
$$

これらから最大流量の伝播時間肪よび流量の係数に関する相対誤差 $r_{t}, r_{q}$ は, ともに $\mu=R_{u} / R_{t d}$ のほぼ $2 / 3$ 乗であることがわかる。そこで $\delta=2 / 3$ として，

$$
\left.\begin{array}{ll}
\mu<1 ; & \sigma_{t(q)}=1-\gamma_{t(q)}=1-\mu^{2 / 3}, \\
\mu>1 ; & \sigma_{t(q)}=1-1 / \gamma_{t(q)}=1-1 / \mu^{2 / 3}
\end{array}\right\}
$$

を与兄て拉けば，最大流量の伝播時間（発生時刻）括よび流量の係数の諆差を表わすことができる。図一8.5 は

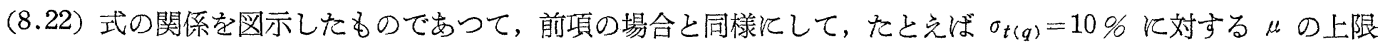
值は 1.2 , 下限值は 0.85 となり, これから $R_{t d}$ の適用範囲が求められる。

つぎに最大流量については， $Q_{p}=\left\{\left(\alpha_{q p}\right)_{m} / K_{0}{ }^{1 / p}\right\} \int_{0}^{t} r(t) d t$ であるから，その相対誤差 $r_{Q}$ は前項の場合と 同様にして,

$$
r_{Q}=\frac{Q_{u \cdot p}}{Q_{n \cdot p}}=\frac{\left(\alpha_{q p}\right)_{m \cdot u}}{\left(\alpha_{q p}\right)_{m \cdot n}} \int_{0}^{t_{d}} r(t) d t / \int_{0}^{t} r(t) d t=\mu \delta .
$$

となる。したがつて, 䛊差 $\sigma_{Q}$ としては, $\mu=2 / 3$ とおいて，

$$
\left.\begin{array}{ll}
\mu<1: & \sigma_{Q}=1-r_{Q}=1-\mu^{2 / 3}, \\
\mu>1: & \sigma_{Q}=1-1 / r_{Q}=1-1 / \mu^{2 / 3}
\end{array}\right\}
$$

と表わせばよい。これを図示すれば， $\sigma_{Q}=\sigma_{t(q)}$ であるから 図一8.5 のようであつて，これから鿁差 $\sigma_{Q}$ に対応す

* この場合は小流域の場合と異なつて常に $\tau_{p}=0$ であるから，伝播時間についての $r_{t}$ を, 最大流量の発生時 刻についてのものとして差支えない。 
図一8.5 $\sigma_{t}$ および $\sigma_{Q}$ と $\mu$ との関係

Fig. 8.5 Relation between $\sigma_{t}, \sigma_{Q}$ and $\mu$

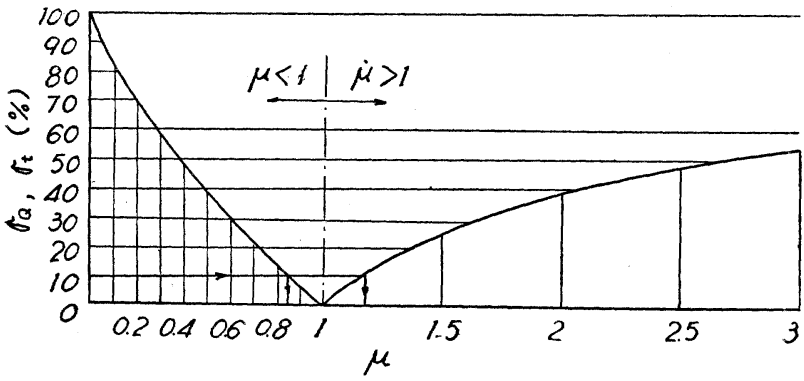

る $\mu$ の上, 下限値, すなわち $R_{t d}$ の適用範 囲が求められる。

以上の考察からわかるようと，大流域飞招 ける単位図法適用限界飞ついては, 総雨量だ けを考えればよく，前項の小流域の場合とい ちじるしく異なつている。このことは，大流

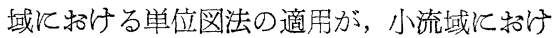
るものに較べて，いか有効であるかを明示 するものである。

\section{（2）流出量曲線全体に関する単位図法誤} 差

前節では流出量曲線のピーク 付近の単位図法誤差について考察したが，その成果を流出過程の全体とあてはめ ることができないのは，流出機構すなわち $\alpha_{t}$ の表示が時間区分によつて異なることから当然とい方よう。とれ でここでは, 単位図法によつて最大流量を合致させることができ炕単位降雨 $\left(r_{u}, t_{u}\right)$ からの単位図を，流出過程 の全体にわたつて適用した場合の愦差について，考察を進めることとする。

（a）小流域の場合 $\left(\boldsymbol{t}_{u}<\boldsymbol{t}_{c}, \boldsymbol{t}_{d}>\boldsymbol{t}_{c}\right)$. この場合の流出機構を模型的に画くと 図一8.6 のと招りであつて,前節 (a)で述べたことは $t_{c} \leqq t \leqq t_{d}$ の区間についてあてはまり，ピークがこの区間内にくることはいうまでるない。

\section{図一8.6 $\boldsymbol{t}_{u}<\boldsymbol{t}_{c}, \boldsymbol{t}_{d}>\boldsymbol{t}_{c}$ の場合の流出機構}

Fig. 8.6 Runoff mechanism in the case of $t_{u}<t_{c}$ and $t_{d}>t_{c}$

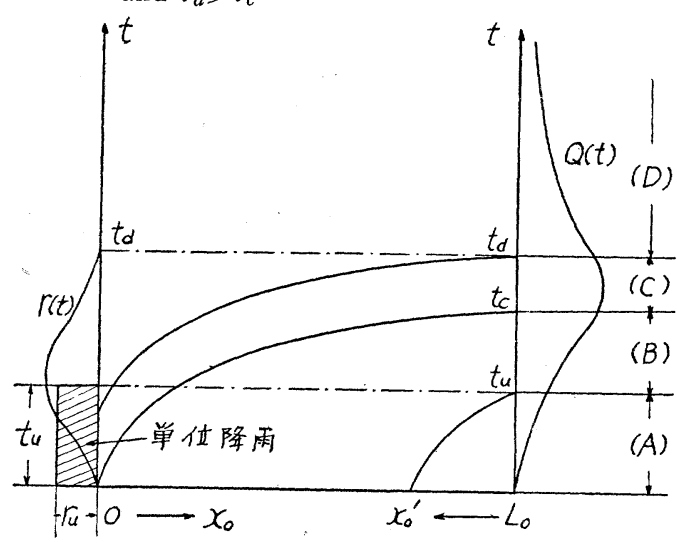
$\alpha_{t}$ の表示の差異によつて流出機構を分類すると，
(A) $0 \leqq t<t_{u}$,
(B) $t_{u} \leqq t<t_{c}$,
(C) $t_{c} \leqq t<t_{d}$
(D) $t_{d} \leqq t$

とするこにができるから，以下にそれ先れの区分の誤差に ついて述べよう。

(A) $0 \leqq t<t_{u}: B_{c}$ 中の $L_{0}$ を下流端から上流端飞向つ て，測つた距離 $x_{0}^{\prime}$ で标きかえたものを $B_{c}^{\prime}$ とすると， (5.6) 式加,

$$
\begin{aligned}
& \left(\alpha_{t}\right)_{m \cdot u}=p^{p} B_{c}{ }^{\prime} \varepsilon r_{u}{ }^{\varepsilon},\left(\alpha_{t}\right)_{m \cdot n}=p^{p} B_{c}{ }^{8} r_{m}{ }^{\varepsilon}, \\
& \therefore r_{t}=\left(\alpha_{t}\right)_{m \cdot u} /\left(\alpha_{t}\right)_{m \cdot n}=\left(r_{u} / r_{m}\right)^{\varepsilon}
\end{aligned}
$$

となる。これと $r_{u}$ として (6.6) 式の関係を入れると,

$$
r_{t}=\left(p^{p^{2}} B_{c}^{\varepsilon} p / t_{u}^{\varepsilon}\right)\left(r_{m \cdot u^{p}} / r_{m}\right)^{\varepsilon}
$$

となる。いま，単位図法による流量和よび実際の流量をそ れぞれ $Q_{u}, Q_{n}$ とすれば,

$$
Q_{u}=\frac{\left(\alpha_{q}\right)_{m \cdot u}}{K_{0}^{1 / p}} \frac{\int_{0}^{t^{1}{ }^{1}} r(t) d t}{\int_{0}^{t^{t} u} r_{u} d t} \int_{0}^{t} r_{u} d t=\frac{\left(\alpha_{q}\right)_{m \cdot u}}{K_{0}^{1 / p}} \int_{0}^{t} r_{m}{ }^{\prime} d t,
$$

$$
Q_{n} \fallingdotseq \frac{\left(\alpha_{q}\right)_{m \cdot n}}{K_{0}^{1 / p}} \int_{0}^{t} r_{m} d t
$$

となる。したがつて，つぎの関係がえられる。

$$
\begin{gathered}
r_{Q}=Q_{u} / Q_{n} \fallingdotseq r_{t} r_{m}{ }^{\prime} / r_{m}, \\
\text { ここr, } \quad r_{m}^{\prime}=\int_{0}^{t_{u}} r(t) d t / \int_{0}^{t_{u}} d t, r_{m}=\int_{0}^{t} r(t) d t / \int_{0}^{t} d t .
\end{gathered}
$$

とくに $t_{u}$ があまり大きくなければ， $r_{m}{ }^{\prime} \fallingdotseq r_{m}$ と近似できるから， $p=0.6$ と和いて，

$$
r_{Q} \doteqdot r_{t}=\left(0.6^{0.36} B_{c}{ }^{0.24} / t_{u}{ }^{0.4}\right)\left(r_{m} \cdot u^{0.6} / r_{m}\right)^{0.4}
$$

としてよい。さらと小流域では上式右辺の第 1 括弧はほぼ1であるから，rQの大略の值としては，

$$
\gamma_{Q}=\left(r_{m \cdot u} u^{0.6} / r_{m}\right)^{0.4}
$$

と表わしてよいであろう。

(B) $t_{u} \leqq t<t_{c}:(5.7)$ と (5.6) の両式加ら,

$$
\left(\alpha_{t}\right)_{m \cdot u}=B_{c}\left(r_{u} t_{u}\right)^{\delta} /\left\{B_{c}{ }^{\prime}+\varepsilon r_{u}{ }^{\delta} t_{u}^{\delta+1}\right\},\left(\alpha_{t}\right)_{m \cdot n}=p^{p} B_{c}{ }^{\prime \varepsilon} r_{m}{ }^{\varepsilon}
$$

となる。この此をとり， $r_{u}$ として (6.6) 式を入れると，

$$
r_{t}=\left(\alpha_{t}\right)_{m \cdot u} /\left(\alpha_{t}\right)_{m \cdot n} \fallingdotseq\left(B_{c} / B_{c}{ }^{\prime}\right)^{\varepsilon}\left(r_{m \cdot u} \mid r_{m}\right)^{\varepsilon}
$$


となる。また

$$
\begin{aligned}
Q_{u} & \fallingdotseq\left\{\left(\alpha_{q}\right)_{m \cdot u} \mid K_{0}^{1 / p}\right\}\left\{\sum_{i=0}^{i} m_{i} \int_{0}^{t_{u} u} r_{u} d t+m_{i+1} \int_{0}^{t-i t} u r_{u} d t\right. \\
& \fallingdotseq\left\{\left(\alpha_{q}\right)_{m \cdot u} \mid K_{0}{ }^{1 / p}\right\} \int_{0}^{t} r_{m} d t, \\
Q_{n} & \fallingdotseq\left\{\left(\alpha_{q}\right)_{m \cdot n} / K_{0}^{1 / p}\right\} \int_{0}^{t} r_{m} d t,
\end{aligned}
$$

ここ纤, 番号 $i$ は $i t_{u}<t<(i+1) t_{u}$ を满足するすのであり,

$$
m_{i}=\left[\int_{0}^{t_{u}} r(t) d t\right]_{i} / \int_{0}^{t_{u}} r_{u} d t, \quad r_{m}=\int_{0}^{t} r(t) d t / \int_{0}^{t} d t
$$

である。したがつて， $\varepsilon=0.4$ と报くと，

$$
r_{Q}=Q_{u} / Q_{n}=r_{t}=\left(B_{c} / B_{c}\right)^{0.4}\left(r_{m \cdot u} \mid r_{m}\right)^{0.4}
$$

となる。ところが $B_{c}>B_{c}{ }^{\prime}$ であり, また一般に $r_{m \cdot u}>r_{m}$ であるから, 単位図法による流量は実際の流量よりる 大きくなり，その相対誤差は $B_{c}{ }^{\prime}$ が小さいほど，すなわち $t$ が $t_{u}$ に近いほど大きく，また $B_{c}{ }^{\prime}$ が $B_{c}$ に近ら゙ くほど,すなわち $t$ が $t_{c}$ に近いほど小さくなつてくる。

(C) $t_{c} \leqq t<t_{d}:$ この区間と括ける $\left(\alpha_{t}\right)_{m}$ の表示は, 前節（a) で取り扱つたすのと同様であるから，

$$
r_{t}=\left(r_{m \cdot u} / r_{m}\right)^{\varepsilon}, \text { ただし } r_{m}=\int_{\tau}^{t} r(t) d t / \int_{\tau}^{t} d t
$$

である。また $r_{Q}$ そついては, 同一時間 $t$ そついての相対誤差であるから,つぎのように表わされる。

$$
r_{Q}=\frac{\left(\alpha_{q}\right)_{m \cdot u}}{\left(\alpha_{q}\right)_{m \cdot n}} \int_{\tau_{n}}^{t} r(t) d t / \int_{\tau_{n}}^{t} r(t) s t=r_{t} \int_{\tau_{u}}^{t} r(t) d t / \int_{\tau_{n}}^{t} r(t) d t,
$$

ここに, $\tau_{u}$ は単位降雨の伝播の出発時刻であつて, $t-\tau_{u}=t_{p \cdot u}-\tau_{p \cdot u}$ であり, また $\tau_{n}$ は対象降雨の伝播の出発 時刻であるから，

$$
r t \lessgtr 1 \text { そ応じて, } \int_{\tau_{u}}^{t} r(t) d t / \int_{\tau_{n}}^{t} r(t) d t \gtrless 1
$$

となる。したがつて, $\left|1-r_{Q}\right| \leqq\left|1-r_{t}\right|$ であつて, 流量に関する相対誤差の1からのずれは一般と伝播時間のそれ より小さいが, $\tau_{u} \fallingdotseq \tau_{n}$ であるから, $\varepsilon=0.4$ と括いて,

$$
r_{Q} \fallingdotseq r_{t}=\left(r_{m \cdot u} / r_{m}\right)^{0.4}
$$

とすれば安全側である。

(D) $t_{d} \leqq t:(5.7)$ 式加

$$
\begin{aligned}
& \left(\alpha_{t}\right)_{m \cdot u}=B_{c}\left(r_{u} t_{u}\right)^{\delta} /\left\{B_{c}+\varepsilon r_{u} \delta t_{u} \delta+1\right\}, \\
& \left(\alpha_{t}\right)_{m \cdot n}=B_{c}\left\{r_{m}\left(t_{d}-\tau\right)\right\}^{\delta} /\left\{B_{c}+\varepsilon r_{m} \delta\left(t_{d}-\tau\right)^{\delta+1}\right\}
\end{aligned}
$$

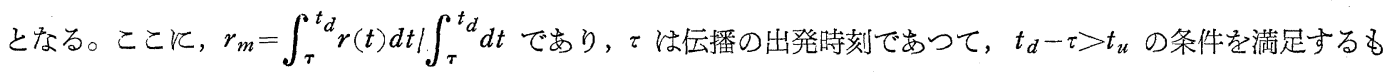
のである。 $t_{d}-\tau \leqq t_{u}$ 区間の $\tau$ から出発するるのは， $t_{u}$ が小さいから問題とするとあたらないかけである。上の 二つの式の比をとり, (6.6) 式の $r_{u}$ を入れると,

$$
r_{t}=\frac{p^{p}}{B_{c}^{1-\varepsilon}} \frac{B_{c}+\varepsilon r_{m} \delta\left(t_{d}-\tau\right)^{\delta+1}}{\left(t_{d}-\tau\right)^{\delta}} \frac{r_{m \cdot u} \varepsilon}{r_{m}^{\delta}} \fallingdotseq \frac{p^{p} B_{c} \varepsilon}{\left(t_{d}-\tau\right)^{\delta}} \frac{r_{m \cdot u} \varepsilon}{r_{m}^{\delta}}
$$

となる。つぎル

$$
\begin{aligned}
& Q_{u} \fallingdotseq\left\{\left(\alpha_{q}\right)_{m \cdot u} \mid K_{0}^{1 / p}\right\} \int_{\tau}^{t_{d}} r(t) d t, \\
& Q_{n}=\left\{\left(\alpha_{q}\right)_{m \cdot n} \mid K_{0}^{1 / p}\right\} \int_{\tau}^{t^{d}} r(t) d t
\end{aligned}
$$

であるから， $p=0.6, \varepsilon=0.4$ と括いて，次式が党られる。

$$
r_{Q}=Q_{u} / Q_{n} \fallingdotseq r_{t} \fallingdotseq\left\{0.6^{0.6} B_{c}^{0.4} /\left(t_{d}-\tau\right)^{2 / 3}\right\}\left(r_{m \cdot u^{0.4}} / r_{m^{2 / 3}}\right)
$$

これからての増加, すなわち流出量曲線の後部の方で誤差が増加することがわかるが, 誤差の絶対量はかなり 小さいから, 問題とする汪どのことはない。な秥， $B_{c}{ }^{0.4}$ は 10 以内であるから，rQ も,大きい俱りはないであろう。

$$
r_{Q}=r_{m \cdot u^{0.4}} / r_{m^{2 / 3}}=\left(r_{m \cdot u} / r_{m^{5 / 3}}\right)^{0.4}
$$

以上を要するに，各時間区分について笚位図法による流量と実際のそれとの相対誤差 $r_{Q}$ を求めたが，これら は流出量曲線のピークを単位図法で合致させた単位降雨 $\left(r_{u}, t_{u}\right)$ からの単位図を用いた場合のもので, いずれも 1からのずれがそれほど大きくないととがわかる。またピーク付近の区間 (C) に較べて，(A)，(B) 拉よび (D) 


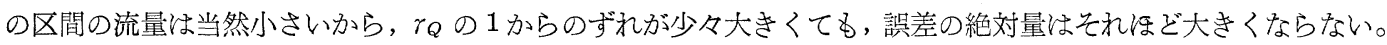
したがつて，単位降雨括よび単位図の要素としては，ピークを合致させるすのに着目し，これを流出過程全体に 適用しても，大した差支觉はないであろう。

（b） 大流域の場合 $\left(\boldsymbol{t}_{u}<\boldsymbol{t}_{c}, \boldsymbol{t}_{d}<\boldsymbol{t}_{c}\right)$ この場合の流出機構を模型的画くと図一8.7 のと拉りであつて， $\alpha_{t}$ の 表示の差異によつて，流出機構をつぎのよろに分類することができる。
(A) $0 \leqq t<t_{u}$,
(B) $t_{u} \leqq t<t_{d}$,
(C) $t_{d} \leqq t<t_{c}$,
(D) $t_{c}<t$

(A) $0 \leqq t<t_{u}:(5.6)$ 式から,

$$
\left(\alpha_{t}\right)_{m \cdot u}=p^{p} B_{c}{ }^{\prime} \varepsilon r_{u}^{\varepsilon},\left(\alpha_{t}\right)_{m \cdot n}=p^{p} B_{c}{ }^{\varepsilon} r_{m}^{\varepsilon}
$$

となるが, $r_{u}, t_{u}$ 流量のピークを合致させるようと定められたもので，(6.14) 式の関係があるから, 結局

$$
r_{t}=\left(\alpha_{t}\right)_{m \cdot u} l\left(\alpha_{t}\right)_{m \cdot n}=\left(t_{d \cdot u} \mid t_{u}\right)^{\varepsilon}\left(r_{m \cdot u} / r_{m}\right)^{\varepsilon}
$$

となる。一方, 流量の相対誤差 $r_{Q}$ は, 前項 (A) と同様にして, つぎのようと表わされる。

$$
\begin{aligned}
& r_{Q}=r_{t}\left(r_{m}{ }^{\prime} / r_{m}\right)=\left(t_{d \cdot u} / t_{u}\right)^{0.4}\left(r_{m \cdot u_{i}} r_{m}\right)^{0.4}\left(r_{m}{ }^{\prime} / r_{m}\right), \\
& \text { ここK, } \quad r_{m}{ }^{\prime}=\int_{0}^{t^{t} u} r(t) d t / \int_{0}^{t} d t, r_{m}=\int_{0}^{t} r(t) d t / \int_{0}^{t} d t
\end{aligned}
$$

(B) $t_{u} \leqq t<t_{d}:(5.7)$ と (5.6) の両式加

$$
\left(\alpha_{t}\right)_{m \cdot u}=B_{c}{ }^{\prime}\left(r_{u} t_{u}\right)^{\delta} /\left\{B_{c}{ }^{\prime}+\varepsilon r_{u} \delta t_{u}{ }^{\delta+1}\right\},\left(\alpha_{t}\right)_{m \cdot n}=p^{p} B_{c}{ }^{\prime} \varepsilon r_{m}^{\varepsilon}
$$

\section{図-8.7 $\boldsymbol{t}_{u}<\boldsymbol{t}_{c}, \boldsymbol{t}_{d}<\boldsymbol{t}_{c}$ の場合の流出機構}

Fig. 8.7 Runoff mechanism in the case of $t_{u}<t_{c}$ and $t_{d}<t_{c}$

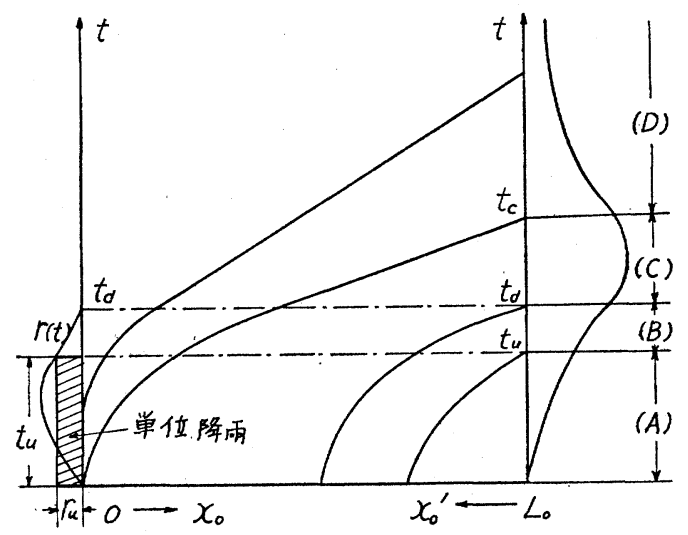

となり，さらに (6.14) 式を考慮すると，

$$
\begin{aligned}
& r_{t}=\frac{B_{c}{ }^{1-\varepsilon}}{p^{p} r_{m}^{\varepsilon}} \frac{\left(\boldsymbol{r}_{m \cdot u} t_{d \cdot u}\right)^{\delta}}{B_{c}{ }^{\prime}+\varepsilon t_{u}\left(r_{m \cdot u} t_{d \cdot u}\right)^{\delta}} \\
& \fallingdotseq \frac{t_{d \cdot u^{\varepsilon}}}{p^{p} B_{c}{ }^{\prime} \varepsilon} \frac{r_{m \cdot u^{\delta}}}{r_{m}^{\varepsilon}}
\end{aligned}
$$

となる。大流域では一般飞 $t_{d \cdot u} \delta \fallingdotseq p^{p} B_{c}{ }^{\prime} \varepsilon$ と近似でき るから， $\gamma_{Q}$ は前項 (B) と同様にして，つぎのように表 わされる。

$$
\left.\begin{array}{c}
r_{Q} \fallingdotseq r_{t} \fallingdotseq r_{m \cdot u^{2 / 3} / r_{m}{ }^{0.4},} \\
\text { ただし, } \quad r_{m}=\int_{0}^{t} r(t) d t / \int_{0}^{t} d t
\end{array}\right\}
$$

(C) $t_{d} \leqq t<t_{c}$ : この区間の $\alpha_{t}$ の表示は, 前節 $(\mathbf{b})$

で取り扱つたと同様であるから，

$$
\left.\begin{array}{l}
r_{Q}=r_{t}=\left(r_{m \cdot u} t_{d \cdot u} \mid r_{m} t_{d}\right)^{2 / 3}, \\
\text { ただし, } \quad r_{m}=\int_{0}^{t_{d}} r(t) d t / \int_{0}^{t_{d}} d t
\end{array}\right\}
$$

となる。

(D) $t_{c} \leqq t:(5.7)$ 式から伝播の出発時刻 $\tau$ 亿応じて,

$$
\begin{aligned}
& t_{d}-\tau \geqq t_{u} \text { のとき, }\left(\alpha_{t}\right)_{m \cdot u}=B_{c}\left(r_{u} t_{u}\right)^{\delta} /\left\{B_{c}+\varepsilon r_{u} \delta t_{u^{\delta+1}}\right\}, \\
& t_{d}-\tau<t_{u} \text { のとき, }\left(\alpha_{t}\right)_{m \cdot u}=B_{c}\left\{r_{u}\left(t_{u}-\tau\right)\right\}^{\delta} /\left\{B_{c}+\varepsilon r_{u} \delta\left(t_{u}-\tau\right)^{\delta+1}\right\}
\end{aligned}
$$

となり, さらに

$$
\left(\alpha_{t}\right)_{m \cdot n}=B_{c}\left\{r_{m}\left(t_{d}-\tau\right)\right\}^{\delta} /\left\{B_{c}+\varepsilon r_{m} \delta\left(t_{d}-\tau\right)^{\delta+1}\right\}
$$

となる。これらと (6.14) 式を用い， $B_{c} \gg \varepsilon r_{u} \delta t_{u}^{\delta+1}, \varepsilon r_{u} \delta\left(t_{u}-\tau\right)^{\delta+1}, \varepsilon r_{m}^{\delta}\left(t_{d}-\tau\right)^{\delta+1}$ なることを考虑すると，

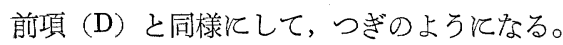

$$
\left.\begin{array}{ll}
t_{d}-\tau \geqq t_{u} ; & r_{Q} \fallingdotseq \gamma_{t} \fallingdotseq\left\{r_{m \cdot u} t_{d \cdot u} \mid r_{m}\left(t_{d}-\tau\right)\right\}^{2 / 3}, \\
t_{d}-\tau<t_{u} ; & r_{Q} \fallingdotseq \gamma_{t} \fallingdotseq\left\{r_{m \cdot u} t_{d \cdot u}\left(t_{u}-\tau\right) / r_{m} t_{u}\left(t_{d}-\tau\right)\right\}^{2 / 3} .
\end{array}\right\}
$$

以上を要するに, 流出量曲線のピークを単位図法で合致させた単位降雨 $\left(r_{u}, t_{u}\right)$ からの単位図を用いた場合飞 ついて，単位図法による流量と実際のそれとの相対誤差 $r_{Q}$ を各時間区分ごとに求めたが，いずれも $r_{Q}$ のから のずれはそれ注ぞ大きくない。また $r_{Q}$ が同一のときは,流量が大きいほど誤差の絶対量が大きくなるはずである。 したがつて，最大流量を合致させた単位降雨，すなおち(6.14) 式で与えられる $r_{u}, t_{u}$ を用いて流出過程全体を 取り扱つても差支觉を生じないであるう。 
前 2 節で述べたように，小流域と大流域とで誤差表現が異なつてくるから，それぞれ添字 $s, l$ をつけて，比較 することにする。まず最大流量とついては, (8.11) と (8.28) の両式から，

$$
\begin{aligned}
& r_{Q \cdot s}=\gamma_{t}+\nu\left(1-\gamma_{t}\right) \fallingdotseq \gamma_{t}=\left(r_{m \cdot u} / r_{m}\right)^{0.4}, \\
& \gamma_{Q \cdot l}=\gamma_{t}=\left(R_{u} / R_{t d}\right)^{2 / 3}
\end{aligned}
$$

と表わされる。したがつて相対誤差は，小流域では単位降雨選定の基礎とした降雨強度 $r_{m} \cdot u$ と最大流量を生じる 対象降雨の平均強度 $r_{m}$ との比の関数であり, また大流域では単位降雨の総量と対象降雨の総量との比の関数でめ る。洪水を対象とする場合, 一般飞

$$
r_{m \cdot u} \mid r_{m} \text { の変動 }>R_{u} \mid R_{t d} \text { の変動 }
$$

である。これは, 洪水を発生する降雨の総量は一流域でそれほで変わるすのでなく, 降雨の時間強度はそのピー ク付近に限つてもいちじるしく変動するからである。したがつて，単位図法による最大流量の誤差は，小流域に 和ける方が大流域に和けるよりる大きいことがわかる。

つぎと流出量曲線全体についての流量の相対誤差 $r_{Q}$ とは, 前節 (a) 特よび (b) の諸式からわかるように, 平 均降雨強度のほかに，小流域では流域特性，大流域では降雨継繶時間が関与する。またいずれの場合にも $r_{m} \cdot u$ と $r_{m}$ の比が入つてくるが,この比の1からのずれは,小流域と大流域のそれぞれに対する $r_{m \cdot u}$ と $r_{m}$ の定義か らわかるように,前者の方が後者より大きいはずである。したがつて, 流出量曲線全体に関する䛊差も, 最大流量

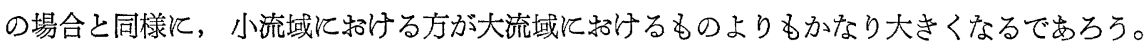

\section{9.むす び}

単位図法が今日に和いても山間地流出を知る最も有効な手段であることから，その適用上の諸問題を解明する ために，古くから多くの研究が行われ，かなりの成果を収めてきたようである。ところが山間地流域に猢る雨 水挙動の極度の複雑さから, これらの研究のほとんどすべてが流出現象を外側からながめるという立場をとつてい て, 経験への依存度が非常に強いから, 工学的な意味での貢献は十分認められても，研究成果湴遍性を欠いて いる点に難点があつた。わが国と米国に和ける単位図法適用に際しての経験的事実の 相違が十分理解できなかつ たのも，従来の研究の立場加は当然とい方よ。

本研究に招いては, 雨水の挙動を全く水理学的な立場から処理し, 単位図法の内蔵する力学的な意義から出発 して，単位降雨あるいは単位図の内部的な機構を明らかてしてから論議を進めたので，えられた成果は本質的に 普遍性をるつているといつて差支えない。

単位図を先験的作成するいわゆる総合単位図の問題あるいは誤差概念を必然的にとるなう 单位図法の適用限 界の問題などは，徒来からその解決が切望されているが，いまだ満足すべき解答が与えられていないようである。 これらの問題を解決するには，まず単位図法のるつ意義を明確に把握しなければならないが，水理学的に一貫し た考察を進めた本研究の成果は，こうした要求にも一つの解答を与えるるのと期待している。

\section{参 考 文 献}

1) B. D. Richard; Flood Estimation and Control, 1950, pp. 1 122.

2) R. T. Zoch; On the Relation between Rainfall and Streamflow, Monthly Weather Rev., Vol. 62, 1932, pp. 315 322 and Vol. 64, 1934, pp. 105 121.

3) H. Jeffreys; The Flow of Water in an Inclined Channel of Rectangular Section, Phil. Mag., Ser. 6, Vol. 49, No. 293, 1925.

4) R.E. Horton, H.R. Leach and R. Van Vliet; Laminar Sheetflow, Trans. Amer. Geophys. Union, Vol. 15, 1934, pp. 393 404

5）岩垣雄一; 雨水流注よる地面浸食機構飞関する基礎的研究, 学位論文, 昭 30.9, pp. 1 32

6) V. J. Palmer; Retardance Coefficients for Low Flow in Channels lined with Vegetation, Trans. Amer. Geophys. Union, Vol. 27, 1946, pp. 187 197.

7) 末石富太郎；特性曲線法汇よる出水解析飞ついて，土木学会論文集，第 29 号，昭 $31.2 ，$ pp. $74 \sim 87$.

8）岩坦雄一, 高棹玩馬; 降雨扔よび流域特性が流出関係飞及ぽす効果とついて, 京大防災研究所創立 5 周年紀 念論文集，昭 31.11, pp. 191 200.

9）岩垣雄一; 特性曲線法による流出の解析について, 土木学会第 12 回年次学術講演会講演概要, 昭 32.6 .

10) F. F. Snyder; Synthetic Unit Hydrographs, Trans. Amer. Geophys. Union, Vol. 19, 1938, pp.447 454 .

11）中安米蔵; 雨量より洪水量の推定飞就て, 建設省直轄工事第四回技術研究報告, 昭 26.3 , pp. 159 194.

12) 立神弘洋; 洪水流出の新解析法, 昭 30.3 , pp. $26 \sim 29$.

13) A. B. Taylor and H. E. Schwarz; Unit-Hydrograph Lag and Peak Flow related to Basin Characteristics, Trans. Amer. Geophys. Union, Vol. 33, 1952, pp. 235 246. 
14）石原藤次郎，田中要三，金丸昭治；わが国飞挌ける単位図の特性について，土木学会誌，第 41 巻,第 3 号, 昭 31.3 , pp. 18 23.

15）石原藤次郎，金丸昭治；降雨条件の変動飞よる単位図の变化飞ついて，土木学会論文集，第 32 号，昭 31.3 , pp. $50 \sim 56$.

昭和 34 年 3 月 1 日 印 刷

昭和 34 年 3 月 5 日 発行 土木学会論文集第 60 号・別冊 (3-3) 定価 150 円（㝏 10 円）

著＼cjkstart者＼cjkstart京都市左京区吉田本町 京都大学土木教室＼cjkstart石原藤次郎・高棹琢馬

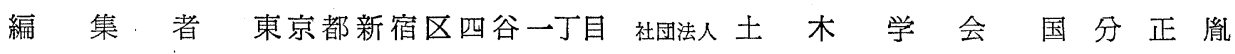

印刷者東京都港区赤坂溜池 5 株式会社技報堂大沼正吉

発 行 所社团土木学 会

東京都新宿区四谷一丁目電話 (35) $5130 \cdot 5138$ • 5139 振替東京 16828 番 